\title{
CONJUGATIVE TRANSFER OF PLASMID pJP4 IN DEFINED BIOFILMS AND CATABOLIC ACTIVITY OF TRANSCONJUGANT CELLS
}

\author{
by \\ Mohammad Borhan Uddin \\ Master of Pharmacy, University of Dhaka, 1997
}

\author{
A thesis \\ presented to Ryerson University \\ in partial fulfillment of the \\ requirements for the degree of \\ Master of Science \\ in the Program of \\ Molecular Science
}

Toronto, Ontario, Canada

(C) Mohammad Borhan Uddin 2014 


\section{AUTHOR'S DECLARATION}

I hereby declare that I am the sole author of this thesis. This is a true copy of the thesis (including any required final revisions, as accepted by my examiners).

I authorize Ryerson University to lend this thesis paper to other institutions or individuals for the purpose of scholarly research.

I further authorize Ryerson University to reproduce this thesis by photocopying or by other means, in total or in part, at the request of other institutions or individuals for the scholarly research purpose.

I understand that my thesis may be made electronically available to the public. 


\title{
CONJUGATIVE TRANSFER OF PLASMID pJP4 IN DEFINED BIOFILMS AND CATABOLIC ACTIVITY OF TRANSCONJUGANT CELLS
}

Mohammad Borhan Uddin

Master of Science, Molecular Science, Ryerson University, 2014

\begin{abstract}
Horizontal gene transfer facilitates the successful exploitation of plasmids and other mobile genetic elements in the bioaugmenation of polluted environments. Biofilms promote plasmid stability and may enhance transfer frequency as well as the host range of mobile genetic elements that are transferred horizontally. In many cases, the conjugative transfer of catabolic genes to recipient cells does not result in a functional phenotype of the plasmid in recipient cells. The functionality of degrading phenotype might depend on the genetic characteristics of transconjugants and environmental conditions. The first objective of this project was to study the conjugative transfer of plasmid pJP4 (which carries genes that encode catabolic functions for the degradation of a herbicide, 2,4dichlorophenoxyacetic acid-2,4-D) in Pseudomonas putida biofilms in the absence of selective pressure. Transconjugant cells were detected microscopically based on their plasmid-conferred red fluorescent protein (DsRed) fluorescence. The results indicated that plasmid pJP4 was transferred from the donor $P$. putida strain to recipient $P$. putida biofilms under non selective pressure condition. The second objective of this study was to investigate 2,4-D degradation capability of a plasmid pJP4 transconjugant strain (isolated from a soil bacterial community) in a batch culture system as well as plasmid stability in the planktonic cultures in the absence of selective pressure. The results showed that the reactor with plasmid pJP4 transconjugant strain contained less than 5\% of the initial concentration $(221 \mathrm{mg} / \mathrm{L})$ of 2,4-D (concentration of 2,4-D was measured spectrophotometrically at $230 \mathrm{~nm}$ ) after 12 days whereas, the reactors with donor $P$. putida SM1443 carrying plasmid pJP4, P. putida ATCC12633, transconjugant strain without a plasmid and a soil microbial community contained $30 \%, 60 \%, 80 \%$ and $37 \%$ of the initial concentration of 2,4-D respectively. The capability of plasmid pJP4 transconjugant strain to maintain its plasmid (plasmid loss rate) in planktonic cultures under non-selective pressure condition was also observed. Plasmid pJP4 was lost from almost 70\% of the transconjugant population within 24 generations (the presence of plasmid in planktonic cultures was detected over time by confocal laser scanning microscopy and spread plate techniques). These observations may be useful for future plasmid pJP4 mediated genetic bioaugmentation studies of polluted environmental samples.
\end{abstract}




\section{ACKNOWLEDGEMENTS}

I would like to thank my supervisor Dr. Martina Hausner, for her great support, inspiration, valuable suggestions and guidance throughout this project. I would like to thank my committee members Dr. Gideon Wolfaardt, Dr. Kimberly Gilbride and Dr. Andrew Laursen (external member of my thesis defense committee) for their valuable inputs and time in developing and finalizing this project. I would also like to acknowledge Mr. Patrick Ronan and Ms. Farhana Shamsad for their help to develop my laboratory skills.

A special thank belongs to my wife Atia Altaf, my back home colleagues, Department of Pharmacy and Board of Governors of North South University, Bangladesh and my parents for their continual support and encouragement. Finally, I would like to acknowledge all the members of the Dr. Hausner, Dr. Wolfaardt and Dr. Gilbride laboratories for their help and suggestions throughout the project.

The source of funding for this project was NSERC. 


\section{Table of Contents}

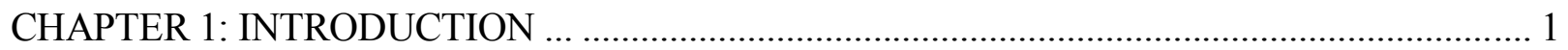

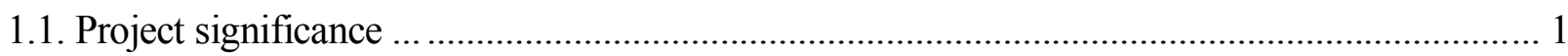

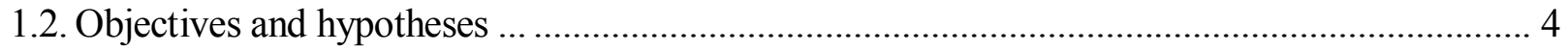

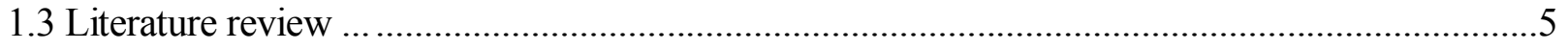

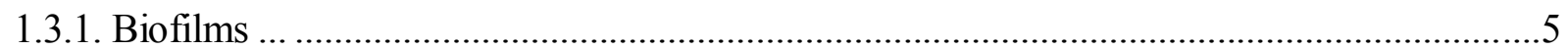

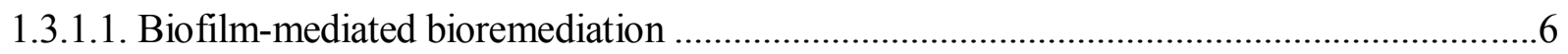

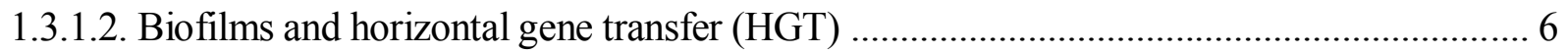

1.3.2. Horizontal gene transfer (HGT)- an advantageous tool to acquire new catabolic pathways

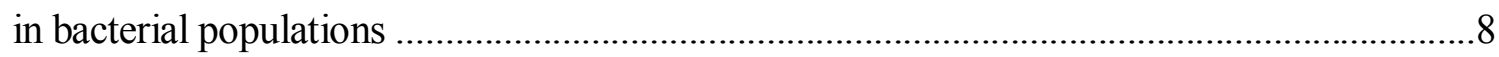

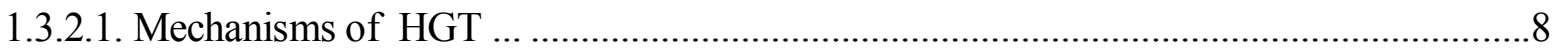

1.3.2.2. Limitations of HGT ….................................................................................... 11

1.3.3. Catabolic mobile genetic elements (MGEs) ............................................................. 11

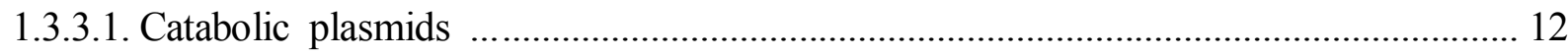

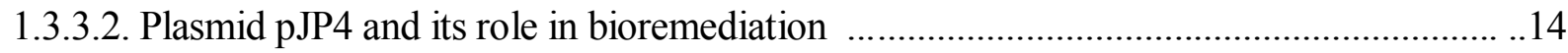

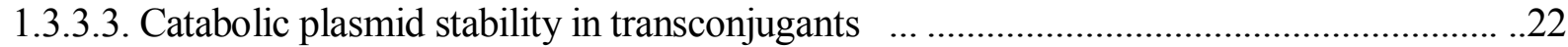

1.3.4. Genetic bioaugmentation -a better strategy of cleaning up environmental

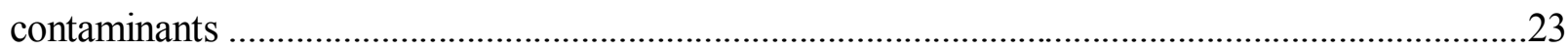

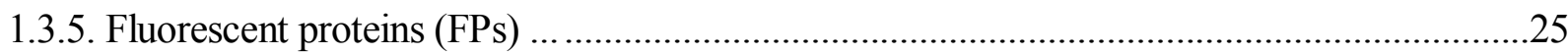

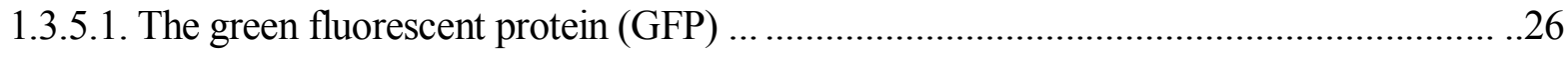

1.3.5.2. The red fluorescent protein (DsRed) .............................................................. 27

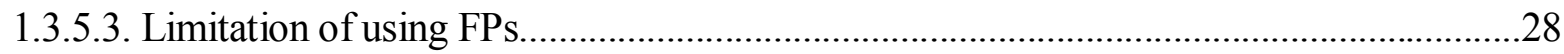


1.3.6. The 2,4-dichlorophenoxyacetic acid (2,4-D)- a widely used herbicide: .28

1.3.6.1. 2,4-D degradation ....... .29

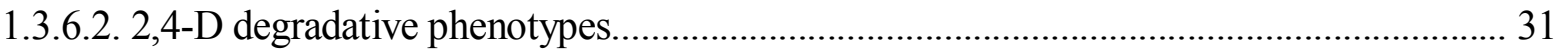

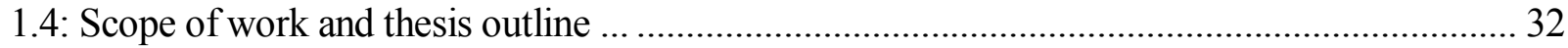

CHAPTER 2: PLASMID TRANSFER IN THE ABSENCE OF SELECTIVE PRESSURE .......33

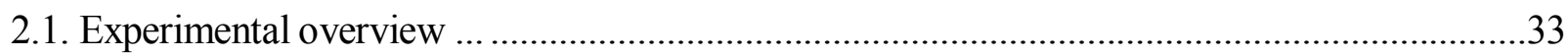

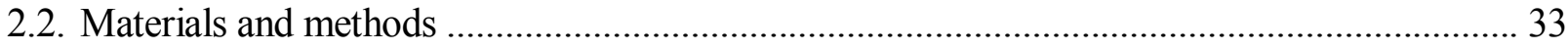

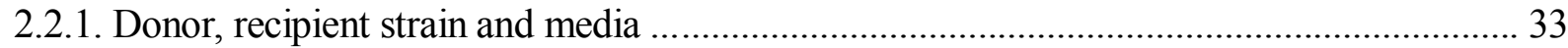

2.2.2. Plate mating experiment for plasmid transfer from donor to recipient cells

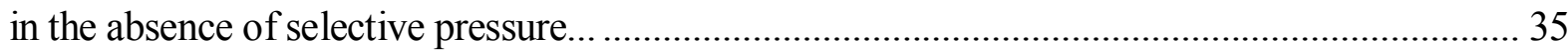

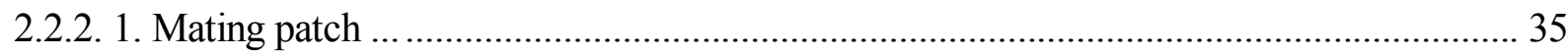

2.2.2.2. Microscopic detection of fluorescent cells in mating patch: .................................. 35

2.2.3. Flow cell preparation and inoculation for plasmid transfer from donor to defined biofilms

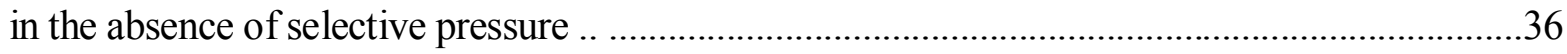

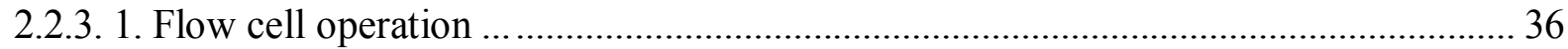

2.2.3.2. Microscopic detection of fluorescent cells in flow cell system ..................................38

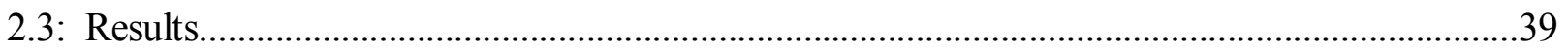

2. 3.1. Plate mating experiment (microscopic detection of transconjugant cells) .........................39

2.3.2. Flow cell experiments in the absence of selective pressure

(microscopic detection of transconjugant cells): .40 


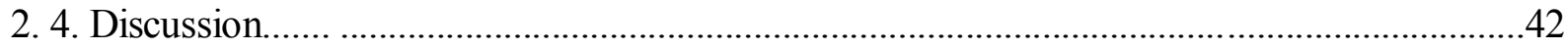

2.4.1. Presence of transconjugant cells in mating patch .......................................................42

2.4.2. Detection of transconjugant cells in continuous flow through system... ...................43

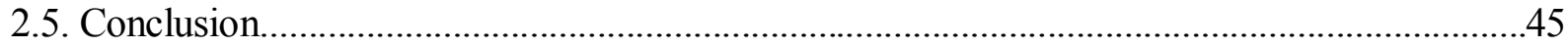

CHAPTER 3: CATABOLIC FUNCTIONALITY OF PLASMID pJP4 TRANSCONJUAGNT CELLS AND THEIR PLASMID STABILITY UNDER NON-

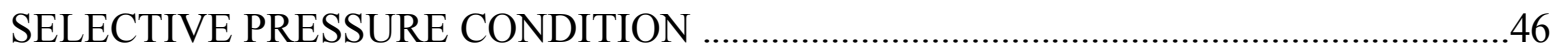

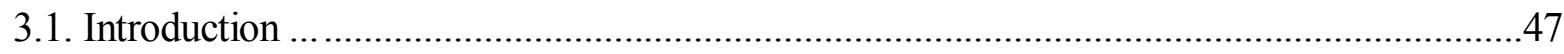

3.2. Methods and materials …………………………......................................................52

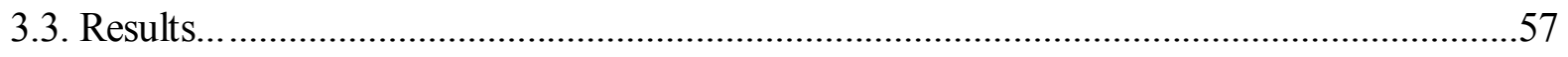

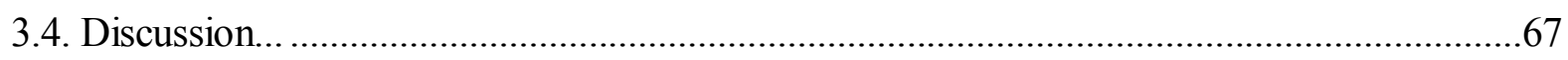

CHAPTER 4: CONCLUSIONS AND FUTURE RECOMMENDATIONS ...............................74

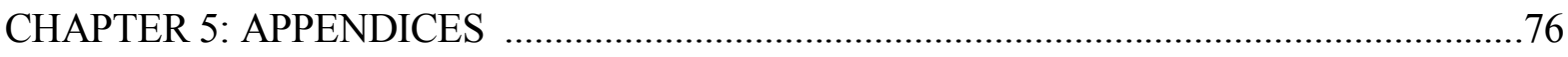

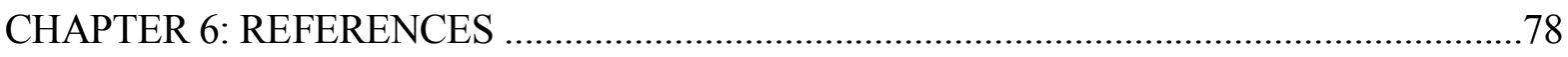




\section{List of Tables}

Table 1.1: Functions of open reading frames for $t f d$ genes in pJP4 related to 2,4-D degradation

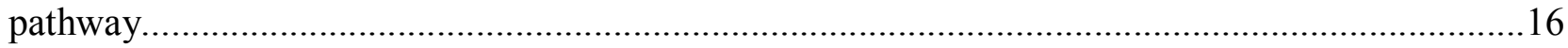

Table 1.2 : Plasmid pJP4 transfer in the presence of selective pressure $(2,4-\mathrm{D}) \ldots \ldots \ldots \ldots \ldots \ldots \ldots . . .20$

Table 1.3: Fluorescent detection of donor, recipient and transconjugant cells.................................27

Table 3.1: Enumeration of plasmid carrying transconjugant cells by microscopy and

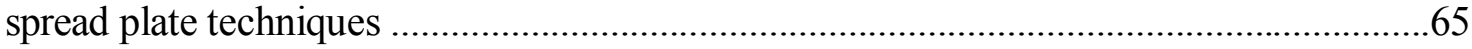




\section{List of Figures}

Figure 1.1: The interconnection between biofilms and HGT associated with plasmid transfer ......7 Figure 1.2: The degradative pathway of 2,4-D by Alcaligenes eutrophus with $t f d$ genes encoding

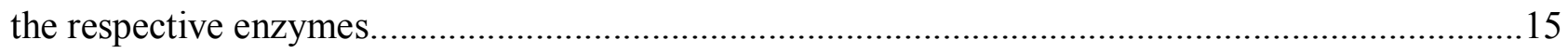

Figure 1.3: Genetic map of the 87,688 bp IncP-1 $\beta$ plasmid pJP4 ................................................17

Figure 1.4: Genetic organization of IncP-1 $\beta$ plasmid referred to pJP4 ..........................................18

Figure 2.1: Microscopic (CLSM) images of mating patch samples on day 14 .................................39

Figure 2.2: Microscopic (CLSM) images of flow cell experiment on day 8 ....................................40

Figure 3.1: 2,4-D concentration over time in batch cultures inoculated with plasmid pJP4 transconjugant strain in comparison to the plasmid donor strain, plasmid-free transconjugant strain, P. putida strain ATCC12633, E. coli strain, a soil -derived microbial community and an abiotic control. .59

Figure 3.2: OD measurement (at $600 \mathrm{~nm}$ ) of different cultures over time used in degradation reactors containing $\mathrm{MMN}+2,4-\mathrm{D}(1 \mathrm{mM})$

Figure 3.3: Growth curve of plasmid pJP4 transconjugant strain and generation time

determination

Figure 3.4: Microscopic (CLSM) detection of plasmid pJP4 in planktonic transconjugant cells over time .63

Figure 3.5: Detection of plasmid pJP4 by visual observation on $\mathrm{LB}+$ gentamicin and LB plates. . .66 


\section{List of Appendices}

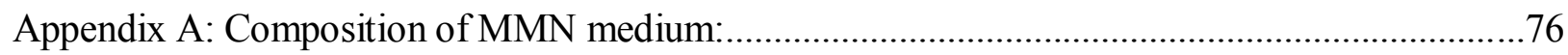

Appendix B: Calibration curve to spectrophotometrically monitor 2,4-D concentration............... 77 


\section{List of Abbreviations}

2,4-D : 2,4-Dichlorophenoxyacetic acid

ATCC :American type culture collection

BHR : Broad host range

bp : Base pair

CFU : Colony forming unit

CLSM : Confocal laser scanning microscopy

d : :Day

DSM : Deutsche sammlung von mikroorganismen (the German collection of microorganisms and cell cultures)

DsRed : Red fluorescent protein

dsRed : Gene encoding red fluorescent protein

EPS : Extracellular polymeric substance

F plasmid : Fertility plasmid

FPs : Fluorescent proteins

GC : : Gas chromatography

GFP : Green fluorescent protein

$g f p \quad$ : Gene encoding green fluorescent protein

Hfr $\quad$ :High frequency recombinants

HGT : Horizontal gene transfer

HPLC : High performance liquid chromatography

h $\quad$ : Hour

IncP-1 : Incompatibility group P1

IncP-2 : Incompatibility group P2 


\begin{tabular}{|c|c|}
\hline IncP-9 & : Incompatibility group P9 \\
\hline IS & : Insertion sequence \\
\hline $\mathrm{kb}$ & : Kilo base pairs \\
\hline lac repressor & :Lactose repressor \\
\hline LB & : Luria bertani \\
\hline MGEs & : Mobile genetic elements \\
\hline $\min$ & :Minute \\
\hline $\mathrm{MMN}$ & : Minimum mineral medium \\
\hline $\mathrm{mM}$ & : Millimole \\
\hline MWW & : Municipal wastewater \\
\hline NA & :Numerical aperture \\
\hline OD & : Optical density \\
\hline ORF & :Open reading frames \\
\hline oriT & :Origin of transfer \\
\hline PBS & : Phosphate buffered saline \\
\hline PCR & : Polymerase chain reaction \\
\hline rpm & :Revolutions per minute \\
\hline SBBR & : Sequencing batch biofilm reactor \\
\hline tra genes & :Transfer genes \\
\hline
\end{tabular}




\section{CHAPTER 1. INTRODUCTION}

\subsection{Project significance}

Environments such as ground water and soils have increasingly become contaminated by pollutants originating from industrial and agricultural sources. These pollutants are repeatedly released to the environments (Neilson et al., 1992). Many of the pollutants are very resistant to natural microbial degradation and cause mild to severe health problems. The widely used herbicide 2,4dichlorophenoxyacetic acid (2,4-D) has been considered as a significant environmental pollutant (Chong and Chang, 2009).

Chemical pollutants might persist in nature for the following reasons. First, microorganisms capable of biodegrading these toxic chemical compounds might not be found at the contaminated site. Second, microorganisms with functional catabolic genes, may be present, but some limiting factors (e.g. nutrient shortage) might create unfavorable conditions for the biodegradation of the contaminants.

Microorganisms living on a surface (inert or living) enclosed in a self produced extracellular polymeric substance (EPS) are known as biofilms (Madsen et al., 2012). Biofilms play an important role in degrading environmental contaminants. Many xenobiotics (man-made chemical pollutants) become adsorbed to biofilms (Bouwer, 1989, Wolfaardt et al., 1994). These xenobiotics exert selective pressure on biofilms and facilitate microbial adaptation to xenobiotics over time. Microbial adaptation might result from (i) an increase in the number of microorganisms with xenobiotics degradation capability, (ii) an increase in microorganisms which acquired mutations (such as, single nucleotide insertions, deletions, substitutions or DNA rearrangements) leading to a capability to degrade the xenobiotic in question or (iii) transfer of mobile genetic elements (MGEs) from a donor strain to the recipient biofilms through horizontal gene 
transfer (HGT) to increase the biodegradation potential (Liu et al., 1993, Top and Springael, 2003, Top et al., 2002). The introduction of new catabolic genes from donor strain to indigenous microbial population (through HGT) has an effective role, in situ to increase biodegradation potential in the contaminated environments (Top et al., 2002 , Filonov et al., 2010). It has been established that selective pressure is a very important factor in horizontal transfer of catabolic genes (Johnsen et al., 2007, Mohan et al., 2009). Plasmid transfer has been evaluated experimentally by comparing the number of transconjugants obtained with or without selective pressure (De Rore et al., 1994b). HGT (transfer of catabolic genes) seems to be higher in biofilm communities as compared to planktonic states (Madsen et al., 2012). Biofilms provide excellent conditions for plasmid transfer events because of (i) high cell density and (ii) well organized microbial community that allows physical cell to cell contact (Madsen et al., 2012). Conjugation is the mechanism of exchanging genetic information from one cell (donor cell) to another cell (recipient cell) mediated by direct cell to cell contact (Frost et al., 2010).

The transfer of catabolic plasmids by conjugation has been detected in many environments including soils, activated sludge, sediments and engineered and natural biofilms (Hausner et al., 2011). Degradation of 2,4-D mediated by genes on a plasmid was first described by Pemberton and Fisher(1977). The catabolic plasmid pJP4 carries genes ( $t f d A-F)$ for the degradation of 2,4-D (Don and Pemberton,1981, 1985). Plasmid pJP4 is a broad host range conjugative plasmid. It belongs to the incompatibility group P1 (IncP-1)and can be transferred between bacterial cells at high rates (Bathe et al,. 2004a). Postelnik (2012) observed plasmid pJP4 transfer events in a soil microbial community in the absence and presence of selective pressure. Shamsad (2012) could not detect plasmid pJP4 transfer microscopically in old biofilms (grown in a flow cell system) both in the absence and presence of selective pressure. 
Biofilm formation in single-species is considered to be a highly complex phenomenon related to nutritional status and other environmental conditions. This complexity seems to reasonably higher in the multi-species biofilms formation and their function will involve additional mechanisms and degree of complexity as compared to single species biofilms (Reisner et al., 2006). Cruz-Perera et al. (2013) observed that the ability of indigenous bacteria to receive conjugative plasmids is sometimes different in a mixed community (less physical cell-cell interaction opportunity between donor and specific recipient) as compared to single strain (high cell-cell contact between donor and recipient). To reduce the complexity in the microscopic study of plasmid transfer, the plasmid pJP4 transfer experiment was performed using a single strain of Pseudomonas putida as the recipient. This approach simplifies the experimental system and provides information about the plasmid transfer capability of the donor strain used as well as the effect of the experimental conditions to facilitate plasmid transfer. Effects observed in donor-recipient biofilms for plasmid transfer may provide the basis for relevant hypotheses applicable to more complex multi-species biofilms structure. Furthermore, there are few studies on plasmid pJP4 transfer in the absence of selective pressure in a defined (single recipient) biofilm. This study might generate some basic information to be considered for plasmid pJP4 transfer in non-selective pressure environments. On the other hand, to date there are very few data available on 2,4-D degradation studies of isolated plasmid pJP4 transconjugants. Bathe et al. (2004a) observed that despite possessing plasmid pJP4 (PCR confirmed the presence of plasmid in all tranconjugants), not all isolated transconjugant strains exhibited functional 2,4-D degradation phenotypes. 


\subsection{Objectives and hypotheses}

The objectives that need to be accomplished are (i) to determine the transfer of plasmid pJP4 in a model donor and single recipient biofilm in absence of selective pressure (ii) to study 2,4-D degradation capability of a plasmid pJP4 transconjugant (isolated from a soil microbial community) in a batch culture system and (iii) to evaluate the stability of plasmid pJP4 in planktonic cultures of transconjugant cells under non-selective pressure condition.

It was hypothesized that (i) the donor strain $P$. putida SM1443::gfp2x carrying the plasmid pJP4::dsRed could transfer the plasmid to recipient cells in the absence of selective pressure. The degree of complexity forming biofilms could be avoided to a greater extent as P. putida ATCC12633 would be used to form a defined biofilm. Plasmid transfer could be detected (presence of transconjugant cells) microscopically (confocal laser scanning microscopy) (ii) It was further hypothesized that plasmid pJP4 transconjugant cells possess 2,4-D degradation capability. Genes encoding 2,4-D degradation are located on this plasmid to confer degradation activity (iii) Further, transconjugant cells grown in planktonic cultures would not be able to maintain plasmid in absence of selective pressure, since pJP4 is relatively a large plasmid and may be lost from cells. The catabolic plasmid loss in planktonic cultures might be frequent due to uneven segregation. The lack of fitness cost (energy required for replication) may also cause rapid loss of plasmid from cells.

The overall objectives of the research work were focused to investigate the plasmid transfer in $P$. putida biofilms developed in continuous flow through system in the absence of selective pressure and to assess 2,4-D degradation capability of an isolated pJP4 plasmid transconjugant in a batch culture system along with the stability of the plasmid pJP4 in planktonic cultures under non selective pressure condition. The knowledge generated by the proposed research might be useful for future plasmid pJP4 mediated bioaugmentation studies of polluted environments. 


\subsection{Literature review}

\subsubsection{Biofilms}

Biofilms can be defined as complex aggregations of microorganisms that grow on a solid substrate (Qureshi et al., 2005). Biofilm is a gathering of bacterial cells living on a surface (inert or living) enclosed in a self produced extracellular polymeric substances (EPS) and environmental biofilms are typically multispecies communities (Madsen et al., 2012). Biofilm formation involves four steps (Stoodley et al., 2002) such as, (i) initial attachment (ii) irreversible attachment by the production of extracellular polymeric substances (EPS) from microbes (iii) early development and (iv) maturation of biofilm. It can be said that a biofilm starts with attachment of a free floating cell to a surface in contact with liquids (Qureshi et al., 2005). After the initial attachment step, the cell starts to form an association (temporary) with the surface (Watnick and Kolter, 2000). Then, it can attach irreversibly by producing EPS (Donlan and Costerton, 2002, Qureshi et al., 2005). Encased within EPS, biofilms grow and incorporate water channels to facilitate transport of nutrients. EPS are mainly composed of polysaccharides, proteins and nucleic acids (Madsen et al., 2012). EPS give biofilms stability and protection from environmental stresses such as antimicrobial agents, UV light

and dehydration (Stoodley et al., 2004). Wolfaardt et al.(1994) observed that microbial EPS play an important role in the bioaccumulation of contaminants in natural biofilms. Biofilms exert both positive and negative effects to the natural and man-made environments. In more than $65 \%$ of the hospital acquired microbial infections, biofilms have played critical roles (Ramage et al., 2006). Biofilms can also mediate biodegradation of chemical pollutants in the polluted environment. 


\subsubsection{Biofilm-mediated bioremediation}

Bioremediation is a technology to transform chemical pollutants present in the environment to less toxic intermediates or end products using microorganisms. Biofilm-mediated bioremediation is treated as an attractive solution to make the environment contaminants free due to the diverse structural and metabolic characteristics of biofilms (Edwards and Kjellerup, 2013). After development and subsequent maturation, biofilm develops water channels (Qureshi et al., 2005). The water channels throughout biofilms provide an effective way of exchanging nutrients and metabolites. They result in enhanced nutrient availability as well as removal of toxic metabolites from the contaminated environment sites (Sturman et al., 1995). Biofilms are generally applied to remediate high concentrations of chemical pollutants as such concentrations might be injurious to planktonic microorganisms (Edwards and Kjellerup,2013). In many cases, lack of either microorganisms the potential to degrade the contaminants or the required nutrients in biofilms may limit the success of biofilm-mediated bioremediation.

Bioremediation can be accelerated by the introduction of catabolic genes into a microbial biofilm community residing within a polluted environment. Catabolic genes can be introduced from donor strains to indigenous microorganisms in the polluted sites via HGT.

\subsubsection{Biofilm and horizontal gene transfer (HGT)}

For several decades, both HGT and biofilms have been considered as central areas of research of environmental microbiology with respect to bacterial adaptation and evolution. Biofilm seems to be the hot spot of HGT because in biofilms there is a dense microbial population and close contact 
exists among microorganisms (Madsen et al., 2012). Genetic bioaugmentation in biofilm systems has been studied in the past (Bathe et al., 2004a, Bathe et al., 2004b, Bathe et al., 2005). Exchange of genetic information within biofilms by plasmid transfer has been established by many studies (e.g. Hausner and Wuertz, 1999, Molin and Tolker-Nielsen, 2003).

Higher gene transfer in biofilms is generally observed (Madsen et al., 2012) and due to higher transfer frequencies plasmids may only be able to persist in biofilms (Lili et al., 2007). Krol et al. (2013) observed that plasmids that transferred well in a planktonic environment had also capability to show the highest transferability in biofilms (with few exceptions).

It has been established that there exists an interconnectedness (Fig. 1.1) between biofilm formation and horizontal transfer of mobile genetic elements (e.g. plasmids) (Madsen et al., 2012). Direct cell to cell contact between donor and recipient promotes interactions to transfer plasmid from donor to recipient and in time, may support enhanced biofilm formation (Ghigo, 2001).

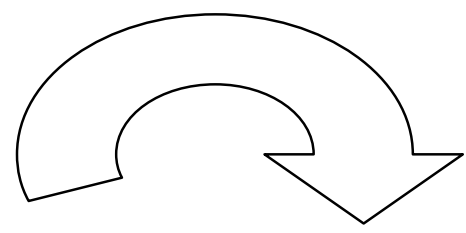

\section{Biofilm accelerates HGT}

Plasmid promotes biofilm formation

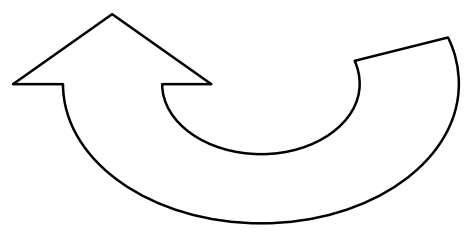

Fig. 1.1 : The interconnection between biofilms and HGT associated with plasmid transfer

HGT seems to play a crucial leading role to change the genetic characteristics of bacterial species (de la Cruz et al., 2000) including the acquisition of catabolic mobile genetic elements (MGEs). 


\subsubsection{Horizontal gene transfer (HGT)- an advantageous tool to acquire new catabolic pathways in bacterial populations}

Plasmid mediated HGT seems to be important for the adaptation of microbial communities to environmental stresses (Barkay et al., 1993, Lilley and Baily, 1997). In addition to conjugation, genes can be transferred among microbial cells via transformation and transduction.

\subsubsection{Mechanisms of HGT}

Bacterial conjugation, transduction and transformation/competence are the major mechanisms for HGT in the microbial world (Frost et al., 2010). During the 1930s and 1950s, these three mechanisms were discovered (van Elsas et al., 2002).

The majority of bacterial plasmids in the environment are transferred by conjugation (Davidson, 1999). Plasmid transfer may occur through sex pili (secreted on the donor cell surface) which interact with specific site on the surface of the recipient cell and this is commonly known as the physical nature of conjugation (Ghigo, 2001). HGT by conjugation mechanism facilitates an immediate change in the genetic characteristics of bacterial cells and thereby plays a leading role more quickly in the adaptation and evolution of bacteria as compared to mutation where genes are transferred only vertically to offspring.

Conjugative plasmids are transferred among both Gram-negative and Gram-positive microorganisms. One of the best studied conjugative plasmids that plays a role in Gram-negative bacteria such as $E$. coli is the F factor (F plasmid). Strains with an extrachromosomal F plasmid are called $\mathrm{F}^{+}$and act as donors. Strains without the $\mathrm{F}$ plasmid are $\mathrm{F}^{-}$and act as recipients. The conjugative functions of F plasmid are determined by transfer (tra) genes located on the tra operon. 
Transfer genes determine expression of F pili, synthesis and transfer of DNA and other functions. This conjugation is mediated by sex pilus and a type IV secretion system. Each $\mathrm{F}^{+}$cell binds to a specific outer membrane protein on the recipient bacteria with the help of pili and initiate mating. An intracellular cytoplasmic bridge is formed. Then one strand of DNA of F plasmid is transferred from donor to recipient (5' to $3^{\prime}$ direction). The transferred strand is then converted to circular double stranded F plasmid DNA in the recipient by complementary strand synthesis. This process is called rolling-circle replication. A new strand is also synthesized in the donor to replace the transferred strand. After successful plasmid transfer the $\mathrm{F}^{-}$recipient cell becomes $\mathrm{F}^{+}$(Willey et al., 2011, Firth et al., 1996). In this type of mating, chromosomal DNA is not transferred since the F plasmid is independent of chromosomal DNA. However, some cells can also integrate the F plasmid in their chromosome. These cells can function as a donor in conjugal matings. They can transfer chromosomal genes to recipients with great efficiency and are called Hfr (High frequency recombination) strains. This type of conjugation is called Hfr conjugation. Transfer of entire chromosome with the integrated $\mathrm{F}$ factor requires about 100 minutes in E. coli. In Hfr conjugation, the entire process is not generally completed as the connection between the cells usually breaks early. It causes the incomplete transfer of F Factor and ultimately the recipient remains $\mathrm{F}^{-}$(Willey et al., 2011). In $\mathrm{Hfr} \mathrm{X} \mathrm{F}^{-}$mating, most recombinants are not able to inherit the entire $\mathrm{F}$ plasmid and

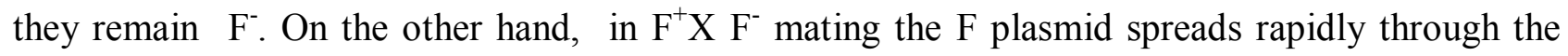
bacterial population and most recombinants are $\mathrm{F}^{+}$(Willey et al., 2011, Firth et al., 1996).

Conjugation also occurs in Gram-positive bacteria. Sex pili are not involved in gram-positive bacterial conjugation. For example, pheromone-responding conjugative plasmids are carried by enterococci. Recipient cells secrete peptide pheromones with specificities for donor cells with specific plasmids. Such donor cells proceed to produce adhesins. These adhesins allow the donor cells to aggregate with recipient cells, facilitating plasmid transfer (Grohmann et al., 2003). Most 
conjugative plasmids isolated to date in streptococci and enterococci are characterized as broad host range plasmids which transfer a broad spectrum of antibiotic resistance (Macrina et al., 1993).

Bacterial conjugation generally occurs in biofilms (dense communities expedite plasmid transfer) and biofilms are ideally suited to the exchange of genetic material of various origins (Hausner and Wuertz, 1999, Christensen et al., 1998). The conditions of the contaminated environment sites might influence plasmid transfer by affecting the survival of donors and recipients and the conjugation process itself (Trevors et al., 1986). The plasmid transfer events also depend on some plasmid specific characteristics and ecological factors that might affect host cells metabolism (Kues and Stahl, 1989, van Elsas and Bailey, 2002). In many cases, it was also observed that spatial and nutritional constraints might hinder the spread of plasmid transfer in established biofilms (Merkey et al., 2011). Christensen et al. (1998) observed that in complex biofilm environments, where cells are densely organized, newly formed transconjugant cells after plasmid transfer might be exposed to a number of environmental signals that could cause repression of pilus synthesis and then suppress further conjugation. In soil environment, nutrient and water availability might influence HGT by affecting density and metabolic activates of bacteria (van Elas and Bailey, 2002).

Transduction is the process where bacterial genes incorporated by bacteriophage particles can be transferred to another bacterium (Davidson, 1999). Transduction may be generalised (where any bacterial gene may be transferred) or specialized (where only genes located near the site of prophage integration are transferred). Large plasmids might not be possible to transfer by transduction mechanism (Stanisich and Bennette, 1976). An observation by Morrison et al. (1978) indicated that transduction might be an efficient way of genetic exchange in aquatic systems. Transformation mechanism is based on the uptake of free DNA from the environment and does 
not rely on mobile genetic elements (e.g. plasmids). It is solely encoded by the acceptor bacterium (Seitz and Blokesch, 2013). Many species of bacteria are naturally transformable (Davidson,1999). Lorenz and Wackernagel, (1994) listed 44 species of naturally transformable bacteria. Seitz and Blokesch, (2013) described that naturally transformable bacteria is highly biased towards genetic materials from the same or closely related species.

\subsubsection{Limitation of HGT}

Though horizontal gene transfer plays a primary role in the evolutionary shaping of bacterial community (Dorman, 2009) still there is a limited understanding of environmental factors ( e.g. temperature, moisture, nutrient availability) that affect rates of plasmid spread (Van Elsas et al., 2000). Another limitation of HGT is the inability to distinguish between plasmid transfer events and the subsequent growth of transconjugants (Rensing et al., 2002).

Xenobiotic catabolic genes located in mobile genetic elements (MGEs) can mediate HGT to initiate genetic bioaugmentation potential (Nojiri et al., 2004). HGT has been successfully demonstrated in the genetic bioaugmentation experiments and carried on at the lab scale to transfer MGEs from model donor to suitable recipient communities.

\subsubsection{Catabolic mobile genetic elements (MGEs)}

MGEs harboring catabolic genes play a pivotal role in the HGT of genetic information in the host cells and facilitate them to adapt to environmental stresses such as xenobiotics (Barkay et al., 1993, Tschape, 1994, Lilley and Bailey, 1997, Top et al., 2002, Johnsen et al., 2007). Transposons and plasmids are the examples of MGEs (Tsuda et al., 1999, Top et al., 2002). 
Bacterial transposons are discrete DNA, can be transferred from donor to recipient sites regardless of the genetic homology between donor and recipient and thereby expand the gene pool in a range of recipient bacteria (Stephenson and Warnes, 1996).

Plasmids are extra chromosomal and autonomously replicating elements (DNA molecule). Transfer (tra) genes contain information necessary for plasmid transfer and facilitate the formation of a mating pair between a donor and a recipient. Self-transmissible (also referred to as conjugative) plasmids carry their own tra genes. In contrast, mobilizable plasmids do not carry their own tra genes but can be "mobilized" because they utilize the products of mating pair formation genes coded on a different plasmid, often termed the helper plasmid. The oriT (origin of transfer) initiates the plasmid DNA transfer (Willetts and Wilkins, 1984). Mobilizable plasmids have the oriT (origin of transfer) sequence for initiation of DNA transfer which enables the DNA to replicate as it moves through the conjugative bridge (Grohmann et al., 2003). A third group of

plasmids, the non-mobilizable plasmids, are spread by transformation or transduction, but not by conjugation, because they are neither conjugative nor mobilizable (Smillie et al., 2010).

Plasmid bearing bacteria are frequently used in bioaugmentation strategies because catabolic genes for chemical pollutants degradation are mostly plasmid encoded (Newby et al., 2002).

\subsubsection{Catabolic plasmids}

Catabolic plasmids have been found in many soil bacteria with genes that have variable degradation capability for xenobiotics (Top et al., 2002). Degradation of xenobiotic by catabolic plasmids was first described almost 30 years ago and the number of functional plasmids in the list is increasingly continuously. During the last few decades, industrial and agricultural activities increased in the 
release of xenobiotics into the ecosystems. The catabolic functions of plasmids can be produced by either (i) spreading the genes in a microbial community, (ii) rearranging existing pathway genes, or (iii) fusing segments from a number of pre-existing catabolic genes into a new catabolic gene to form a new pathway (Top et al., 2002). Catabolic gene regulation resulting in the expression of xenobiotics-degrading phenotype of plasmid bearing transconjugant cells might depend on either (i) the genetic characteristics (e.g. guanine-cytosine content) of the transconjugants or (ii) the presence of additional carbon source (e.g. glucose) in the environmental conditions (Ikuma and Gunsch, 2012). Differences in the genomic guanine-cytosine content between the donor and the recipient may result in codon usage biases (Muto and Osawa, 1987) or lead to a lack of promoter recognition (Mulligan and McClure, 1986). The presence of additional carbon source may lead to the upregulation of genes present on catabolic plasmid (Ikuma and Gunsch, 2012).

Many catabolic plasmids are recovered from transconjugants and characterized (Top et al., 2002). Most of them are larger than $50 \mathrm{~kb}$ (Top et al., 2002). They are recorded in the literature for the degradation of different types of chemical compounds (especially those considered as environmental contaminants by engineers and scientists). Degradation of naturally occurring compounds are encoded by IncP-2 (incompatibility group P2) and IncP-9 (incompatibility group P9) plasmids whereas, man-made chemical compounds (xenobiotics) are degraded by broad host range (BHR) IncP-1 (incompatibility group P1) plasmids. IncP1 plasmids have broader host range than IncP-2 and IncP-9 plasmids (Top et al., 2000) and have been shown to be transferred between bacterial cells at high rates (Bathe et al. 2004a). It has been established by many studies (Wyndham et al., 1994, Beli et al., 1999) that catabolic plasmids play an important role to introduce new degradation pathways of contaminants by transferring catabolic genes from different microorganisms to suitable host cells. 
There are different types of catabolic plasmids with respect to their xenobiotics degradation capability (Top et al., 2002). Plasmid pJP4 is a catabolic plasmid that carries genes encoding enzymes needed for the degradation of a range of xenobiotics including 2,4-D.

\subsubsection{Plasmid pJP4 and its role in bioremediation}

A number of catabolic genes (encoded by plasmids) for the degradation of 2,4-D xenobiotic have been isolated and characterized (Don and Pemberton 1981, Top et al., 1995, Vedler et al., 2000) and plasmid pJP4 (size $88 \mathrm{~kb}$ ) is one of them. It is considered as one of the best characterized broad host range (BHR) catabolic plasmids (Don and Pemberton, 1985) and was first isolated by Don and Pemberton, (1981) from the strain Ralstonia eutropha (previously named Alcaligenes eutrophus) JMP134. Plasmid pJP4 carries genes needed for the degradation of 2,4-D and 3chlorobenzoate. Mercury resistance genes are also found on this plasmid (Trefault et al., 2004).

Plasmid pJP4 mediated bioaugmentation has been successful for the degradation of 2,4-D (Top et al., 1995). Many enzymatic steps are needed to degrade 2,4-D (Fig.1.2) and chromosomally encoded maleylacetate reductase is required for utilization of 2,4-D (Don and Pemberton 1981, Kinkle et al., 1993, Newby et al., 2000). 


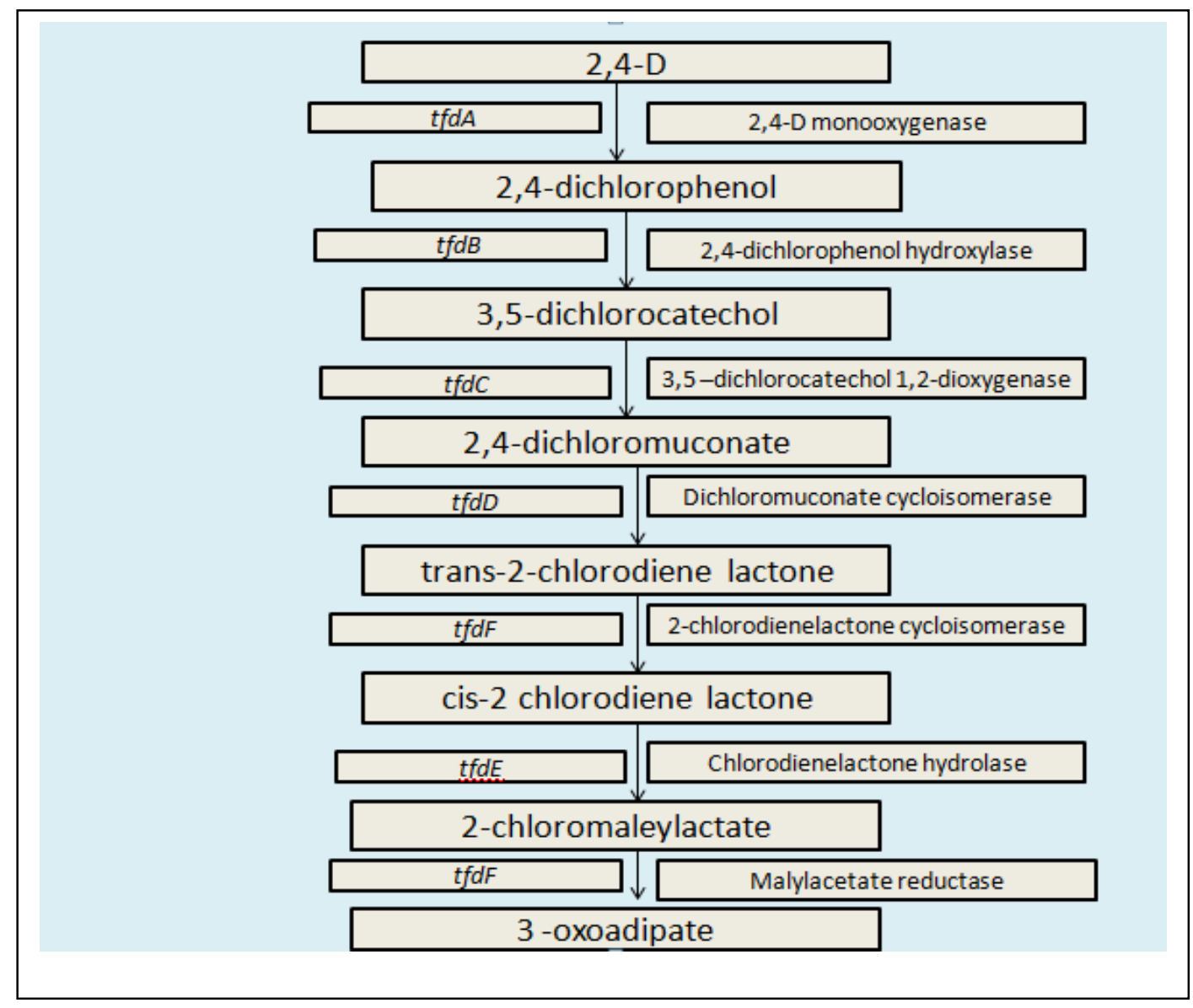

Fig. 1.2 The degradative pathway of 2,4-D by Alcaligenes eutrophus with $t f d$ genes encoding the respective enzymes (adapted from Fukumori and Hausinger, 1993)

Two degradative gene clusters $t f d$-I and $t f d$-II are required for 2,4-D and 3-chlorobenzoate degradation (Laemmli et al., 2000, Perez-Pantoja et al., 2003, Plumeier et al., 2002). Both the gene clusters are also required for the full protection of the toxic effect of intermediate products produced from xenobiotics and also ensure efficient growth in xenobiotics (Perez-Pantoja et al., 2003). The $t f d(A-F)$ genes located on plasmid pJP4 encode products needed for the conversion of 2,4- D to 2 chloromaleylacetate (Fukumori and Hausinger, 1993). In this plasmid, 15 open reading frames (ORF; putative protein coding genes) are $t f d$ genes and those encoding enzymes active in the 2,4-D degradation pathway are depicted in Table. 1.1(Trefault et al., 2004). 
Table. 1.1 Functions of open reading frames for $t f d$ genes in $\mathrm{pJP} 4$ related to 2,4-D degradation pathway (Trefault et al., 2004)

\begin{tabular}{|l|l|l|}
\hline ORF no. & $t f d$ genes & $\begin{array}{l}\text { Functions (encoding enzymatic } \\
\text { activities) }\end{array}$ \\
\hline 17 & $t f d B I$ & 2,4-dichlorophenol hydroxylase \\
\hline 18 & $t f d E I$ & Maleylacetate reductase \\
\hline 19 & $t f d E I$ & Dienelactone hydrolase \\
\hline 20 & $t f d D I$ & Chloromuconate cycloisomerase \\
\hline 21 & $t f d C I$ & Chlorocatechol-1,2-dioxygenase \\
\hline 25 & $t f d B I I$ & 2,4-dichlorophenol hydroxylase \\
\hline 26 & $t f d F I I$ & Maleylacetate reductase \\
\hline 27 & $t f d E I I$ & Dienelactone hydrolase \\
\hline 28 & $t f d C I I$ & Chlorocatechol-1,2-dioxygenase \\
\hline 29 & $t f d D I I$ & Muconate cycloisomerase \\
\hline 34 & $t f d A$ & 2,4-D/ $\alpha$-ketoglutarate dioxygenase \\
\hline
\end{tabular}

The distribution of the gene groups in the plasmid pJP4 is shown in Fig. 1.3. The overall guaninecytosine content of $\mathrm{pJP} 4$ is $64.7 \%$ which is similar to the genomic guanine-cytosine content of $R$. eutropha JMP 134 (64.4\%) (Trefault et al., 2004). 
Plasmid pJP4 contains mobile elements, including insertion sequences (IS) surrounding the tfd-II gene cluster (Leveau and van der Meer, 1997). In pJP4, the IncP-1 $\beta$ backbone is interrupted by Tn501 and the insertion sequence (IS) 1071 (Schluter et al., 2003) (Fig. 1.3).

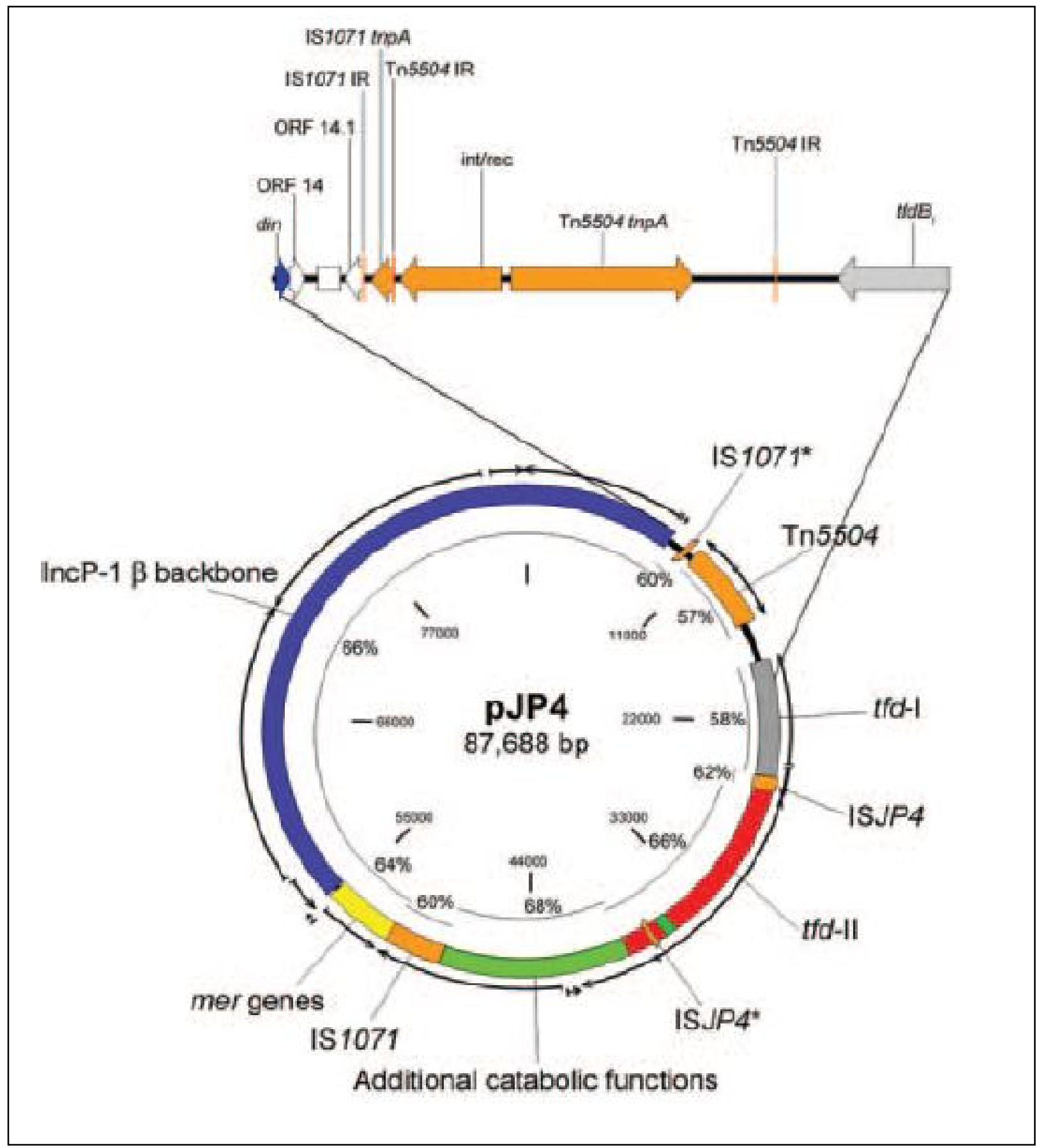

Fig. 1.3 Genetic map of the 87,688 bp IncP-1 $\beta$ plasmid pJP4. Coding region are shown by boxes (blue for IncP-1 $\beta$ backbone, grey for module $t f d-\mathrm{I}$, red for module $t f d-\mathrm{II}$, green for additional catabolic functions, yellow for mer genes and orange for mobile elements). Arrows and lines 
indicate the direction of transcription and guanine-cytosine content respectively. Insertion sequences IS $1071^{*}$ and ISJP4* represent truncated copies. The pJP4 region between the din (encoding the DNA-damage inducible protein) and $t f d B$ genes is shown in detail (reprinted with permission from Trefault et al., 2004).

The IncP-1 $\beta$ backbone in plasmid pJP4 (Fig. 1.4) is similar in genetic organization to the backbone of other IncP-1 $\beta$ plasmids. The backbone of a plasmid carries genes needed for the maintenance, replication or transmission of the plasmid (Burlage et al., 1990). Thus, the tra genes as well as the origin of replication are located on the backbone.

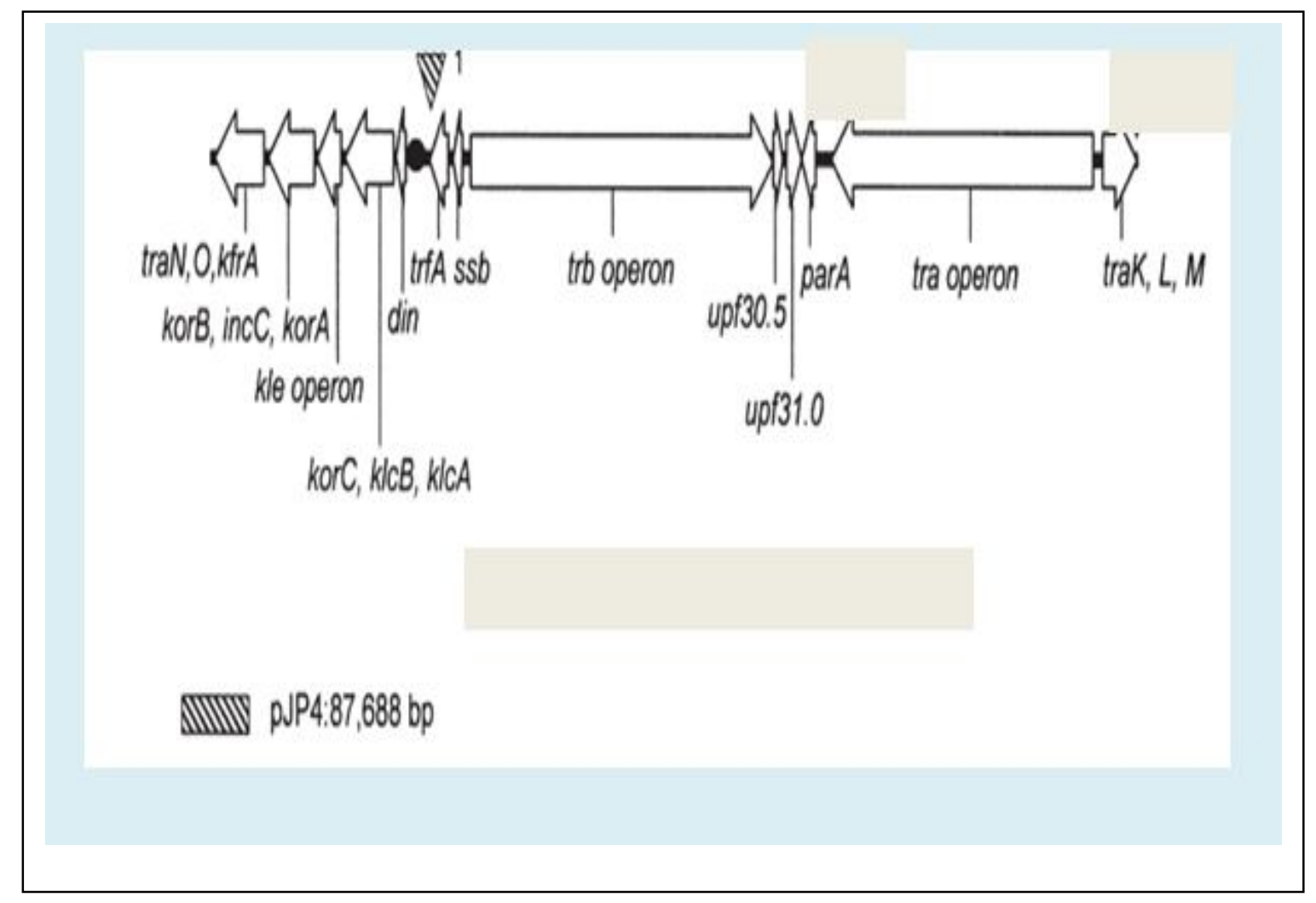

Fig. 1.4 Genetic organization of IncP-1 $\beta$ plasmid referred to pJP4. Relevant IncP-1 $\beta$ backbone genes are indicated. Arrow indicates transcriptional units in pJP4 (reprinted with permission from Trefault et al., 2004). 
The plasmid pJP4 was used as a model plasmid in many experimental model systems (Table.1.2) to test catabolic plasmid dissemination in contaminated soil, water and engineered environments (Newby et al., 2002, Quan et al., 2011 Aspray et al., 2005, Newby et al., 2000, Bathe et al., 2004b, 2005). 
Table. 1.2: Plasmid pJP4 transfer in presence of selective pressure $(2,4-\mathrm{D})$

\begin{tabular}{|c|c|c|c|c|c|}
\hline $\begin{array}{l}2,4-\mathrm{D} \\
\text { (concentration) }\end{array}$ & $\begin{array}{l}\text { Donor Strain with } \\
\text { plasmid pJP4 }\end{array}$ & $\begin{array}{l}\text { Reactor Type } \\
\text { and (recipient } \\
\text { community) }\end{array}$ & $\begin{array}{l}\text { Donor persistence/ } \\
\text { Transconjugant } \\
\text { emergence } \\
\text { (yes/No/ND*) }\end{array}$ & $\begin{array}{l}\text { Enhanced 2,4-D } \\
\text { degradation? } \\
\text { Yes/No }\end{array}$ & References \\
\hline $\begin{array}{l}2,4-\mathrm{D} \\
(100 \mathrm{mg} / \mathrm{L})\end{array}$ & P. putida SM11443 & $\begin{array}{l}\text { Microcosm and lab } \\
\text { scale } \\
(* * * \mathrm{MWW})\end{array}$ & ND/yes & Yes & Quan et al. (2011) \\
\hline $\begin{array}{l}2,4-\mathrm{D} \\
(1 \mathrm{~g} / \mathrm{L})\end{array}$ & $\begin{array}{l}\text { E. coli } \mathrm{HB} 101 \& \\
\text { P. putida KT2440 }\end{array}$ & $\begin{array}{l}\text { Activated sludge } \\
\text { reactor } \\
(\mathrm{MWW})\end{array}$ & ND/yes & Yes & Tsutsui et al. (2010) \\
\hline $\begin{array}{l}2,4-\mathrm{D} \\
(14 \mathrm{mg} / \mathrm{L})\end{array}$ & P. putida SM1443 & $\begin{array}{l}\text { Lab scale SBR } \\
\text { (wastewater) }\end{array}$ & Yes /yes & Yes & Quan et al. (2010) \\
\hline $\begin{array}{l}2,4-\mathrm{D} \\
(100 \mathrm{mg} / \mathrm{L})\end{array}$ & $\begin{array}{l}\text { Arthrobacter sp. } \\
\text { Bacillus subtilis, } \\
\text { Staphylococcus sp } \\
\text { and E. coli }\end{array}$ & $\begin{array}{l}\text { Acclimation reactor } \\
\text { (soil) }\end{array}$ & $\mathrm{No} / \mathrm{No}$ & Yes & $\begin{array}{l}\text { Chong and Chang } \\
(2009)\end{array}$ \\
\hline
\end{tabular}




\begin{tabular}{|c|c|c|c|c|c|}
\hline $\begin{array}{l}2,4-\mathrm{D} \\
\text { (concentration) }\end{array}$ & $\begin{array}{l}\text { Donor Strain with } \\
\text { plasmid pJP4 }\end{array}$ & $\begin{array}{l}\text { Reactor Type } \\
\text { and (recipient } \\
\text { community) }\end{array}$ & $\begin{array}{l}\text { Donor persistence/ } \\
\text { Transconjugant } \\
\text { emergence } \\
\text { (yes/No/ND*) }\end{array}$ & $\begin{array}{l}\text { Enhanced 2,4-D } \\
\text { degradation? } \\
\text { Yes/No }\end{array}$ & References \\
\hline $\begin{array}{l}2,4-\mathrm{D} \\
(25 \mathrm{mg} / \mathrm{L})\end{array}$ & P. putida SM11443 & $\begin{array}{l}\text { Flow chamber } \\
\text { system } \\
\text { (soil) }\end{array}$ & ND/yes & Yes & Aspray et al. (2005) \\
\hline $\begin{array}{l}2,4-\mathrm{D} \\
(2 \mathrm{mM})\end{array}$ & P. putida SM1443 & $\begin{array}{c}* * \text { SBBR } \\
\text { (wastewater) }\end{array}$ & Yes /yes & Yes & Bathe et al. (2004b) \\
\hline $\begin{array}{l}2,4-\mathrm{D} \\
\text { ( } 500 \text { and } 1000 \mu \mathrm{g} \\
/ \mathrm{kg} \text { soil) }\end{array}$ & E. coli ATCC 15224 & $\begin{array}{l}\text { Microcosm } \\
\text { (wastewater) }\end{array}$ & Yes /yes & Yes & Newby et al. (2000) \\
\hline $\begin{array}{l}2,4-\mathrm{D} \\
(500 \mu \mathrm{gm} / \mathrm{L})\end{array}$ & $\begin{array}{l}\text { A. eutrophus } \\
\text { JMP134 }\end{array}$ & $\begin{array}{l}\text { Microcosm } \\
\text { (soil) }\end{array}$ & ND/yes & Yes & Neilson et al. (1994) \\
\hline
\end{tabular}

$* \mathrm{ND}=$ not determined

$* *$ SBBR $=$ Sequencing batch biofilm reactor

*** MWW= Municipal wastewater 


\subsubsection{Catabolic plasmid stability in transconjugants}

For successful bioaugmentation, the stability of the catabolic plasmid of the recipient microbial community in the polluted site is highly important. Long term persistence of plasmids in their transconjugants might have the potential (i) to increase pollutant degradation capability for longer period for successful implementation of bioaugmentation strategy (ii) to function as a plasmid donor in the contaminated site for the spread of genetic materials in the indigenous microbial community. Environmental conditions influence to further transfer of plasmid from new plasmid donor cells (transconjugant cells) to recipient cells. Potential changes in environmental conditions (e.g. the presence of additional biodegradable carbon source, different $\mathrm{pH}$ values as well as different nitrogen sources) might alter plasmid transfer events and biodegradation potential (Ikuma and Gunsch, 2012, Braddock et al., 1997, Siddique et al., 2002).

In planktonic transconjugant cells, microbial activity is high and cells divide frequently. The rate of plasmid loss is potentially higher in planktonic state and plasmid free cells can rise over a short period of time. Transconjugant cells in biofilms are generally less active than their planktonic counterparts and lower bacterial activity leads to fewer cell divisions which ultimately can result in a high degree of plasmid stability (less plasmid loss) within biofilms (Madsen et al., 2012). It is established that biofilms (having well known spatial effect) not only facilitate significant plasmid transfer frequencies but also maintain greater plasmid stability (after successful plasmid transfer events) within their structured environment. Sharp et al. (1998) also observed the evidence of the higher stability of plasmids in biofilms. These observations were contradictory to other results described by Huang et al. (1993) who found that biofilms created higher plasmid loss in segregation as compared to planktonic cultures. Sharp et al. (1998) explained their results that net plasmid loss decreased in biofilms for higher plasmid transfer (due to high cell-cell contact) and slower growth 
rates of plasmid (due to less cellular division other than metabolic priority for EPS production). It might negate the higher plasmid loss resulting in an equivalent net plasmid loss. Greater plasmid (containing a particular antibiotic resistance gene) transfer frequency is also observed in presence of selection pressure (sub-lethal dose of that antibiotic) in biofilms (Ma and Bryers, 2012).

Another observation by Ikuma and Gunsch, (2012) is that the stability of the catabolic plasmid (TOL plasmid was used in this study) in transconjugants might be variable between strains. Plasmids loss from $90 \%$ of transconjugant cells were determined in Serratia marcescens TOL and E.coli TOL within 20 and 32 generations respectively. In $P$. putida TOL, loss of plasmid was observed within 80 generations and the TOL plasmid remained stable in $P$. fluorescens TOL for up to 65 generations. On the other hand, the loss of TOL plasmid occurred later for Pantoea agglomerates after 108 generations. This might suggest that the plasmid stability in host cells might depend on (i) the segregation frequency and/or (ii) the metabolic burden (energy required for replication) of catabolic plasmids. Their results also indicated that the stability of the TOL plasmid is strain specific with no correlation to the phylogenetic characteristics and genomic guanine-cytosine content. Transconjugant strains harboring a catabolic plasmid at the contaminated site, can play an effective role for genetic bioaugmentation of xenobiotics present in the environments over time. Genetic bioaugmentation is a method which may lead to the increase of catabolic plasmid-bearing cells at contaminated sites.

\subsubsection{Genetic bioaugmentation- a better strategy of cleaning up environmental contaminants}

Industrial production (mainly agrochemicals, petrochemical and pharmaceutical industries) of chemicals has resulted in contamination of many environments which causes ecotoxicological problems. These man-made chemical compounds present in the environment have created 
human health problems due to having their toxicity, mutagenic and carcinogenic properties (Mrozik and Piotrowska-Seget, 2009). Most of these chemical compounds are recalcitrant and can persist in the environment for years (Budavari, 1996). Major research topics of environmental engineers and scientists aim to develop better treatment methods for the degradation of persistent xenobiotics (Neilson, 1996, Singleton, 1994). There are many methods for the degradation of man-made chemical pollutants from the contaminated environments. Physicochemical approaches seem to be more effective than biological methods in this regard. But physicochemical methods are more expensive than biological ones. High energy and many chemical reagents are required to run physicochemical methods. For this reason, microorganisms capable of degrading or detoxification of toxic compounds known as bioremediation (Hausner et al., 2011) has become an effective approach and now is a widely used technology (Hamdi et al., 2007, Tsutsui et al., 2010). One of the in situ bioremediation strategies is bioaugmentation (Mrozik and Piotrowska-Seget 2009; Tsutsui et al., 2010). Bioaugmentation is a bioremediation strategy to introduce indigenous or genetically modified microorganisms to contaminant sites in order to remove fast the unwanted chemical pollutants (Tsutsui et al., 2010).

This conventional bioaugmentation efforts sometimes do not show effectiveness due to either (i) lack of degradation potential (decrease the number of population) or (ii) slow adaptation of the indigenous microorganisms to the contaminated environments (Top et al., 2002). Highly functional laboratory strains are required to carry on bioaugmentation study and can increase degradation potential of chemical compounds in soils (Dejonghe et al., 2001) and wastewater treating bioreactors (Van Limbergen et al., 1998). Bioaugmentation potential in these systems are often hindered due to rapid reduction of the number of introduced laboratory strains. (Newby et al., 2002). To survive in these unfavourable environmental systems is a not a easy task for these strains since they have to compete with indigenous microorganisms for resources and space (Top et al., 2002). 
To overcome the limitation discussed above, plasmid mediated bioaugmentation approach (genetic bioaugmenation) has been applied. HGT of catabolic plasmid carrying MGEs encoding relevant genetic information to indigenous microbial community can enhance bioaugmentation efforts, regardless of the survival of these introduced donor when genes are transferred and expressed in the indigenous microbial community (Top et al., 2002). Ikuma and Gunsch, (2012) discussed that transferred genetic information by HGT can ensure greater survival fitness in the contaminated sites in comparison to conventional bioaugmenation. The expression of transferred genetic materials labelled with fluorescent proteins (FPs) can be detected by microscopy application.

\subsubsection{Fluorescent proteins (FPs)}

The fluorescent protein (FPs) are frequently used as markers of catabolic genes to assess the extent of genetic bioaugmentation. It can describe a protein that has capability to become fluorescent spontaneously and for this property FPs have become attractive tools for a myriad for biological applications (Miyawaki et al., 2003). It is a technique to express the target protein fused to FPs (e.g. green fluorescent protein, red fluorescent protein) and thus helps to study the distribution of protein in its natural environment, the living cell (Stadler et al., 2013). FPs have become popular for cell biology applications as they have some unique properties such as (i) florescent signals that can be acquired very fast in real time (Jung et al., 2013) (ii) the advancement of current technology to improve the detection sensitivity and thereby facilitate the monitoring of a single fluorescent sample over a period of time (Peterson and Harris, 2010) (iii) FPs are available in multiple colours to enable multiplexed experiments (Gong et al., 2012) 
and (iv) FPs are stable in experimental environment and robust to biological reactions (Moreau et al., 2010). Fluorescent based methods permit the detection of donor and transconjugant strain in the environment samples. FPs (green fluorescent protein and red fluorescent protein) seem to be stable in both complicated and chemically defined medium (Ma and Bryers, 2012).

In many studies, the dual labelling of the donor strain is used to detect both donor and transconjugant cells in the samples used in experiments by microscopic visualization directly without using any additional staining method (Nancharaiah et al., 2003, Nancharaiah et al., 2008). In cancer cell biology, dual-color fluorescent cells (one color fluorescent protein in nucleus and another color fluorescent protein in cytoplasm) can be detected microscopically in living cells both in vivo and in vitro. In dual-color cells, red fluorescent protein (DsRed) is expressed in the cytoplasm of cancer cells, and GFP is expressed in the nucleus (Hoffman, 2014).

\subsubsection{The green fluorescent protein (GFP)}

The Nobel Prize in Chemistry was awarded in 2008 for the discovery and early use of green fluorescent protein (GFP) as a genetic reporter (Hoffman, 2014). The 30 different GFP like proteins containing, light-absorbing chromophores within their protein sequences have been extended till to date (Miyawaki et al., 2003). The $g f p$ gene encoding the GFP is a very useful tool as a reporter for studies of gene expression in single cells. The $g f p$ gene is also used as a reporter to study the kinetics of catabolic plasmids (e.g. TOL plasmid) transfer between bacteria grown on agar surfaces as well as to track individual cells in situ microbial community

(Christensen et al., 1998). Ma and Bryers (2012) used P. putida KT2442 strains expressing different variants of GFP. These FPs were used to determine conjugative transfer of plasmids harboring antibiotic resistant genes from model donor strains to biofilms. 


\subsubsection{The red fluorescent protein (DsRed)}

The red fluorescent protein is commercially available as DsRed (Matz el al., 1999). DsRed (a variant of GFP) matures slowly through a multi step process consisting of folding, chromophore formation and modification where as GFP requires folding and chromophore formation (Miyawaki et al., 2003). DsRed first expresses green fluorescence and then red over time as its chromophore structure is modified during maturation (Miyawaki et al., 2003). DsRed is widely used to detect transconjugants when all transconjugants carry $d s$ Red tagged plasmid and express red fluorescence (Bathe et al., 2004a, 2004b). Shamsad (2012) confirmed dsRed-tagged pJP4 plasmid transfer from donor to recipient in a mixed soil community.

In this study the donor strain used (chapter 2) is $P$. putida SM1443 (chromosomally labelled with a gfp gene and a dsRed labelled pJP4 plasmid). The donor strain shows GFP fluorescence (Table. 1.2) while its DsRed fluorescence is repressed due to the action of a chromosomally encoded LacI- repressor on the lac-promoter-controlled $d s R e d$ gene as described by Bathe et al. (2004b). DsRed is expressed in transconjugants after the transfer of pJP4 catabolic plasmid. $P$. putida ATCC 12633 used as recipient strain in this study (chapter 2) does not carry any FPs. The plasmid pJP4 transconjugant strain isolated by Shamsad (2012) used in this study (chapter 3) expresses red fluorescent. The plasmid pJP4 transconjugant strain is 97\% closely related to GenBank sequence of Pseudomonas oryzihabitans strain.

Table1.2: Fluorescent detection of donor, recipient and transconjugant cells

\begin{tabular}{|l|c|c|}
\hline & $\begin{array}{l}\text { green fluorescent } \\
\text { protein (GFP) }\end{array}$ & $\begin{array}{l}\text { red fluorescent } \\
\text { protein (DsRed) }\end{array}$ \\
\hline Donor & + & - \\
\hline Recipient & - & - \\
\hline Transconjugant & - & + \\
\hline
\end{tabular}




\subsubsection{Limitations of using FPs}

Though FPs are widely applied to determine gene expression and investigate the localizations of the sub-cellular distribution of proteins in living cells there still have several limitations (Jung et al., 2013). GFP itself is a large protein of 238 amino acids and some FPs tend to form dimers or tetramers (e.g. DsRed). The conjugation of GFP to a target protein has injurious effects on the functions and movements of the host protein cells (Lisenbee et al., 2003). The variants (e.g. DsRed) of GFP require a few hours of maturation time after expression to become fluorescently active (Chudakov et al., 2010; Miyawaki et al., 2003). Therefore, scientists have started to look forward for alternative approaches which can complement FP-based labeling methods.

\subsubsection{2,4-dichlorophenoxyacetic acid (2,4-D)-a widely used herbicide}

Many phenoxy compounds including 2,4-D have been applied as herbicides (mainly for weed control in agricultural crops such as wheat and maize) since 1946 (Werner et al., 2012). There are over 1,500 pesticide and herbicide products that contain 2,4-D as the main chemical ingredient (Howard, 1991). After more than 60 years of use, still 2,4-D is the third most widely used herbicide in USA and Canada (Industry Task Force II). The mechanism of action of 2,4-D is to stimulate (i) the effect of plant growth-regulating hormones, (ii) the growth of old cells and (iii) the overgrowth of young cells that leads to abnormal growth and causes death in some plants (Munro et al., 1992).

The sorption of 2,4-D to soils is significantly high (Werner et al., 2012), usually found in ground water (Howard, 1991) and has been considered as an environmental pollutant by engineers and scientists (Chong and Chang 2009). Once 2,4-D is released in groundwater, it can easily enter drinking water wells and cause mild to severe health problems. Depending on the living organisms, 2,4-D concentration (maximum contamination level in drinking water is $0.07 \mathrm{mg} / \mathrm{L}$ ) and the time to 
exposure, this compound can produce toxic effects ranging from embryo toxicity and teratogenicity to neuro-, immuno- and hepatotoxicy (Tuschl et al., 2003). If it is inhaled or taken at higher doses, it will damage kidney (Garabrant and Philbert, 2002).

The herbicide 2,4-D has been repeatedly detected in contaminated environments (Lipthay et al., 2001). The frequent occurrence of 2,4-D in the environment has become the reason for concern (Spliid and Koppen, 1998, Reitzel et al., 2004). It is therefore of interest to have a understanding of 2,4-D herbicide degradation.

\subsubsection{2,4-D degradation}

From the literature review, it has been observed that 2,4 -D degradation occurs either by (i) highly diverse microbial communities present in the contaminated environment (this natural degradation does not act efficiently as it occurs slowly, facilitates the accumulation of 2,4-D in the environment and thus constitutes a severe hazard), (ii) addition of exogenous microorganisms having 2,4-D degradation capability to the indigenous microorganisms in the polluted sites (this bioaugmentation process is very short acting which relies on the survival of introduced exogenous microorganisms), (iii) introducing genetically modified microorganisms to the contaminated environments (this genetic bioaugmentation process is considered as an effective tool for 2,4-D degradation. It is independent on the survival of introduced microorganisms because it also results in transfer of plasmid containing genetic materials from the introduced exogenous microorganisms to indigenous microorganisms).

HGT of catabolic genes allows genetically modified strains to use alternative carbon source by metabolizing 2,4-D xenobiotic (Top and Springael, 2003). Catabolic tfd genes for the degradation of 2,4-D to 2-chloromaleylacetate are located on the plasmid pJP4 (Perkins et al., 1990). 2,4-D degradation genes were expressed in Alcaligenes eutrophus, Variovorax paradoxus, and Pseudomonas putida but not in Escherichia coli, Rhodopseudomonas sphaeroides, Agrobacterium 
tumefaciens, Rhizobium sp., Pseudomonas fluorescens, or Acinetobacter calcoaceticus (Don and Pemberton, 1981).

Plasmid pJP4 has been successfully transferred to microorganisms within wastewater/ activated sludge communities and the emergence of transconjugants has enhanced 2,4-D degradation as described by Hausner et al. (2011). Plasmid pJP4 has become a model for the 2,4-D degradation (Dejonghe et al., 2000). Many plasmid mediation bioaugmentation (genetic bioaugmentation) studies have been focused on the herbicide 2,4-D (Bathe et al., 2004b, Aspray et al., 2005, Quan et al., 2011, Newby et al., 2002, Tsutsui et al., 2013). Tstusui et al. (2013) observed enhanced plasmid pJP4 mediated bioaugmentation using sequencing batch reactors for the removal of 2,4-D. Cupriavidus necator JMP134 and E. coli HB101 were used as plasmid donor strains. Complete removal of 2,4D was achieved in the reactor with $C$. necator JMP134. On the other hand, the reactor containing E. coli HB101 showed very low 2,4-D removal. They also isolated and characterized transconjugants. Some of the isolated transconjugants showed very fast degradation with respect to time as compared to donor strain.

In this research (chapter 3), 2,4-D as the target compound to degrade and plasmid pJP4 transconjugant were used to conduct a bioaugmenation study. This plasmid pJP4 transconjugant ( $97 \%$ closely related to GenBank sequence of $P$. oryzihabitans strain) was isolated by Shamsad (2012). The functionality of the plasmid pJP4 harboring 2,4-D catabolic genes is crucial to implement genetic bioaugmentation successfully in the contaminated environments. 


\subsubsection{2,4-D degradative phenotypes}

The functionality (in relation to degradation capability) of 2,4-D degradative phenotypes of the host cells is not solely related to successful plasmid transfer events. Transfer of catabolic plasmid to the recipient community as well as the parameters that ensure functionality of phenotypes after plasmid transfer are important for contaminant degradation (Ikuma and Gunsch, 2012). The functionality of catabolic phenotypes of the recipient cells is not solely related to successful plasmid transfer events.

In a previous study (Bathe et al., 2004a) it was observed that despite possessing degradative plasmid pJP4, only 7\% transconjugant strains carried functional phenotypes to degrade $2,4-$ D. Possible reasons for developing non-functional phenotypes due to the low expression levels of genes carried by the transferred catabolic plasmid in host cells because of (i) differences in genetic characteristics and cellular machinery between donor and host cells (Ikuma and Gunsch, 2012) (ii) the lack of capability of the host cells to transcribe the newly transferred catabolic genes and the toxicity of gene products and their concentration in the host cells (Newby et al, 2000; Kurland et al., 2003) or (iii) post transcriptional limitation of gene expression after plasmid transfer (Ikuma and Gunsch, 2010).

Ikuma and Gunsch, (2012) showed that both genomic guanine-cytosine contents and phylogenetic characteristics of transconjugants were important for the expression of TOL plasmid encoded phenotypes. They described that application of genetic bioaugmentation depends on the occurrence of transconjugants harboring functional plasmids to degrade contaminants rather than donor colonization. They also mentioned that the functional degradation of catabolic plasmids in transconjugants has been ignored in many studies. One of our research objectives was to perform a 2,4-D bioaugmentation study by an isolated transconjugant carrying catabolic plasmid pJP4. 


\subsection{Scope of work and thesis outline}

Still there are no studies on the plasmid pJP4 transfer under non-selective pressure condition in single strain recipient. On the other hand, there are very few data available on 2,4-D degradation activity of isolated plasmid pJP4 transconjugant cells and their capability to maintain plasmid in planktonic state under non-selective pressure condition. The scope of work was designed to address these gaps (i) by the detection of plasmid pJP4 transfer in a model donor-recipient biofilm in absence of selective pressure and (ii) by the characterization of the degradation functionality of an isolated plasmid pJP4 transconjugant under non-selective pressure condition. Research carried out within the frame of this thesis to satisfy the objectives is described in the following chapters. Chapter 2 reports the experiment results carried out to address the detection of plasmid pJP4 transfer in a model donor-recipient biofilm in absence of selective pressure. Chapter 3 is a formal manuscript that describes the studies on 2,4-D degradation and plasmid pJP4 stability in transconjugant cells. Chapter 4 outlines the conclusions and suggests future work as a follow up of this work. 


\section{CHAPTER 2: PLASMID TRANSFER IN THE ABSENCE OF SELECTIVE PRESSURE}

\subsection{Experimental overview}

The purpose of the plasmid transfer experiment was to check the functionality of the plasmid donor and fluorescent protein based system. The plasmid transfer experiment was divided into (i) a plate mating experiment (carried to detect transconjugant cells that expressed DsRed fluorescence using microscopy) and (ii) a flow cell system (used to develop biofilms from a recipient culture and transfer plasmid pJP4 from a donor strain under continuous flow conditions in the absence selective pressure).

\subsection{Materials and methods}

\subsubsection{Donor and recipient strains and media}

The strains used for this study were (i) the donor strain P. putida SM1443::gfp 2x carrying the plasmid pJP4::dsRed (Christensen et al., 1998; Bathe et al., 2004a, Bathe et al.,2004b) and (ii) $P$. putida ATCC 12633 used as a recipient strain.

The donor strain was chromosomally labeled with two copies of the $g f p$ gene and showed constitutive GFP fluorescence. $d s R e d$ was used in combination with $g f p$ for the differentiation between plasmid donor and recipient cells. DsRed fluorescence was repressed due to the action of a chromosomally encoded LacI- repressor on the lac-promoter-controlled $d s R e d$ gene as described by Bathe et al.(2004b). The DsRed was repressed in the donor cell but was expressed in host transconjugant cells after plasmid transfer. Upon transfer of catabolic plasmid pJP4 to recipient cells, the transconjugant cells were detected through visualization of their red fluorescence. The donor strain also carried chromosomal resistance against kanamycin and plasmidencoded resistance against gentamicin. Plasmid pJP4 encodes $t f d$ genes for $2,4-\mathrm{D}$ degradation. 
The recipient strain used in this study $P$. putida ATCC 12633 is also designated as $P$. putida DSM 291 (Ballerstedt et al., 2007). It is a strain with the GenBank sequence access no. of Z76667 (16S rRNA). This strain is known to have arsenate reductase genes $\operatorname{ars} C$ and $\operatorname{arr} A$ (Freikowski et al., 2010). This strain also possesses the following genes involved in catabolism of aromatic compounds such as (i) protocatechuate ( $p c a B C D F G H I J K R T)$, (ii) catechol branches $\beta$-ketoadipate pathway (catABR), (iii) homogentisate pathway ( $h m g A, m a i)$, (iv) central meta-cleavage ( $p c m),(\mathrm{v})$ p-hydroxybenzoate (pobAR) (vi) benzoate (benABCDE-1E-2FKR), (vii) phenyl acetate pathway (phaABCEFGIJKLJ1), (viii) n-phenyl alkanoic acids (fadABDHB1xD2Dx), (ix) phenylpropenoid compound (vanAB,ferR, ech, aat, acdA) and (x) phenylalanine/tyrosine (phhABR, tyrB-1B-2, hpd, $p c m$ ). This strain does not have the following genes (catC, fadAxB2x, fcs, pcaQ, phaDHMN, vdh, calB and catA2) (Ballerstedt et al., 2007).

The donor strain carrying the plasmid pJP4 was maintained on Luria Bertani (LB) agar (Becton Dickinson and company, Sparks, MD, USA) amended with kanamycin $(100 \mu \mathrm{g} / \mathrm{mL})$ and gentamicin $(25 \mu \mathrm{g} / \mathrm{mL})$. The recipient strain was routinely cultured on LB medium.

Minimum mineral medium (MMN) was prepared in this study as per description given by Boon et al. (2001). MMN containing various salts (Appendix: A) provided essential elements to allow bacterial growth. This MMN with 1mM (180 mg/L) glucose (Alfa Aesar, MA, USA) as sole carbon source was used for flow cell experiments. LB broth $(25 \mathrm{~g} / \mathrm{L}$, Becton Dickinson and company, Sparks, MD, USA) with kanamycin $(100 \mu \mathrm{g} / \mathrm{mL})$ and gentamicin $(25 \mu \mathrm{g} / \mathrm{mL})$ was used to grow donor strain for $48 \mathrm{~h}$ and only LB broth was used to grow recipient strain for $24 \mathrm{~h}$. Both donor and recipient strain were pre-grown on a $320 \mathrm{rpm}$ rotating shaker (for mixing and aeration) at room temperature. 


\subsubsection{Plate mating experiment for plasmid transfer from donor strain to recipient strain in the absence of selective pressure}

\subsubsection{Mating patch}

The pre-grown $1 \mathrm{~mL}$ cultures of both donor and recipient strain were centrifuged separately in 1.5 $\mathrm{mL}$ centrifuge tubes at $6000 \mathrm{~g}$ for $5 \mathrm{~min}$. Then supernatants were discarded and cell pellets were washed twice with $500 \mu \mathrm{L} 0.9 \%$ w/v of saline and vortexed for uniform mixing. Finally $500 \mu \mathrm{L}$ $0.9 \% \mathrm{w} / \mathrm{v}$ of saline was used to re-suspend the cell pellets. Afterwards, $400 \mu \mathrm{L}$ of each of the cultures (both donor and recipient) were mixed in a separate $1.5 \mathrm{~mL}$ centrifuge tube, vortexed and

immediately $100 \mu \mathrm{L}$ of this mixture was added to LB plate in one drop. $50 \mu \mathrm{L}$ of both donor and recipient culture were also added individually to the LB plates as controls. Plates were left at room temperature for $4 \mathrm{~d}$ and then wrapped with parafilm and stored at refrigerator (at $4^{\circ} \mathrm{C}$ ) for $14 \mathrm{~d}$. The two week incubation period was followed in order to allow for the slow maturation of DsRed and to ensure that red fluorescence developed in transconjugants to confirm the plasmid transfer from donor to recipient (Bathe and Hausner, 2010).

\subsubsection{Microscopic detection of fluorescent cells in mating patch}

Mating patch and control colonies were checked for GFP and DsRed fluorescence using Leica fluorescence dissection microscope (Leica Microsystems, Concord, ON, Canada). During the two week incubation period mating patches were sampled twice and examined by a confocal laser scanning microscope (Zeiss LSM510; Zeiss, Jena, Germany) to detect GFP and DsRed fluorescence (the presence of donor and transconjugant cells respectively) using $488 \mathrm{~nm}$ and $543 \mathrm{~nm}$ wavelength lasers respectively. 


\subsubsection{Flow cell preparation and inoculation for plasmid transfer from donor to a recipient biofilm in the absence of selective pressure}

A flow cell system in combination with microscopy was used to detect plasmid pJP4 transfer to recipient strain. Biofilms were developed in a stainless steel flow cell with four single channels (Wuertz et al., 2001) and plasmid transfer events were performed under continuous flow conditions using glucose as sole carbon source. Glass microscope cover slips, glued (with silicon glue) to the top and bottom of the flow cell served as the substratum for the biofilm growth and allowed direct microscopic observation (Venugopalan et al., 2005).

\subsubsection{Flow cell operation}

The stainless steel four channel continuous flow-through system (flow cell) consisted of four separate flow channels with individual dimensions of (length $\mathrm{x}$ width $\mathrm{x}$ height) $40 \mathrm{~mm} \times 4 \mathrm{~mm} \times 4$ mm. This flow cell was assembled with $0.17-\mathrm{mm}$-thick cover slides $(24 \mathrm{~mm} \times 50 \mathrm{~mm}$; VWR International, Mississauga, ON). These cover slips served as biofilm substratum. The flow cell inlets and outlets were connected to silicone tubing $(1.57 \mathrm{~mm}$ inner diameter; $3.18 \mathrm{~mm}$ outer diameter; $0.81 \mathrm{~mm}$ wall thickness; VWR International, Mississauga, ON). The flow cell with silicon tubes was autoclaved. Then the flow cell inlets and the influent reservoir were connected by silicon tubing. Flow cell channel outlets were also connected to bubble traps and effluent reservoir using silicone tubing. A multi channel peristaltic pump (Watson Marlow model 205S, Wilmington, MA) was used to deliver growth medium to the flow cells at a flow rate of $10 \mathrm{ml} / \mathrm{h}$. 
Though the entire set up was autoclaved prior to each experiment, the flow cell set-up, including tubing and bubble traps was additionally disinfected by rinsing with $10 \%(\mathrm{v} / \mathrm{v})$ bleach in distilled water approximately $1 \mathrm{~h}$ with a flow rate of $60 \mathrm{ml} / \mathrm{h}$. Then the flow cell was rinsed with distilled water (autoclaved) at the same flow rate $(60 \mathrm{ml} / \mathrm{h})$ overnight $(12-24 \mathrm{~h})$.

Next, MMN medium with $1 \mathrm{mM}$ glucose (sole carbon source) was pumped through the four flow cell channels for $1 \mathrm{~h}$ before inoculation with a flow rate of $60 \mathrm{ml} / \mathrm{h}$ to ensure the nutrient medium present inside the cell. Next, the medium flow was stopped, the silicon tubing was clamped, the surface of the tubing near the outlet of the flow cell was sterilized with $70 \%$ ethanol and then $1 \mathrm{ml}$ pre-grown $(24 \mathrm{~h})$ liquid culture of recipient strain was injected into three flow cell channels using a sterile $3 \mathrm{ml}$ syringe and a needle through the inflow side to fill each channel completely. The fourth channel was inoculated with only the donor strain (donor control). Inoculation was performed under sterile conditions, carefully avoiding formation of any air bubble inside the flow cell.

After inoculation the inflow side was detached with silicon tubing and the injection site was wiped for surface sterilization with a 70\% ethanol solution. Immediately the flow cell was turned upside down for $1-2 \mathrm{~h}$ so that the injected recipient culture would be able to attach to the glass cover slide. Then the MMN with $1 \mathrm{mM}$ glucose was pumped again with the flow rate of $10 \mathrm{ml} / \mathrm{h}$. All experiments were run at room temperature.

Biofilm development was checked by CLSM at different time intervals (12 h and $24 \mathrm{~h}$ ). After $24 \mathrm{~h}$ as per confirmation of biofilm development in the flow cell checked with CLSM, the pre-grown $(48 \mathrm{~h})$ donor strain was inoculated into each of the four channels of the flow cell. The fourth channel served as donor control. Prior to inoculation, donor cells harvested by 
centrifugation (5000 rpm, $8 \mathrm{~min}$ ) were washed twice by MMN and resuspended in MMN by vortexing. MMN with $1 \mathrm{mM}(180 \mathrm{mg} / \mathrm{L})$ glucose was pumped throughout the four channels with a flow rate of $10 \mathrm{ml} / \mathrm{h}$ (low level carbon source was used to ensure a slower growth of donor and recipient community as described by Ma and Bryers, 2012). Sterilization of injected site was done before and after inoculation as described before.

\subsubsection{Microscopic detection of plasmid transfer in flow cell system}

Then next step in the study was to detect plasmid transfer event in recipient strain using confocal laser scanning microscopy (CLSM). The experimental strategy for transconjugant detection (to confirm plasmid transfer in recipient strain) was (i) by developing of a biofilm in a flow cell system and (ii) by mounting the flow cell on the CLSM stage and performing a time series (4, 6 and $8 \mathrm{~d}$ ) of observations. To detect the presence of GFP and DsRed fluorescence in the recipient biofilm in the flow cell, $488 \mathrm{~nm}$ and $543 \mathrm{~nm}$ lasers were used respectively. A 63x/1.4 NA water immersion lens was used to generate all images. After day 4, donor and transconjugant cells were visualized directly in the biofilms using CLSM. Confocal laser scanning microscopy was performed using $488 \mathrm{~nm}$ and 543 laser settings for simultaneous monitoring of GFP and DsRed in single images as well as Z-stacks of overlay images. 


\subsection{Results}

\subsubsection{Plate mating experiment (microscopic detection of transconjugants)}

Pink colonies were observed on the mating patch after two weeks of incubation (data not shown). During the two week incubation period colonies developed on mating patch were checked for GFP and DsRed fluorescence by using Leica fluorescence dissection microscope (Leica Microsystems, Concord, ON, Canada). Microscopic slides were prepared with pink colonies collected from the mating patch on day 10 and day 14 and visualized under CLSM (Fig. 2.1). In the CLSM image of mating patch on day 14, plasmid pJP4 carrying transconjugant cells exhibited expected red fluorescence and donor strain exhibited green fluorescence. To detect GFP and DsRed fluorescence in the mating patch, $488 \mathrm{~nm}$ laser and a band pass filter of 500-550 $\mathrm{nm}$ and $543 \mathrm{~nm}$ laser and a long pass (LP) filter of $560 \mathrm{~nm}$ were used, respectively.

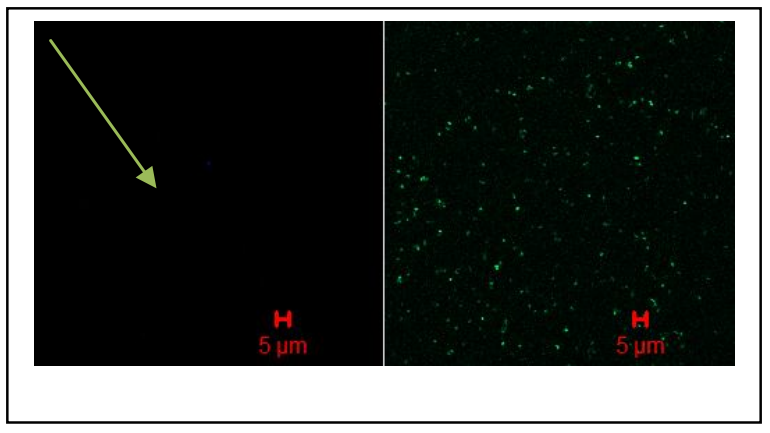

(a)

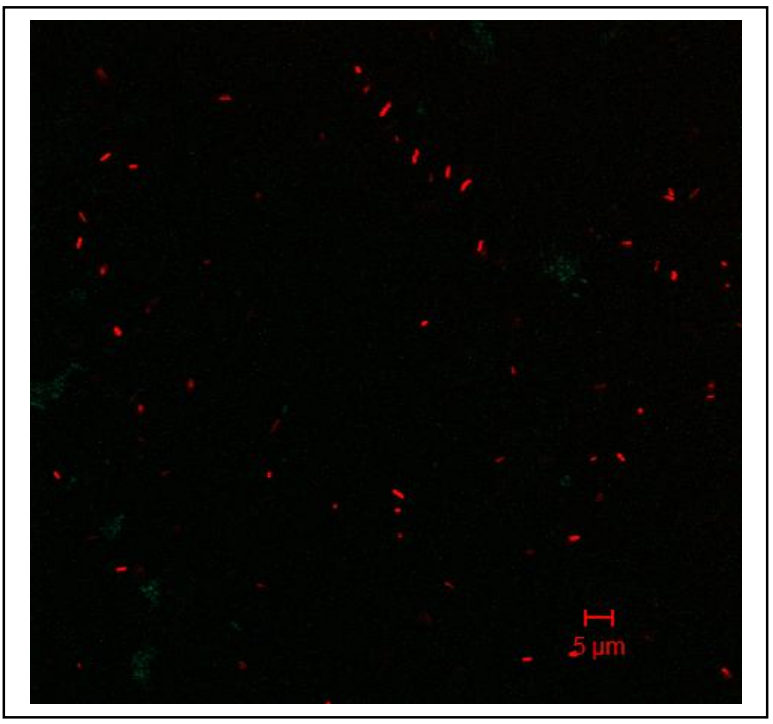

(b)

Fig. 2.1: Microscopic (CLSM) images of mating patch samples on day 14 (a) Image of donor control at $488 \mathrm{~nm}$ and $543 \mathrm{~nm}$ excitation wavelength. No red fluorescent cell was observed here (arrow). (b) Image of donor and recipient mating patch transconjugant at $488 \mathrm{~nm}$ and $543 \mathrm{~nm}$ excitation wavelength. Red cells indicated transconjugant cells and green cells represented donor cells. 


\subsubsection{Flow cell experiments in the absence of selective pressure}

\section{(microscopic based detection of transconjugant)}

Biofilm development at the glass surface of flow cell chambers was observed with CLSM. Channel 1,2 and 3 of the flow cell were inoculated with both the donor and the recipient strain, channel 4 received only the donor strain (donor control). Fig. 2.2 showed images of biofilm with added donor and recipient strain. Cluster of organisms forming the biofilm were seen
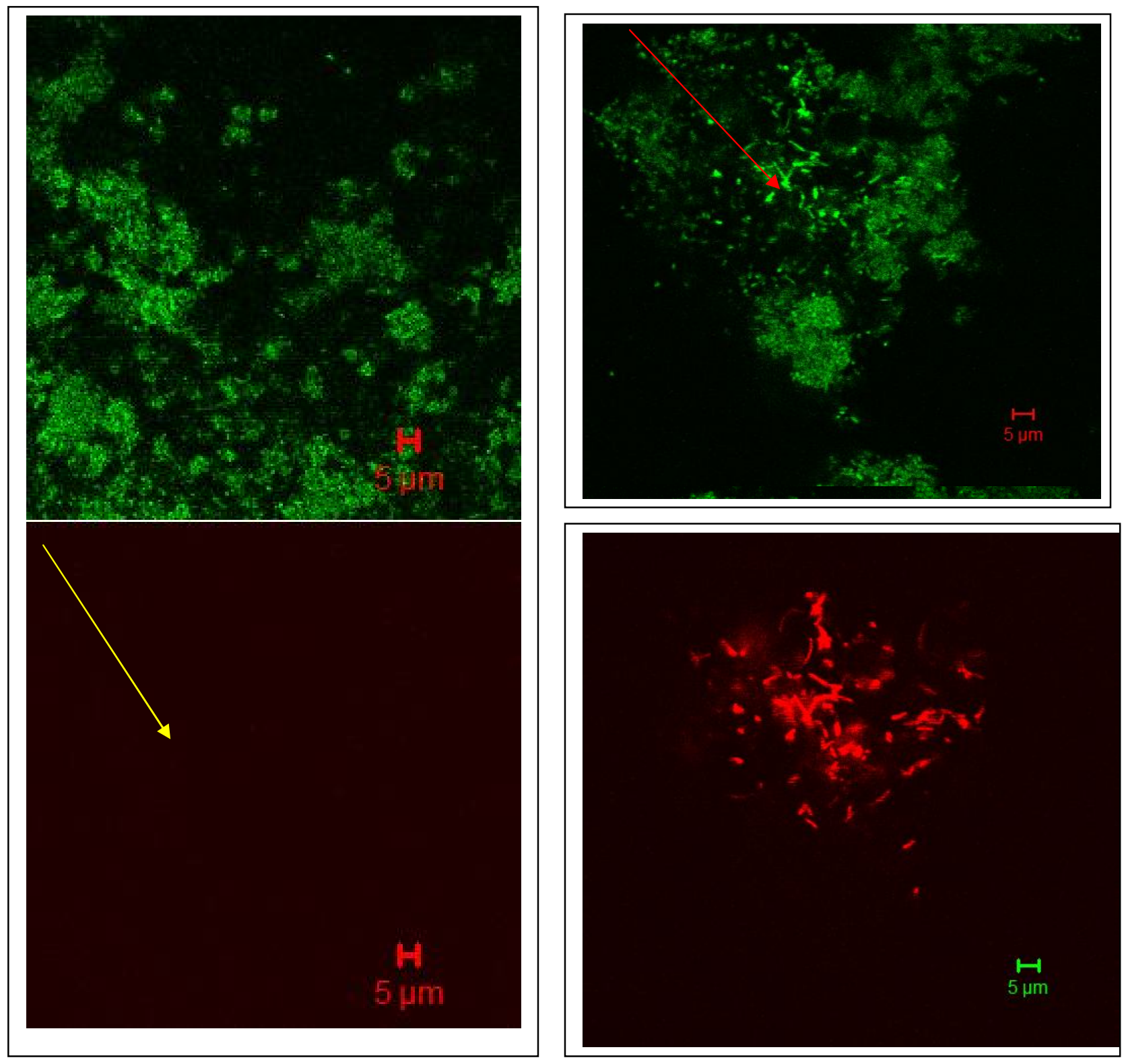

(a)

(b) and (c) 


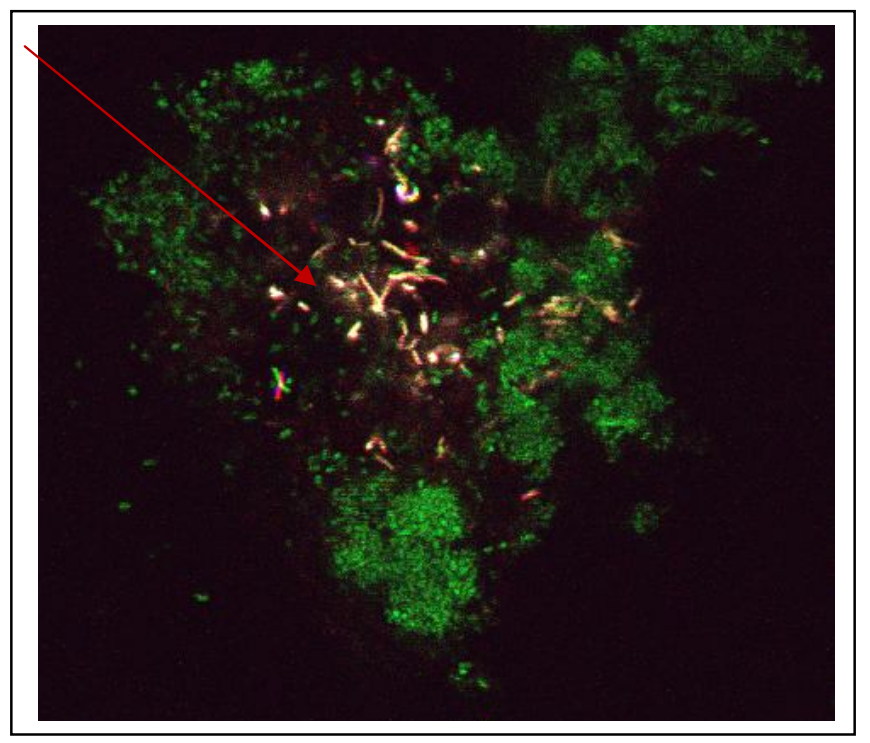

(d)

Fig. 2.2: Microscopic (CLSM) images of flow cell experiment on day 8 (a) Image of donor biofilm at $488 \mathrm{~nm}$ and $543 \mathrm{~nm}$ excitation wavelength. No red fluorescent cell was observed here (arrow). (b) Image of a biofilm with both donor and transconjugant cells, obtained at $488 \mathrm{~nm}$ excitation wavelength. Green cells represented donor cells forming biofilms, but also transconjugant cells possibly undergoing a transition from green to red during the maturation of DsRed (arrow). (c) Image of a biofilm showing transconjugant cells at $543 \mathrm{~nm}$ excitation wavelength (arrow). (d) Overlay image. Green cells represent donor cells while yellow cells represent transconjugant cells which at the time the image was obtained emitted both green and red fluorescence during the transition period of DsRed maturation. 


\subsection{Discussion}

The donor-single recipient strain defined biofilm system was a simplified approach and allowed the study of plasmid transfer events under defined conditions. The flow cell system is widely used as an ideal tool for the formation of single species/multispecies biofilms under varied experimental conditions (Venugopalan et al., 2005).

The plasmid transfer experiment was performed to ascertain that the plasmid could indeed be transferred to recipient cells. The mating experiment allowed close spatial arrangement of bacteria cells for the transfer of genes (through sex pili) and kept donor and recipient strain (i) in a close contact (ii) in a static condition and (iii) in a nutrient rich environment.

\subsubsection{Presence of transconjugant in mating patch}

Plate mating experiment between donor strain $P$. putida SM1443::gfp2x carrying the plasmid pJP4::dsRed and recipient strain $P$. putida ATCC 12633 was performed with an objective to evaluate the ability of the donor strain to transfer plasmid pJP4 to a single recipient strain $P$. putida ATCC 12633.

The pink colonies (cells expressing DsRed) were observed within the mating patch by visual inspection and using a dissection microscopy (data not shown). Transconjugant cells expressing DsRed fluorescence were also detected by CLSM (Fig.2.1b). In the donor control image (Fig. 2.1a) at $488 \mathrm{~nm}$ and $543 \mathrm{~nm}$ wavelength excitation, absence of red fluorescent cells (arrow) confirmed that $d s R e d$ gene was not expressed in the donor strain. After transfer of plasmid from donor to recipient, transconjugant expressed red fluorescence.

The observations mentioned above confirmed that the donor strain was able to transfer the plasmid pJP4 to the single recipient. As the donor strain was capable of transferring the plasmid to 
single recipient strain it can be concluded that the cellular machinery required for plasmid transfer event was functional in the model donor strain. In this initial plate mating experiments, it was confirmed that $P$. putida ATCC12633 was a suitable pJP4 recipient.

Many studies (Simonsen, 1990; Reisner et al., 2012; Neilson et al., 1994, Aspray et al., 2005) have conducted plasmid pJP4 transfer on agar plates. The donor strain P. putida SM1443 carrying the plasmid pJP4::dsRed mated with recipient cells (mixed microbial community) on nutrient rich solid agar media established plasmid transfer under optimal conditions (Bathe et al., 2004b, Aspray et al., 2005). The frequent transfer of plasmid pJP4 into single recipient culture on LB agar plates (Fig. 2.1) was observed microscopically because there might no physical separation between donor and single recipient cells and same bacterial genera (for donor and recipient strain) were used (Neilson et al., 1994; Frost, 1992). Simonsen (1990) described that most cells received the plasmid when plasmid transfer was monitored in agar surface cultures. Reisner et al., (2012) discussed that the spread of plasmid in agar colonies setup was generally limited independent of the type of conjugative transfer mechanism and sex-pilus characteristics. Then, the same donor and recipient strain was used for flow cell experiments with no selective pressure (in the absence of selective pressure).

\subsubsection{Detection of transconjugant in continuous flow through cell}

Images of the biofilms ( 8 day old) exposed to MMN + glucose were shown in Fig. 2.2. DsRed expressing transconjugants were detected in biofilms from the confocal images. Biofilms grown in flow chambers are more active in their outer layers as compared to their inner and subdued layers (Madsen et al., 2012). The reason might be due to the formation of substrates and nutrient gradients in the biofilms outer layers because of their spatial structure (Stewart and Franklin,2008). 
Christensen et al. (1998) reported that P. putida was the common species that could develop biofilms in the outer layers of flow chambers. An important advantage of using flow chambers in conjunction with fluorescent tags is that it allows direct observation of plasmid at the single cell level at young biofilm using CLSM (Aspray et al., 2005).

Fig. 2.2 (a) showed an image of biofilm with donor strain . MMN with $1 \mathrm{mM}$ glucose (as feed) and $488 \mathrm{~nm}$ and $543 \mathrm{~nm}$ wavelength laser were used. In this image, absence of red fluorescent cells (arrow) confirmed that DsRed fluorescence repression mechanism was properly functional in the donor strain. Fig. 2.2 (c) showed that DsRed expressing transconjugants were detected in the biofilms from confocal images at $543 \mathrm{~nm}$ wavelength excitation on day 8 . Transconjugant cells that carry $d s R e d$ tagged plasmid pJP4 and express red fluorescence. Fig. 2.2 (b) and 2.2 (d) showed that DsRed fluorescing transconjugants and green fluorescing donor cells might be present together in the biofilms ( 8 day old). Because DsRed, a GFP like protein matured slowly and both green and red emission (Fig 2.2 d) might have been detected during the transition state where DsRed fluoresced green (Fig 2.2 b) and red, due to structural modification during maturation (Miyawaki et al., 2003). Fig. 2.2 (b) and Fig 2.2(d) also showed that a high density zone of transconjugant cells was observed where donor cells in biofilm were present in high density and this result was similar to a previous study performed by Christensen et al. (1998).

In biofilms (more than 8 day old), DsRed fluorescing transconjugant cells could not be able to detect easily (data not shown). It might be due the formation of thick biofilms in the flow cell channels. Thick biofilms might hinder the donor cells to penetrate into the inner parts of biofilm (Ma and Bryers, 2012). Licht et al. (1999) observed that plasmid transfer in biofilms (where donor and recipient cells were in fixed spatial locations) occurred very fast initially, after that no 
further transfer was detected, even large recipient population still persisted. The fixed position of the recipient cells and their high density might form initial mating pairs, when donor cells attached. Minimum mineral medium (MMN) with a very low concentration of glucose ( $1 \mathrm{mM}$ equivalent to $160 \mathrm{mg} / \mathrm{L}$ ) as a sole carbon source was used in this plasmid transfer experiment. Low nutrient availability might develop heterogeneous and porous biofilms (and vice versa) and facilitate to detect transconjugant cells after plasmid transfer as described by Ma and Bryers, (2012).

\subsection{Conclusion}

The pJP4 plasmid was transferred to a single recipient strain in both plate mating and flow cell experiments. Transconjugants were detected in biofilm developed in the flow cell system. In the flow cell experiment glucose was used as carbon source, representing the absence of selective pressure. Detection of DsRed in the mating patch also initially confirmed the functionality of the plasmid transfer detection system. Using single strain as a recipient (other than mixed soil microbial community) simplified experimental design of plasmid pJP4 transfer events in biofilms. 


\title{
CHAPTER 3: Catabolic functionality of plasmid pJP4 transconjugant cells and their plasmid stability under non-selective pressure condition
}

\begin{abstract}
Plasmid mediated bioaugmentation (genetic bioaugmentation) utilizing horizontal gene transfer approach has been used to enhance bioremediation. The conjugative transfer of self transmissible catabolic plasmids from a donor strain to indigenous bacteria can increase biodegradation potential of an existing microbial community. In many cases, this conjugative transfer of catabolic genes to recipient cells might not result in a functional degradative phenotype of the plasmid in receipt cells. Despite possessing degradative plasmids, not all isolated transconjugant strains carrying catabolic plasmids exhibit degradative functional phenotypes. The main objective of this study was to investigate 2,4 dichlorophenoxyacetic acid (2,4-D) degradation capability of a catabolic plasmid pJP4 transconjugant strain isolated from a soil bacterial community in a batch culture system and the plasmid stability of this transconjugant under non selective pressure condition. The results showed that the reactor with plasmid pJP4 transconjugant strain contained less than $5 \%$ of the initial concentration $(221 \mathrm{mg} / \mathrm{L})$ of 2,4-D (concentration of 2,4-D was measured spectrophotometrically at 230 $\mathrm{nm}$ ) after $12 \mathrm{~d}$ whereas, the reactors with donor $P$. putida SM1443 carrying plasmid pJP4, $P$. putida ATCC12633, plasmid free transconjugant strain and a soil microbial community contained $30 \%, 60 \%, 80 \%$ and $37 \%$ of the initial concentration of $2,4-\mathrm{D}$ respectively. The capability of this transconjugant to maintain plasmid (plasmid loss rate) in a planktonic state was also tested under no selective pressure. Plasmid pJP4 was lost from almost 70\% of the population within 24 generations (the presence of the plasmid was detected by confocal laser scanning microscopy and spread plate techniques). These observations may be useful for future plasmid pJP4 related genetic bioaugmentation studies of polluted environments.
\end{abstract}




\section{Introduction}

Horizontal gene transfer (HGT) occurs naturally in contaminated environments and enhances bacterial adaptation to contaminants (Top et al., 2003). Genetic bioaugmentation also known as in situ bioremediation, seems to enhance the naturally occurring phenomenon to further increase the biodegradation potential of target contaminants. Plasmid mediated bioaugmentation (genetic bioaugmentation), has been successfully used for the horizontal transfer of self transmissible catabolic plasmids from donor strain to indigenous bacteria (Top et al., 2002). Catabolic plasmids encode genes for the degradation of target contaminants and thus enhance bioaugmentation potential at the polluted sites.

Indigenous microorganisms harboring catabolic genes transferred from donor strains seem to have greater survival fitness in the contaminated environments. In the contaminated environments (where genetic adaptation is required for the survival of microorganisms) genetic bioaugmentation may be effective to improve the biodegradation of target contaminants as compared to conventional bioaugmentation (which relies on the survival of exogenous microorganisms) (Ikuma and Gunsch, 2012).

As an outcome of this genetic bioaugmentation, catabolic phenotypes (observable characteristics) upon plasmid conjugation are expressed in recipient cells. The functionality (in relation to degradation capability of xenobiotics) of catabolic phenotypes of the recipient cells is not solely related to successful plasmid transfer events. Genetic and phylogenetic characteristics are important in controlling phenotype functionality of the plasmid. Ikuma and Gunsch, (2012) showed that both genomic guanine-cytosine contents and phylogenetics 
of transconjugants were important for the expression of TOL plasmid encoded phenotypes. The catabolic functions of transconjugants might be limited due to the low expression of genes on the transferred plasmid due to differences in genetic characteristics and machinery between the donor and recipient genomes.

In a previous study (Bathe et al., 2004a) using another catabolic plasmid, plasmid pJP4, it was observed that despite possessing plasmid pJP4 as confirmed with PCR and plasmid specific-primers, not all isolated transconjugant strains exhibited functional 2,4-D degradation phenotypes. Out of 56 isolated pJP4 transconjugant strains only 4 transconjugants (affiliated with $P$, putida and Delftia acidovorans) showed 2,4-D degradation capability. Probable reasons for developing non-functional phenotypes might be either (i) the lack of capability of the host cells to transcribe the newly transferred catabolic genes, the toxicity of gene products and their concentration in the host cells (Newby et al, 2000, Kurland et al., 2003) or (ii) post transcriptional limitation of gene expression after plasmid transfer (Ikuma and Gunsch, 2010).

For the effective genetic bioaugmentation (plasmid mediated bioaugmentation) as a long-term functional strategy, the stability of the catabolic plasmid over a long period in the recipient microbial community at the polluted site is highly important. Transconjugant strain harboring a catabolic plasmid at the contaminated site, can play an effective role for xenobiotic degradation as a continuous process over time (Ikuma and Gunsch, 2012).

Previously (Bathe et al., 2004b, Bathe et al., 2009) it was observed that enhanced xenobiotic degrading community was established in bioreactors by inoculating catabolic plasmid carrying donor strain and subsequent plasmid transfer to indigenous bacteria. To date, little quantitative data is available on catabolic functionality of isolated plasmid pJP4 transconjugants. However, for the 
successful survival, the laboratory introduced transconjugant strains has to perform a difficult task to compete with the resident bacterial community under natural conditions in making bioaugmentation a successful biotechnological technique (Bathe et al., 2004, Bathe et al., 2005, Nancharaiah et al., 2008).

For the successful genetic bioaugmentation, the stability of the catabolic plasmid of the recipient microbial community at the polluted site is highly important. In planktonic transconjugant cells, microbial activity is high and cell divides frequently. The rate of plasmid loss is potentially higher here and plasmid free cells can rise over short period of time. Transconjugant cells in biofilms are generally less active than their planktonic counterparts and lower bacterial activity leads to fewer cell divisions. Fewer cell divisions in biofilms might decrease the rate of plasmid loss due to the reduced metabolic burden (energy required for replication) for plasmid maintenance which ultimately can result in high degree of plasmid stability (less plasmid loss) within biofilms (Madsen et al., 2012). The mechanisms by which the fitness costs (metabolic burden) of plasmid maintenance operates are still unclear (Seoane et al., 2010). The fitness costs might be operated as per three group of hypotheses (Slater et al., 2008) such as, (i) the fitness costs might be an effect of plasmid encoded protein expression (Rozkov et al., 2004) (ii) they might relate to an effect to replicate and transfer plasmid DNA (Bjorkman and Andersson, 2000) and (iii) those which look for disorders in the cellular regulatory mechanisms (Ricci and Hernadez, 2000). Metabolic burden negatively influences the growth rate of plasmid carrying cells (as long as no plasmid specific selection is present) as compared to plasmid free cells (Corchero and Villaverde, 1998).

Plasmid free cells grow slightly faster (tied to the availability of substrates) and can establish them at the outer active layer of biofilms (Madsen et al., 2013). Unlike biofilms, the cells in planktonic system are not subject to specific active and inactive layers. Plasmid harboring cells and plasmid 
free cells grow in planktonic system as long as substrate is available and they become inactive when substrate have been depleted. This is definitely a major difference between growth in biofilms and in planktonic cultures (Madsen et al., 2013). The inactive planktonic cells will be more vulnerable when exposed to biotic and abiotic stresses compared to cells in biofilms (Cerca et al., 2006, Harrison et al., 2007, Matz et al., 2005, Pamp et al., 2008).

It is established that biofilms (having well known spatial effect) not only facilitate significant plasmid transfer frequencies but also maintain greater plasmid stability (after successful plasmid transfer events) within their structured environment. Greater plasmid (containing a particular antibiotic resistance gene) transfer frequency is also observed in presence of selection pressure (sub-lethal dose of that antibiotic) in biofilms (Ma and Bryers, 2012). Sharp et al. (1998) also observed the evidence of the higher stability of plasmids in biofilms. These observations were contradictory to other results described by Huang et al. (1993) who found that biofilms created higher plasmid loss in segregation as compared to planktonic cultures. Sharp et al. (1998) explained their results that net plasmid loss decreased in biofilms for higher plasmid transfer (due to high cell-cell contact) and slower growth rates of plasmid (due to less cellular division other than metabolic priority for EPS production). It might negate the higher plasmid loss resulting in an equivalent net plasmid loss. Ma et al. (2013) found that the number of plasmid free cells was higher in biofilms compared to their planktonic counterparts. They found an interesting observation that was an overall higher ratio of plasmid free cells present in biofilms than their planktonic counterparts. Due to the difference in spatial structure more plasmid free cells are present in biofilms than in planktonic cultures (Madsen et al., 2013). Madsen et al. (2013) also described that plasmid would eventually become completely lost from planktonic cultures (as there is no active or inactive layer like biofilms) over time. Plasmid carrying cells will be stored in the inactive (bottom) layers of biofilms over time. When biofilms become thick the bottom layers of 
biofilms will eventually become inactive (Pamp et al., 2008) and plasmid harboring cells present at the bottom of biofilm are less active and then less likely to lose the plasmids. For this plasmid carrying cells can be maintained in biofilm structures over a long period.

Ikuma and Gunsch, (2012) showed that the maintenance of plasmids in transconjugants might have an important impact on genetic bioaugmentation as well as have long term effect on the microbial community in the contaminated environments. Long term persistence of plasmids in their transconjugants might have the potential to increase pollutant degradation over a longer period and function as a plasmid donor (to transfer plasmid in the indigenous microorganisms) in the contaminated site for successful implementation of genetic bioaugmentation. Therefore, the stability of the plasmid pJP4 in transconjugant was tested as an another parameter in addition to its catabolic functionality study.

The aim of this study is to characterize an isolated transconjugant strain carrying plasmid pJP4 with respect to its (i) 2,4-D degradation activity in a batch culture system and (ii) capability to maintain plasmid in planktonic state in absence of selective pressure. The transconjugant strain used in this study was isolated from a soil bacterial community (Shamsad, 2012). It was hypothesized that (i) the transconjugant strain carrying plasmid pJP4 had 2,4-D degradation capability as genes encoding 2,4-D degradation are located on this plasmid (ii) since pJP4 is relatively large catabolic plasmid, it might become unstable in the transconjugant cells over time in the absence of selective pressure. The catabolic plasmid loss in planktonic cultures might be frequent due to uneven segregation. The lack of fitness cost (energy required for replication) may also cause rapid loss of plasmid from cells. 


\section{Materials and methods}

\section{Media}

Minimum mineral medium (MMN) (Boon et al., 2001) with $1 \mathrm{mM}$ concentration of $\mathrm{NH}_{4} \mathrm{Cl}$ (used as nitrogen source) was used in this experiment. This MMN with $1 \mathrm{mM}(221 \mathrm{mg} / \mathrm{L})$ concentration of 2,4-D (Himedia Laboratories Pvt. Ltd. India) was used as carbon source in the model bioreactor.

\section{Donor, transconjugant and other bacterial cultures}

The strains used in the study were (i) plasmid pJP4 transconjugant strain (Shamsad, 2012) (This transconjugant strain has $97 \%$ similarity with $P$. oryzihabitans), (ii) plasmid pJP4 free transconjugant strain, (iii) donor strain $P$. putida SM1443::gfp2x carrying the plasmid pJP4::dsRed (Christensen et al., 1998, Bathe et al. 2004a, Bathe et al.,2004b), (iv) P. putida ATCC 12633 and (v) E. coli strain (donated by L. Victorio-Walz, Ryerson university) . Plasmid pJP4 (88 $\mathrm{kb}$ in size) is one of the best characterized broad host range catabolic plasmids (Don and Pemberton, 1985) and was isolated by Don and Pemberton, (1981) from the strain Alcaligenes eutrophus JMP123. This plasmid pJP4 encodes tfd genes for the degradation of 2,4 dichlorophenoxyacetic acid (2,4-D).

\section{Ryerson soil (used as a soil microbial community)}

A soil sample was collected from Ryerson University, Toronto, ON and the $15 \%$ glycerol stock of this soil culture was used as source of inoculum (Shamsad 2012).

\section{Generation of plasmid pJP4 free transconjugant strain}

The original transconjugant strain carrying plasmid pJP4 showed plasmid-encoded resistance against gentamicin. Transconjugant cells were grown in 50\% LB medium at room temperature to late exponential phase. At this stage 0.01 volume of the culture was transferred to fresh $50 \%$ LB medium every $24 \mathrm{~h}$. Serial dilutions with PBS (phosphate-buffered saline) of $24 \mathrm{~h}$ incubated 
transconjugant culture were spread on the LB $+25 \mu \mathrm{g} / \mathrm{ml}$ gentamicin plates and LB plates every 24 $\mathrm{h}$ before transferring to fresh 50\% LB medium. After two weeks incubation at room temperature all plates were observed and a beige colony (i.e. a colony not expressing DsRed - mediated pink appearance and red fluorescence) was observed on LB plates. That same colony was restreaked on a $\quad$ LB $+25 \mu \mathrm{g} / \mathrm{ml}$ gentamicin and a LB plate. After $7 \mathrm{~d}$ of incubation, beige colonies and no growth were observed on LB and LB $+25 \mu \mathrm{g} / \mathrm{ml}$ gentamicin plates, respectively. Thus the beige colony was assumed to be a plasmid free transconjugant cell.

Maintenance of donor and transconjugant cultures

The donor strain was maintained on Luria Bertani (LB) agar (Becton Dickinson and company, Sparks, MD, USA) amended with kanamycin $(100 \mu \mathrm{g} / \mathrm{mL})$ and gentamicin $(25 \mu \mathrm{g} / \mathrm{mL})$. The plasmid pJP4 transconjugant strain was maintained on LB agar amended with gentamicin $(25 \mu \mathrm{g} / \mathrm{mL})$. All strains were pre-grown on a $320 \mathrm{rpm}$ rotating shaker at room temperature.

\section{2,4-D degradation in transconjugant batch culture}

Preparation of Batch culture

Batch cultures were prepared in sterile flasks with the pre-grown cultures of all strains mentioned above. All the biomass obtained from these cultures (each of the culture was pelleted by centrifugation for $10 \mathrm{~min}$ at $10,000 \mathrm{~g}$ and washed with $\mathrm{MMN}$ with $1 \mathrm{mM}$ 2,4-D and finally cells were resuspended in MMN with $1 \mathrm{mM}$ 2,4-D and then inoculated in reactors as described by Bathe et al. (2004b) and Bathe et al. (2005). 


\section{2,4-D degradation in batch cultures}

Erlenmeyer flasks were used as model reactors. For this experiment $40 \mathrm{ml}$ MMN with $1 \mathrm{mM} 2,4-\mathrm{D}$ was added to each of the flasks in the experiment set up. Then $4 \mathrm{ml}$ of each of the cultures (centrifuged and resuspended) was used to inoculate to the growth medium in the model bioreactors.

The experiment utilized nine flasks inoculated with (1) no cells (abiotic control), (2) the donor strain P. putida SM1443 carrying the plasmid pJP4, (3) plasmid pJP4 transconjugant strain, (4) P. putida ATCC12633, (5) E. coli strain (6) the donor strain P. putida SM1443 carrying the plasmid pJP4 + a soil microbial community, (7) the plasmid pJP4 transconjugant strain + a soil microbial community, (8) only the soil microbial community and (9) the plasmid free transconjugant strain. The Erlenmeyer flasks of every set up were incubated on a rotary shaker at $320 \mathrm{rpm}$ and room temperature. Mixing and aeration were carried out by continuous shaking on a rotating shaker. The experiment was repeated 3 times (for 3 replicates per treatment).

An additional experiment was carried out to investigate whether or not a nutritional limitation in batch cultures may have led to the cessation of 2,4-D degradation. Three flasks were set up as described above. One flask was inoculated with the plasmid-carrying donor strain, one flask was inoculated with the plasmid-carrying transconjugant strain and finally the third flask was inoculated with $P$. putida ATCC 12633. To minimize the depletion of nutrient sources in the batch cultures, the sample volume removed at the time of sampling was replaced with fresh $\mathrm{MMN}+2,4-\mathrm{D}$ medium. 


\section{2,4-D measurement}

To spectrophotometrically monitor the concentration of 2,4-D, a calibration curve (Appendix B) was prepared at different concentration of 2,4-D $(0.1 \mathrm{mM}, 0.07 \mathrm{mM}, 0.05 \mathrm{mM}, 0.03 \mathrm{mM}$, and 0.01 mM). MMN was used as solvent. The concentration of 2,4-D was measured spectrophotometrically at $230 \mathrm{~nm}$ (Bathe et al., 2004b). For 2,4-D concentration measurements, samples (1 ml from each of the flasks) were collected every $24 \mathrm{~h}$ (up to d 12), diluted ( if UV absorbance was greater than 1.0 for the collected sample- MMN with $1 \mathrm{mM}$ 2,4-D) and filtered ( $0.45 \mu \mathrm{m}$ sterile membrane; Pall Corporation, New quay, Cornwall, UK) and stored at $-20^{\circ} \mathrm{C}$ until further used. 2,4-D concentration was measured spectrophotometrically (Lambda 20, Perkin Elmer, USA) at $230 \mathrm{~nm}$ (Bathe et al., 2004 b). The optical density (OD) of the each cell culture was also measured every $24 \mathrm{~h}$ (up to $12 \mathrm{~d}$ ) by a spectrophotometer at $600 \mathrm{~nm}$. All experimental conditions (all treatments) were tested in triplicate. Experiments were run more than three times to ensure that the results were replicable.

\section{Plasmid (pJP4) stability experiment in planktonic transconjugant cells}

\section{Growth curve of transconjugant strain}

Growth curve of the transconjugant strain was generated by the culture grown in $40 \mathrm{ml} 50 \% \mathrm{LB}$ medium. Optical Density (OD) was taken at different time intervals ( every $2 \mathrm{~h}$ over a $12 \mathrm{~h}$ period and then after 20 h, 21 h, 22 h, 23 h, 24 h, 25 h, 26 h, 27 h, 28 h, 29 h, 30 h, 31 h and 32 h) by spectrophotometer at $600 \mathrm{~nm}$ and these readings were plotted against time to construct a growth curve to determine the late exponential phase. Generation time (based on absorbance reading over time as described by Widdel (2007) of the plasmid pJP4 transconjugant strain was also calculated (Fig. 3.3). 


\section{Detection of plasmid carrying cells}

Transconjugant cells were grown in $50 \% \mathrm{LB}$ medium at room temperature to late exponential phase. At this stage 0.01 volume of the culture was transferred to fresh 50\% LB medium every 24 h. Plasmid carrying cells (transconjugant cells carry $d s R e d$ tagged plasmid and express DsRed fluorescence) were detected every $24 \mathrm{~h}$ by using confocal laser scanning microscopy (Zeiss LSM510; Zeiss, Jena, Germany) at $543 \mathrm{~nm}$ excitation wavelength before transferring to fresh $50 \%$ LB medium. DsRed was also detected by performing standard plate on the LB $+25 \mu \mathrm{g} / \mathrm{ml}$ gentamicin plates and LB plates. Serial dilutions with PBS (phosphate-buffered saline) of $24 \mathrm{~h}$ incubated transconjugant culture were spread on the LB $+25 \mu \mathrm{g} / \mathrm{ml}$ gentamicin plates and LB plates every $24 \mathrm{~h}$ before transferring to fresh $50 \% \mathrm{LB}$ medium. All colonies on the $\mathrm{LB}+25 \mu \mathrm{g} / \mathrm{ml}$ gentamicin plates and LB plates were counted (day 3, 7, 10 and 14) and pink colonies (DsRed fluorescing transconjugant colonies) were observed on both types of plates during two weeks of incubation at room temperature. During the two week incubation period colonies that grew on the plates were checked for DsRed fluorescence using a Leica fluorescence dissection microscope (Leica Microsystems, Concord, ON, Canada) and compared with a positive control plate of transconjugant colonies. Plasmid carrying cells were identified by microscopy. Total cells and transconjugant cells carrying plasmid were enumerated manually and expressed as a \% of total cells. The $\%$ of plasmid carrying cells was also determined by spread plate counts. The ratio of transconjugant cells (enumeration of plasmid carrying transconjugant cells on $\mathrm{LB}+25 \mu \mathrm{g} / \mathrm{ml}$ gentamicin plates) to the total number of cells (enumeration of cells on LB plates) was determined and expressed as \%). Experiments were terminated after $12 \mathrm{~d}$.

All experimental conditions were tested in triplicate. More than ten confocal laser scanning microscopy (CLSM) images were generated every $24 \mathrm{~h}$ to detect and enumerate plasmid carrying transconjugant cells. The experiment was run more than three times to ensure that the results were replicable. 


\section{Statistical Analysis}

Standard deviations were calculated using excel (Microsoft $\left.{ }^{\circledR}\right)$. For the analysis of 2, 4-D degradation trend, each measured 2,4-D concentration value of the all reactors over time was added by 1 then converted to corresponded logarithm values (to avoid negative values) for the conspicuous representation in the graph (Fig.3.2). Same method of calculation was also followed for the growth curve of all strains (Fig. 3.3).

\section{Results}

\section{2,4-D degradation experiment}

All the reactors were operated under batch conditions. Batch operation was performed to produce biomass and to allow maximum contact of inoculum and 2,4-D for biodegradation. The courses of the 2,4-D concentrations (trend of biodegradation) in the model reactors are shown in Fig. 3.1. The extent of 2,4-D degradation values (OD at $230 \mathrm{~nm}$ measurements) varied depending on the types of strain used.

In abiotic control reactors (having no cells), the concentration of 2,4-D was measured. In these control reactors, biodegradation did not occur as OD measurements at 230 remained constant for the duration of the experiment (Fig. 3.1). The plasmid pJP4 transconjugant cells degraded most of the initially added 2,4-D within 12 d. The donor strain P. putida SM1443 caused a rapid degradation up to day 5 and then showed a slower degradation in comparison to the transconjugant strain. P. putida ATCC 12633 caused a slow decrease of 2,4-D concentration during the experimental period and was less effective in reducing 2,4-D concentration than all other biomass containing flasks, with the exception of E. coli and plasmid free transconjugant strain. E. coli and the plasmid free 
transconjugant were not able to degrade 2,4-D and the degradation trend was almost close to the abiotic control treatment (Fig. 3.1).

The 2,4-D degradation trend (Fig. 3.1) by the sole transconjugant strain, the donor strain with a soil microbial community and the transconjugant strain with a soil microbial community were almost identical up to day 3 . But the donor strain with a soil microbial community and the transconjugant strain with a soil microbial community caused a slightly slower decrease of 2,4-D in comparison to the transconjugant strain after day 5. The soil microbial community by itself caused slower decrease of 2,4-D than the soil microbial community amended with either the donor or transconjugant strain (Fig. 3.1). 


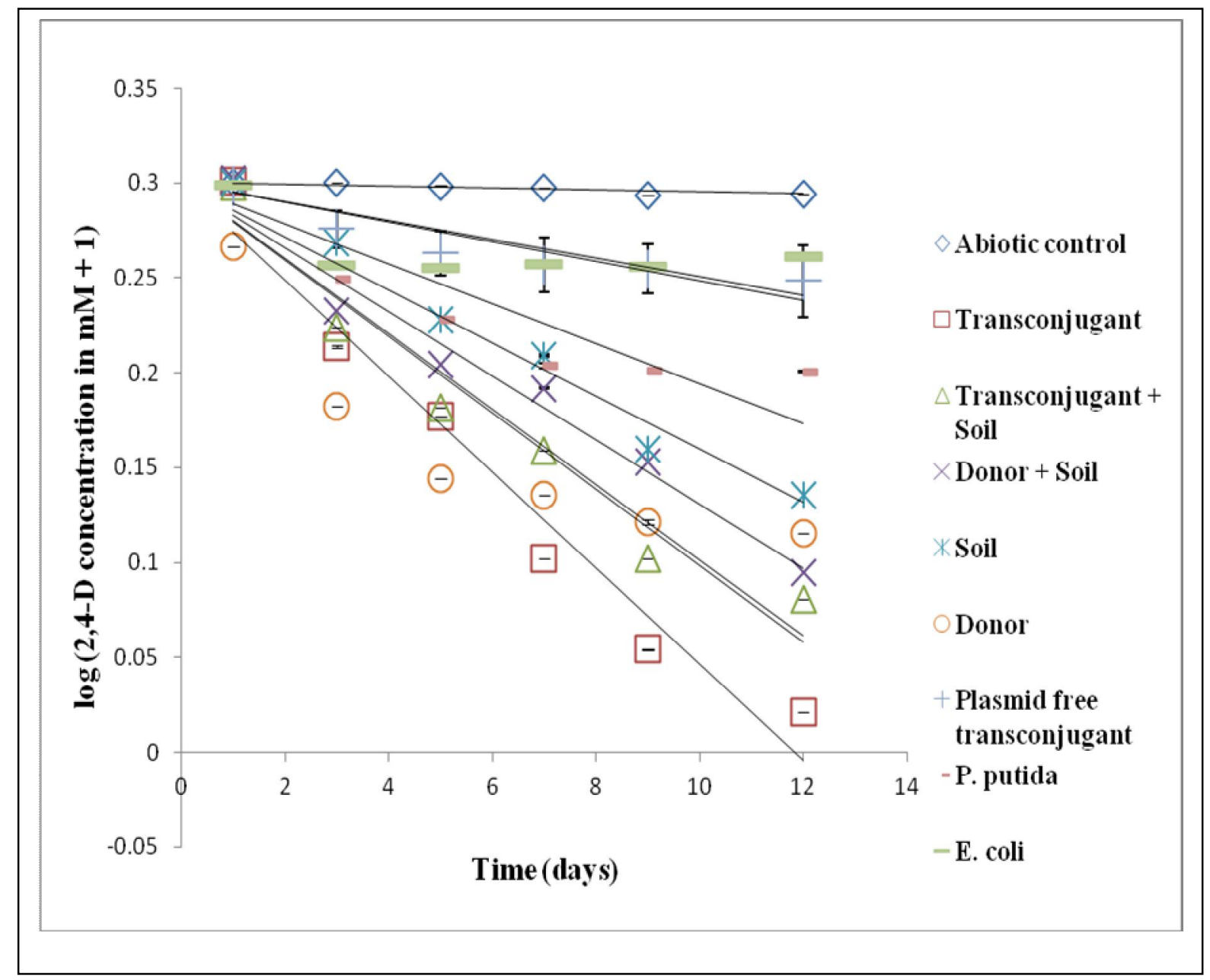

Fig.3.1: 2,4-D concentration over time in batch cultures inoculated with plasmid pJP4 transconjugant strain in comparison to the plasmid donor strain, plasmid-free transconjugant strain, P. putida strain ATCC12633, E. coli strain, a soil derived microbial community and an abiotic control. Trend lines (with a common y-intercept at time zero reflecting the same starting concentration) are shown. Error bars represented the standard deviation of triplicate samples. 
The optical density (OD) of the cell cultures of model bioreactors was measured by spectrophotometer at $600 \mathrm{~nm}$ (Fig. 3.2) to observe the relationship between the bacterial biomass present in the reactors and their 2,4-D degradation trend.

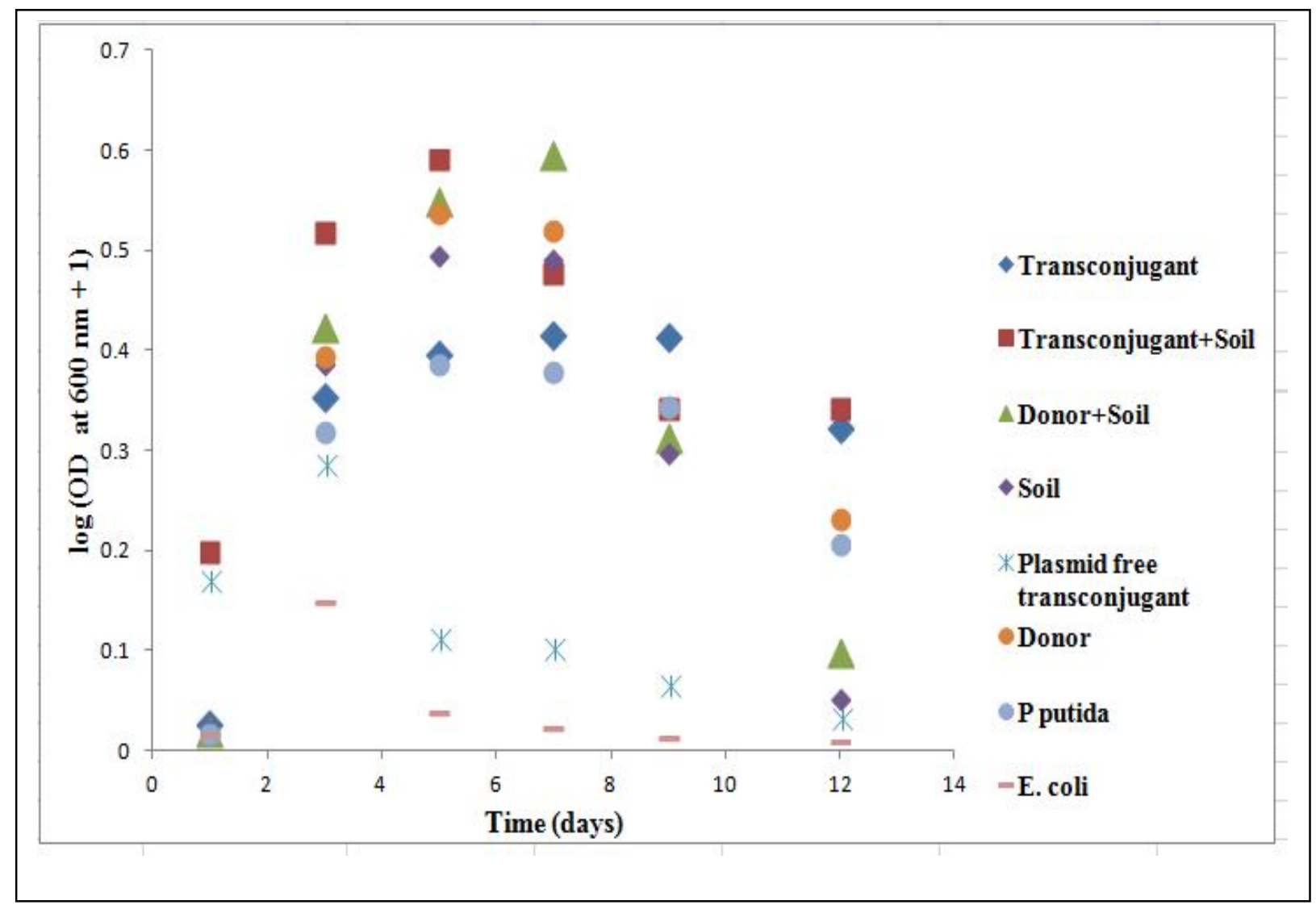

Fig. 3.2: OD measurement (at $600 \mathrm{~nm}$ ) of different cultures over time used in degradation reactors containing $\mathrm{MMN}+2,4-\mathrm{D}(1 \mathrm{mM})$ 
pJP4 plasmid stability

The stability of pJP4 plasmid in transconjugant cells was evaluated by growing cells in $50 \%$ LB medium in the absence of selective pressure for up to 60 generations (the generation time was $2 \mathrm{~h}$, calculated from growth curve (Fig. 3.3). There was a rapid loss of pJP4 plasmid in planktonic cultures over time. Microscopic (CLSM) results shown in Fig. 3.4 indicated that plasmid was lost from over $70 \%$ of the planktonic transconjugant cells within 24 generations, after which almost complete loss of plasmid (>99\%) rapidly occurred within the next 24 generations. From the microscopic observation, it was found that plasmid was expressed in $100 \%$ transconjugant cells up to 24 generations. Loss of the pJP4 plasmid was observed later (after 24 generations) in planktonic cultures in the absence of selective pressure. At 60 generations there was no plasmid found in the planktonic transconjugant cells. Microscopic results were verified by performing standard plating on LB agar plates with and without gentamicin (Table. 3.1). It was observed that plasmid was still maintained in most transconjugant cells on $\mathrm{LB}+25 \mu \mathrm{g} / \mathrm{ml}$ gentamicin plates at 48 generations (Fig. 3.5-a) and exhibited DsRed mediated bright fluorescence (using a fluorescence dissection microscope). At 60 generations, light pink colonies were observed on the both plates (Fig. 3.5-b and c), checked for DsRed mediated bright fluorescence by using a fluorescence dissection microscope and did not display the expected fluorescence. The plasmid pJP4 transconjugant strain maintained on LB agar plate amended with gentamicin $(25 \mu \mathrm{g} / \mathrm{mL})$ was used as control. 


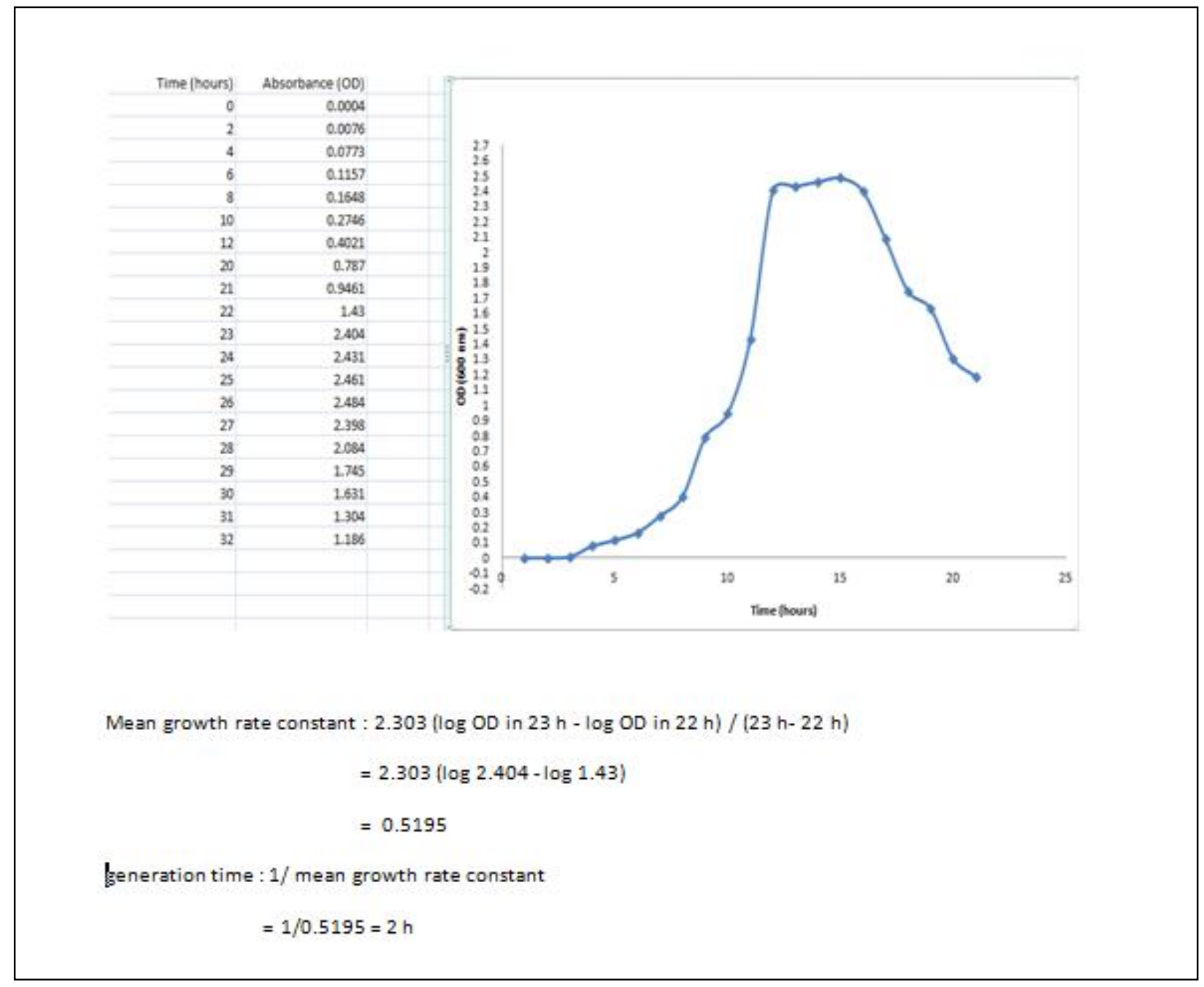

Fig. 3.3 Growth curve of the plasmid pJP4 transconjugant strain and generation time determination (Widdel, 2007) 


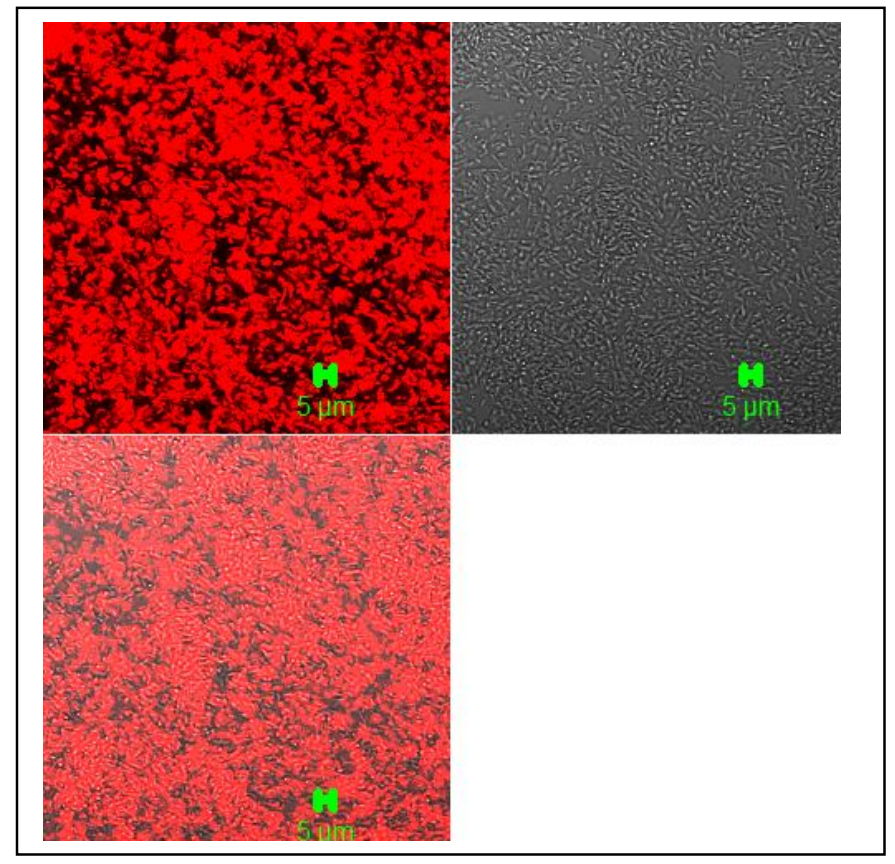

(a)

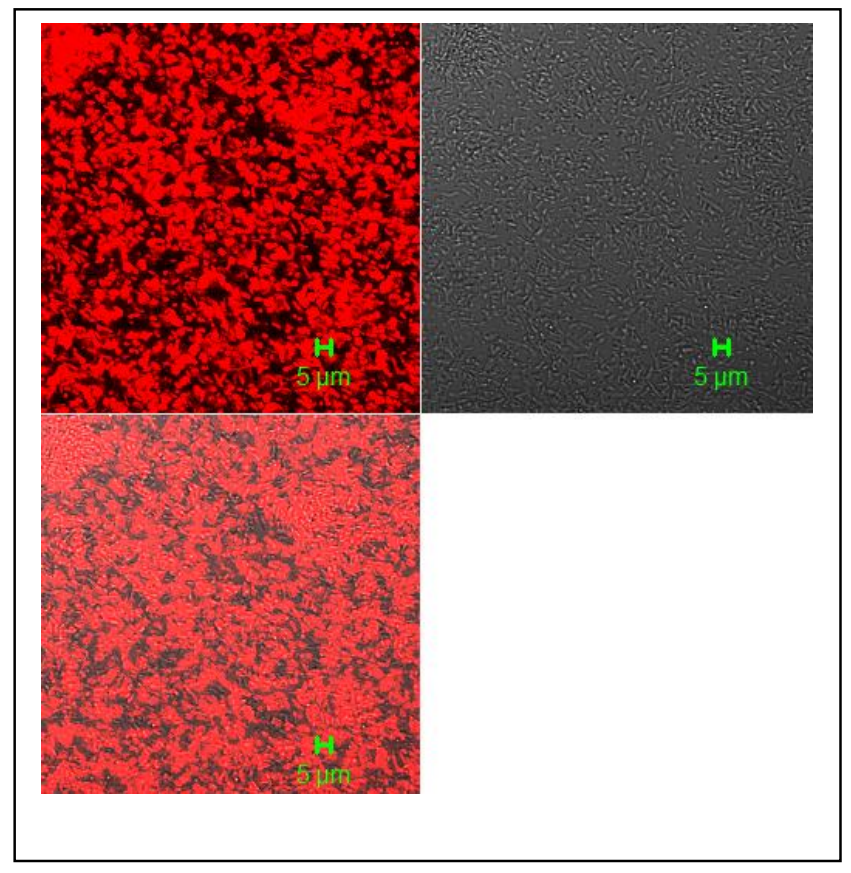

(c)

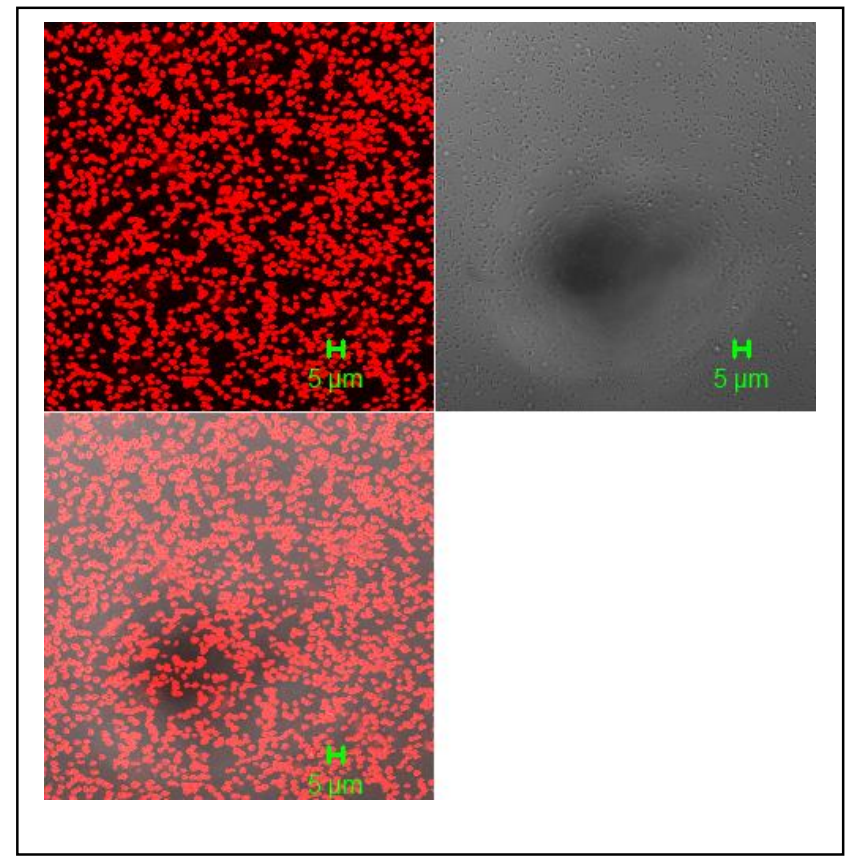

(b)

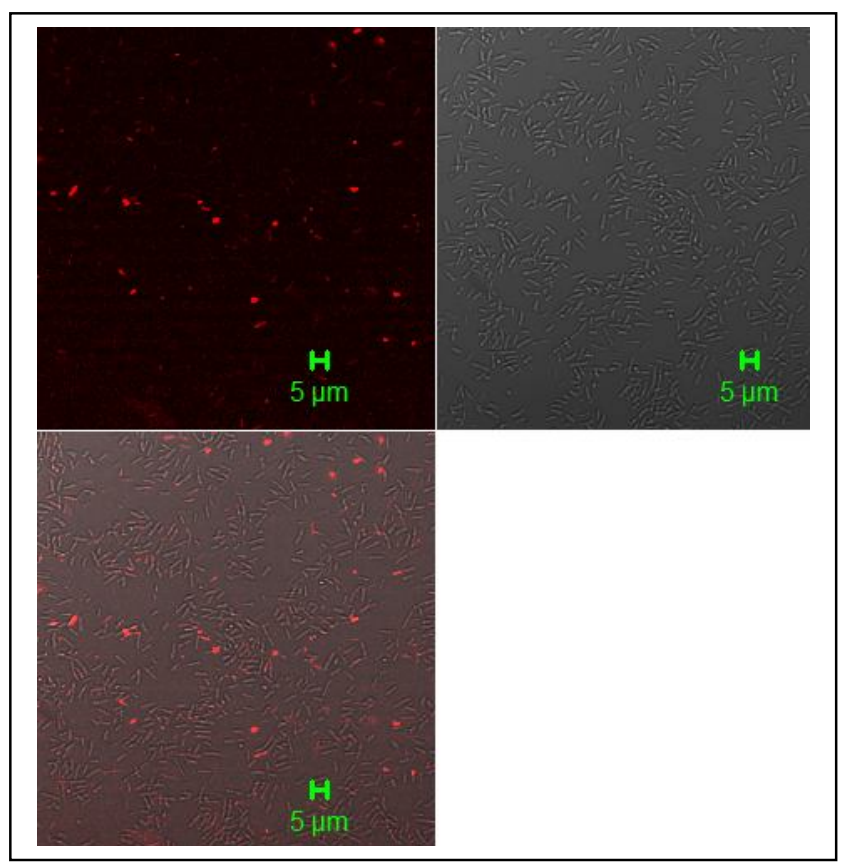

(d) 


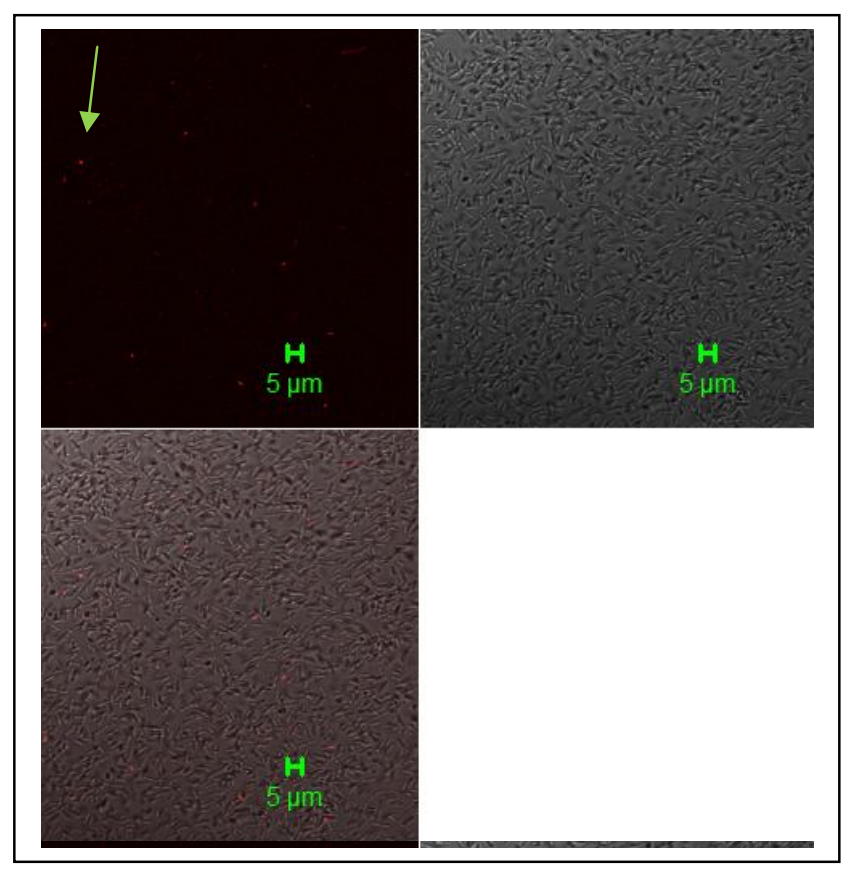

(e)

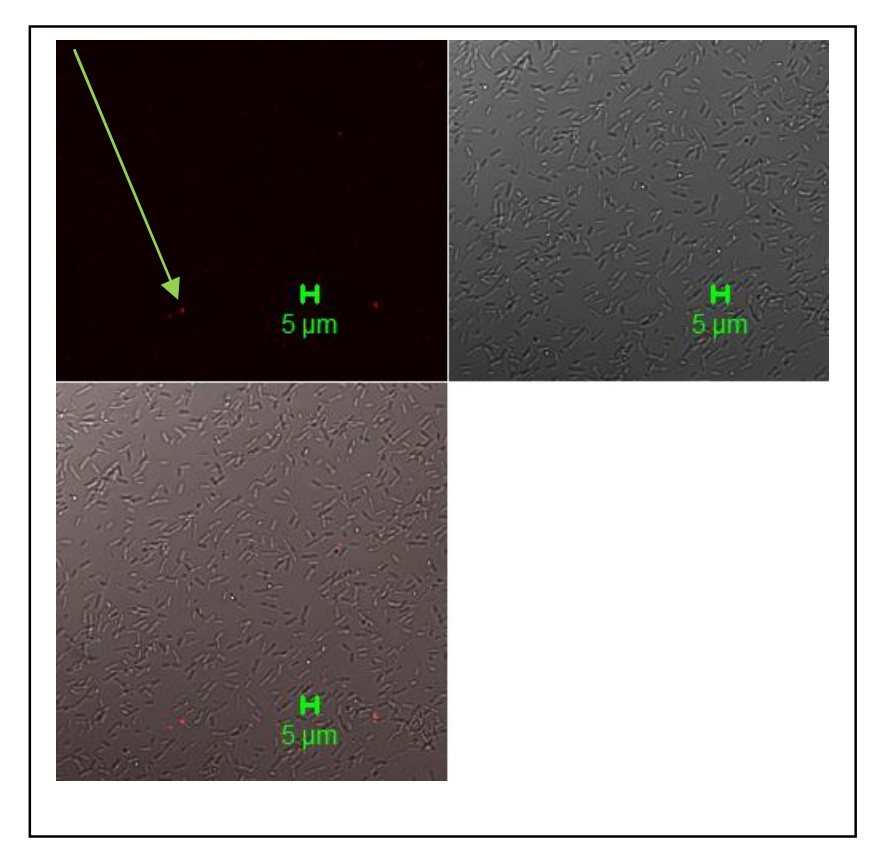

(f)

Fig. 3.4: Microscopic (CLSM) detection of pJP4 plasmid in planktonic cultures over time at $543 \mathrm{~nm}$ excitation wavelength. Transconjugant cells carrying DsRed tagged plasmid pJP4 expressed red fluorescence and non-florescent cells represented transconjugant cells without a plasmid (a) CLSM image of positive control of transconjugant cells expressing DsRed (used as DsRed detection control) (b) CLSM image after $0 \mathrm{~h}$ (plasmid was maintained in $100 \%$ transconjugant cells) (c) CLSM image after $24 \mathrm{~h}$ (12 generations) (plasmid was maintained in $100 \%$ transconjugant cells) (d) CLSM image after $48 \mathrm{~h}$ (24 generations) (plasmid was maintained in $29 \%$ transconjugant cells (e) CLSM image after $72 \mathrm{~h}$ (36 generation) (plasmid was maintained in $<4 \%$ transconjugant cells) (f) CLSM image after 96 $\mathrm{h}$ (48 generations) (plasmid was maintained in $<1 \%$ transconjugant cells). Arrows in images (e) and (f) indicated the presence of a few transconjugant cells expressing DsRed fluorescence. 
Table. 3.1: Enumeration of plasmid carrying transconjugant cells by microscopy and spread plate

\begin{tabular}{|c|c|c|c|c|}
\hline Generations & $\begin{array}{l}\text { CFU } / \mathrm{mL} \text { (LB } \\
+25 \mu \mathrm{g} / \mathrm{ml} \text { gentamicin } \\
\text { plates) }\end{array}$ & $\begin{array}{l}\text { CFU/mL (LB } \\
\text { plates) }\end{array}$ & $\begin{array}{l}\% \text { of plasmid carrying } \\
\text { transconjugant cells } \\
\text { detected by spread plate } \\
\text { (ratio of cells carrying } \\
\text { plasmid pJP } 4 \text { on LB }+ \\
25 \mu \mathrm{g} / \mathrm{ml} \text { gentamicin } \\
\text { plates to the total cells } \\
\text { on LB plates) }\end{array}$ & $\begin{array}{l}\% \text { of plasmid } \\
\text { carrying } \\
\text { transconjugant cells } \\
\text { detected by CLSM } \\
\text { (ratio of plasmid pJP4 } \\
\text { carrying cells to the } \\
\text { total cells ) }\end{array}$ \\
\hline 0 & $9.2 \times 10^{6}$ & $3.7 \times 10^{7}$ & $25 \%$ & $\begin{array}{l}100 \% \\
\text { (plasmid in all } 941 \\
\text { transconjugant cells) }\end{array}$ \\
\hline 12 & $4.6 \times 10^{6}$ & $1.5 \times 10^{8}$ & $3 \%$ & $\begin{array}{l}100 \% \\
\text { (plasmid in all } \\
\text { (TMTC) } \\
\text { transconjugant cells) }\end{array}$ \\
\hline 24 & $9.5 \times 10^{5}$ & $5.3 \times 10^{7}$ & $1.8 \%$ & $\begin{array}{l}29 \% \\
\text { (plasmid in } 102 \\
\text { transconjugant cells } \\
\text { out of } 347 \text { total cells) }\end{array}$ \\
\hline 36 & $7.6 \times 10^{5}$ & $1.1 \times 10^{8}$ & $0.7 \%$ & $\begin{array}{l}3.5 \% \\
\text { (plasmid in } 12 \\
\text { transconjugant cells } \\
\text { out of } 341 \text { total cells) }\end{array}$ \\
\hline 48 & $9.7 \times 10^{5}$ & $8.1 \times 10^{8}$ & $0.12 \%$ & $\begin{array}{l}0.7 \% \\
\text { (plasmid in } 3 \\
\text { transconjugant cells } \\
\text { out of } 385 \text { total cells) }\end{array}$ \\
\hline 60 & $3.2 \times 10^{5}$ & $1.2 \times 10^{9}$ & $0.026 \%$ & $0 \%$ \\
\hline
\end{tabular}




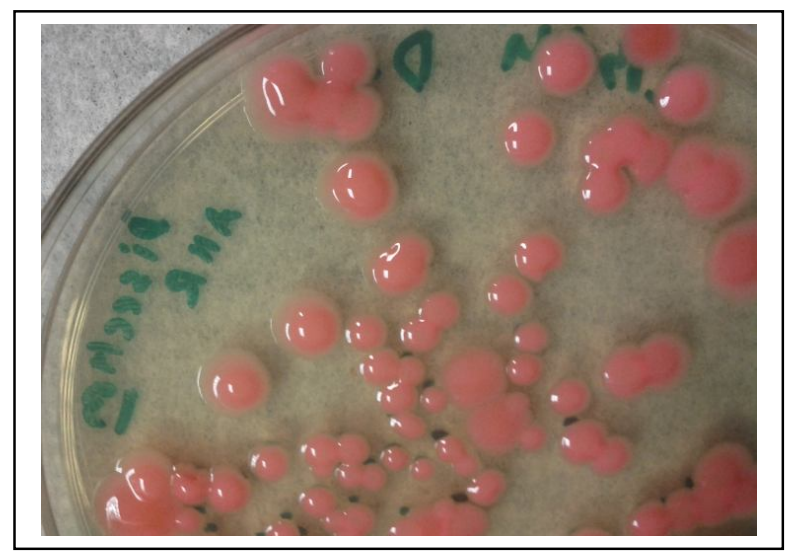

(a)
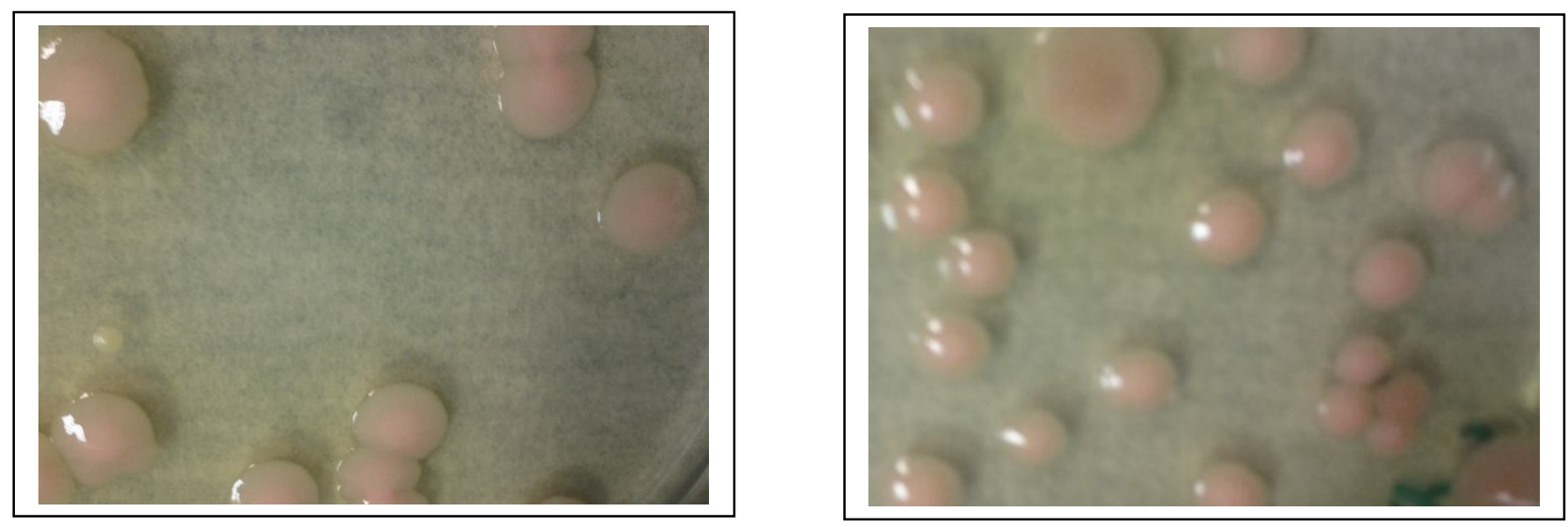

(b)

(c)

Fig. 3.5: Detection of plasmid pJP4 by visual observation on the LB + gentamicin plates and LB plates (a) plasmid pJP4 transconjugant cells (approx. 5-10 $\mathrm{mm}$ in diameter) on the $\mathrm{LB}+25 \mu \mathrm{g} / \mathrm{ml}$ gentamicin plate at 48 generations $(96 \mathrm{~h}$ ) after $9 \mathrm{~d}$ incubation (b) transconjugant cells on the LB + $25 \mu \mathrm{g} / \mathrm{ml}$ gentamicin plate at 60 generations $(120 \mathrm{~h})$ after $8 \mathrm{~d}$ incubation $(\mathrm{d})$ transconjugant cells on the LB plate at 60 generations $(120 \mathrm{~h})$ after $8 \mathrm{~d}$ incubation. 


\section{Discussion}

Results showed in Fig. 3.1 indicated the transconjugant strain caused rapid drop of 2,4-D concentration within the first $3 \mathrm{~d}$ and after day 12 the reactor containing the plasmid pJP4 transconjugant strain contained less than $5 \%$ of the initial 2,4-D (1 mM). The donor strain, a soil microbial community and P. putida strain as well as the transconjugant strain without a plasmid pJP4 containing reactors contained $30 \%, 37 \%, 60 \%$ and $80 \%$ respectively of the initial 2,4-D after day 12 .

Both the donor (Bathe et al., 2004b) and transconjugant strain (Shamsad, 2012) carry catabolic plasmid pJP4 and this plasmid encodes the tfd genes that confer the ability to degrade 2,4-D. The genus Pseudomonas (Gram-negative, rod shaped aerobic bacteria and isolated from soils) having versatile metabolic activity might degrade (to some extent) toxic pollutants containing benzene, toluene, ethyl benzene and xylenes (Fujii et al., 1997, Bettman and Rehm, 1984). In environments, a soil microbial community might tolerate environmental stresses and show natural degradation ability to a range of compounds up to a certain extent (Top et al., 2002). E. coli did not grow (Fig. 3.2) in the reactor as (i) it was not able to use 2,4-D as carbon source (ii) it is not a naturally soil borne microorganism and may be more susceptible to environmental stresses (Newby et al., 2000). The transconjugant strain possessing degradative plasmid pJP4 carried functional phenotypes to degrade 2,4-D significantly in all treatments and the transconjugant strain without a plasmid showed a very low 2,4-D degradation trend (close enough to equal to abiotic treatment showed in Fig.3.1). The negligible 2,4-D degradation trend by $E$. coli and plasmid free transconjugant, has re-established that plasmid pJP4 plays an important role for the successful implementation of genetic bioaugmentation. 
Shamsad (2012) observed slightly enhanced degradation of 2,4-D in soil-derived mixed cultures amended with the donor strain $P$. putida SM1443::gfp2x carrying the plasmid pJP4::dsRed than the control (with no plasmid carrying cells) in a batch culture experiment. Bathe et al. (2004b) showed $90 \%$ degradation of $2,4-\mathrm{D}$ in the bioaugmented reactor by the same donor strain $P$. putida SM1443 within $40 \mathrm{~h}$. On the other hand, a control reactor with no plasmid degraded only $40 \%$ of the initial 2,4-D concentration after $90 \mathrm{~h}$ of operation. Quan et al. (2010) used the same donor strain for their bioaugmentation experiment. They found that 2,4-D (initial concentration was $160 \mathrm{mg} / \mathrm{L}$ equivalent to $0.7 \mathrm{mM}$ ) was completely removed in the bioaugmented system within $62 \mathrm{~h}$, while the control system containing no donor strain only removed 26\% within $66 \mathrm{~h}$.

For the comparison of 2,4-D degradation between different types of planktonic bacterial cells used in this study and to check for the possibility of volatility and auto-degradation such as photo-oxidation of 2,4-D used, the control reactors were prepared without cells. No 2,4-D concentration decrease was observed in the control reactor indicating that 2,4-D volatilization or abiotic degradation did not cause 2,4-D loss.

Both donor strain and transconjugant strain carry catabolic plasmid pJP4 but donor strain had less 2,4-D degradation capability as compared to transconjugant strain (Fig. 3.1) up to the entire experiment period. Genetic bioaugmentation mostly depends on the occurrence of transconjugants acquiring contaminant biodegradation functionality rather than donor colonization (Ikuma and Gunch, 2012). There might have phylogenetic distance between the donor and transconjugant strain for the phenotype functionality of catabolic plasmid (Ikuma and Gunch, 2012) and that might limit the expression level of genes present in the plasmid donor. Phylogeney is directly correlated to genomic guanine-cytosine content (Muto and Osawa, 1987). Ikuma and Gunch, (2012) observed that enzymatic activities as well as degradation 
functionality were significantly higher in the strains with higher guanine-cytosine content in some cases.

Greater decrease of the initial 2,4-D concentration was observed in the reactor with donor strain + a soil microbial community (Fig. 3.1) as compared to the reactor with single donor strain till day 12. It could be assumed that mixed cultures might improve microbial activity and stability as compared to single culture (Ambujom, 2001). Plasmid transfer event from donor to soil microbial community might occur in reactor and facilitate 2,4-D degradation to a higher extent (Fig. 3.1). But interestingly, the improved degradation trend was not observed in the reactor with plasmid containing transconjugant cells + a soil microbial community (Fig. 3.1) as compared to the reactor containing plasmid containing transconjugant cells only. The experimental conditions might not facilitate the transconjugant strain to a greater extent to act as plasmid donor. Plasmid pJP4 transconjugant might be more effective in degrading 2,4-D when grown as pure culture as compared to when co-cultured with soil microbial community. Probable reason might be due to competition for nutrients and space between transconjugant cells and soil microbial community. In future follow-up experiments could be conducted to determine if the plasmid pJP4 transconjugant strain serves as plasmid donor to efficiently enhance genetic bioaugmentation in the environmental contaminated samples.

Fig. 3.1 and Fig. 3.2 showed the relationship between bacterial biomass and 2,4-D degradation trend. E. coli and plasmid free transconjugant strain containing reactor showed a little degradation of 2,4-D and the culture also had little growth and collapsed after day 3. E. coli (not a soil bacterium) and plasmid pJP4 free transconjugant were not able to tolerate the presence of 2,4-D. In contrast, plasmid pJP4 transconjugant cells grew well in reactor containing 2,4-D and were able to effectively degrade the 2,4-D contaminant. Soil bacterium P. putida showed the 
ability to tolerate environmental stress imposed by 2,4-D. From these observations it can be said that differences between these bacteria may relate to tolerance (i.e. transconjugant and $P$. putida's ability to withstand 2,4-D versus $E$. coli's sensitivity) rather than differences in degradation capacity of the two bacteria, especially.

Fig 3.1 and 3.2, and also showed that transconjugant cells in the reactors did not completely degrade 2,4-D (where the OD at $230 \mathrm{~nm}$ was zero) over the experiment period and the degradation rate became slower after day 8 of the experiment, though there were transconjugant cells present in the reactors. Degradation might stop before complete depletion of 2,4-D in reactors due to the limitation of a key nutrient such as nitrogen. During batch experiments, some nutrients could be depleted with time. Sometimes the lack of nitrogen source in the medium might result in decreased growth rate of cells (Russell and Cook 1995, Sensez, 1962) which might affect phenotype functionality of the cells. To test the possibility that depletion of nutrients in the batch cultures may have resulted in inhibition of 2,4-D degradation, an experiment was carried out with three reactors (the donor, transconjugant and P. putida strain). To minimize the depletion of nutrient sources in the batch cultures, the sample volume removed at the time of sampling was replaced with fresh $\mathrm{MMN}+2,4-\mathrm{D}$ medium. But no remarkable change in degradation trend of 2,4-D was observed (data not shown). Daugherty and Karle, (1994) observed that the rate of 2,4-D degradation might be affected by the presence of succinate (end product of 2,4-D degradation) and it became a dominant factor at low ratio of 2,4D to succinate in the feed. They also gave an alternate explanation. Low concentration of 2,4-D in the feed might lead to a lack of induction of the catabolic enzymes mediated by tfd genes regulation. 
The stability of a catabolic plasmid in transconjugant cells seems not only to ensure the successful implementation of genetic bioaugmentation over a longer period of time but also can influence the microbial community with respect to their long-term effect in the pollutant site.

It is very hard to identify actual plasmid loss in real time and therefore the common practice is to look at the ratio between plasmid free cells and plasmid carrying cells over time and use this ratio as the frequency of plasmid loss (Madsen et al., 2013). In the absence of selective pressure, plasmid was maintained in the $100 \%$ transconjugant cells till 12 generations (Fig 3.4 and Table. 3.1). Microscopically (CLSM), no plasmid was detected in transconjugant cells after 60 generations. Madsen et al. (2013) described that plasmid would eventually become completely lost from planktonic cultures over time (as there is no inactive layer in planktonic cultures like biofilms to maintain plasmids for longer period). Ponciano et al. (2007) outlined that the stability of a plasmid in a host strain might depend on the metabolic burden (energy required for plasmid replication) of the plasmid on the host cell. In planktonic transconjugant cells, the rate of plasmid loss over time is high (Madsen et al., 2012). When bacterial activity is high and cell division occurs frequently that ultimately might potentiate the rate of plasmid loss due to the increased metabolic burden for plasmid maintenance in planktonic cells (O'Connell et al., 2006). In our study it was observed that under no selective pressure, no transconjugant cell was able to maintain plasmid in their cells over 48 generations (Fig. 3.4 and Table 3.1). IKuma and Gunch, 2012 observed that the stability of catabolic TOL plasmid in transconjugants might be strain specific and in the absence of selective pressure catabolic plasmid is highly unstable. In a previous study (Kinkle et al., 1993) it was also seen that pJP4 is a relatively large plasmid and it might be unstable in host cells under non selective conditions. Fig. 3.5 (a) showed that there was a presence of plasmid in almost transconjugant 
cells on $\mathrm{LB}+25 \mu \mathrm{g} / \mathrm{ml}$ gentamicin plates ( $9 \mathrm{~d}$ incubation) as compared to microscopy counterparts at 48 generations. it might be due to the presence of selective pressure and long incubation time applied for LB $+25 \mu \mathrm{g} / \mathrm{ml}$ gentamicin plates. Simonsen (1990) hypothesized that most transconjugant cells received the plasmid from another transconjugant cell when plasmid transfer and growth of transconjugant cells were monitored in agar surface media. At 60 generations, light pink colonies were observed on the both plates after $8 \mathrm{~d}$ of incubation (Fig. $3.5 \mathrm{~b}$ and c). But these colonies did not display expected DsRed fluorescence when viewed with dissection microscope with fluorescence capabilities. But after $15 \mathrm{~d}$ of incubation, bright pink colonies on these both plates (compared with a positive control plate of transconjugant cells) were observed but few pink colonies exhibited expected DsRed fluorescence when checked by fluorescence dissection microscope (data not shown). The reason might be that non-plasmid transconjugant cells might grow faster than plasmid transconjugant cells on LB plates and show false phenotype (by visual inspection) attached to plasmid containing transconjugant cells after a long incubation period. There was a possibility that on the LB $+25 \mu \mathrm{g} / \mathrm{ml}$ gentamicin plates, due to having low expression level of genes on the plasmid pJP4, the concentration of gentamicin was not enough to create sufficient selective pressure to maintain the plasmid in transconjugant cells. Such assumptions would need to be tested in future experiments as there was no support for these speculations. Additionally, this experiment should be repeated using another plasmid pJP4-carrying strain, such as the donor, as control. This would indicate if plasmid loss is strain specific.

Beige colony from the LB plates were replicated on new gentamicin LB $+25 \mu \mathrm{g} / \mathrm{ml}$ gentamicin and LB plates. After $7 \mathrm{~d}$ of incubation, there were beige colonies seen on LB plates and no growth found on $\mathrm{LB}+25 \mu \mathrm{g} / \mathrm{ml}$ gentamicin. It might confirm the presence plasmid free transconjugant cells grown on LB plates. 
In conclusion, it can be said that enhanced degradation trend ( $\geq 95 \%)$ of 2,4-D was observed by plasmid pJP4 transconjugant strain in comparison to the donor strain $P$. putida carrying plasmid pJP4, P. putida ATCC 12633, a soil microbial community and the transconjugant strain without a plasmid in the degradation study. It was also observed plasmid was lost from almost $70 \%$ of the transconjugant cells within 24 generations in the absence of selective pressure. 


\section{CHAPTER 4: CONCLUSIONS AND FUTURE RECOMMENDATIONS}

The first object of this research work was to determine the transfer of plasmid pJP4 in a model donor and single recipient biofilm in absence of selective pressure. The pJP4 plasmid was transferred to recipient cells in both plate mating and flow cell experiment and red fluorescent protein DsRed (transfer of plasmid) was detected in the mating patch and in biofilm developed in the flow cell experiment. Using P. putida ATCC 12633 as a recipient (other than mixed soil microbial community) simplified plasmid transfer methods and provided information to detect plasmid pJP4 transfer in absence of selective pressure. The model donor P. putida SM1443::gfp2x carrying the plasmid pJP4::dsRed was capable of transferring plasmid pJP4 to the single recipient biofilm.

The second objective of this study was to investigate 2,4-D degradation capability of plasmid pJP4 transconjugant (isolated from a soil microbial community) in a batch culture system. The transconjugant strain carrying plasmid pJP4 exhibited a functional degradative phenotype. The $t f d$ gene located on the plasmid pJP4 encoded 2,4-D degradation. In the batch culture experiment, greater degradation capability $(\geq 95 \%)$ of $2,4-\mathrm{D}$ was observed with plasmid pJP4 transconjugant strain than either the donor strain $P$. putida carrying plasmid pJP4, P. putida ATCC 12633 without a plasmid pJP4, a soil microbial community or the transconjugant strain without a plasmid.

The third objective of our research was to evaluate the stability of the plasmid pJP4 in planktonic transconjugant cells under non-selective pressure condition. There was a rapid plasmid loss in planktonic cultures in absence of selective pressure. It might be due to either uneven segregation of plasmid or lack of fitness cost (energy required for replication) of maintaining plasmid. The plasmid was lost from almost $70 \%$ of the transconjugant population within 24 generations. 
The results of plasmid pJP4 stability in planktonic transconjugant cells in addition to their 2,4D degradation functionality might be a useful to study the successful implementation of plasmid pJP4 mediated bioaugmentation (genetic bioaugmentation) in the environmental samples in future.

The future work may include the following experiments: (i) Plasmid pJP4 is a well characterized plasmid that encodes catabolic genes for the degradation of 2,4-D. For the future plasmid transfer event to host cells, only GFP detection method by epifluorescent microscopy or CLSM can be used. The donor strain will carry a $g f p$ tagged plasmid pJP4. GFP fluorescence will be repressed in the donor cell but will be expressed to the host transconjugant cells. Upon transfer of catabolic plasmid pJP4 to host cells, the transconjugant cells will be microscopically detected through visualization of green fluorescence. In addition, GFP fluorescence can be used to detect a transconjugant from flow chamber effluent samples if needed. (ii) The capability of the plasmid pJP4 transconjugant strain to serve as plasmid donor and 2,4-D degradation by this transconjugant in biofilm system can be studied. Isolation and characterization of the transconjugant strain without plasmid pJP4 (detected by spread plate in the plasmid stability study) by $16 \mathrm{~S}-\mathrm{rRNA}$ sequencing can also be conducted. Concentration of 2,4-D can be measured either by high performance liquid chromatography (HPLC) or gas chromatography (GC). Measurement of 2,4-D might be more accurate by HPLC method in comparison to spectrophotometric determination of 2,4-D. HPLC might be able to separate 2,4-D degradation intermediates and end products (if present in the bioreactors). (iii) To study the plasmid pJP4 stability of transconjugant cells in biofilms (in environments bacteria are believed to mainly reside biofilms) in the presence and absence of selective pressure (2,4-D). Over a longer period of time plasmids might be sustained in biofilms ( due to have a spatially structured community and EPS mediated protection from surrounding stresses) than in a planktonic culture. 
CHAPTER 5: APPENDICES

Appendix A: Composition of MMN medium

MMN - phosphate buffer $100 \times($ Boon et al., 2001)

$\mathrm{Na}_{2} \mathrm{HPO}_{4}$

$141.96 \mathrm{~g} / \mathrm{L}$

$\mathrm{KH}_{2} \mathrm{PO}_{4}$

$136.09 \mathrm{~g} / \mathrm{L}$

MMN salt solution $200 \times($ Boon et al., 2001)

$\mathrm{MgSO}_{4}$

$19.70 \mathrm{~g} / \mathrm{L}$

$\mathrm{CaCl}_{2} \cdot 2 \mathrm{H}_{2} \mathrm{O}$

$1.18 \mathrm{~g} / \mathrm{L}$

$\mathrm{H}_{3} \mathrm{BO}_{3}$

$0.23 \mathrm{~g} / \mathrm{L}$

$\mathrm{FeSO}_{4} .7 \mathrm{H}_{2} \mathrm{O}$

$0.56 \mathrm{~g} / \mathrm{L}$

$\mathrm{ZnSO}_{4} .7 \mathrm{H}_{2} \mathrm{O}$

$0.23 \mathrm{~g} / \mathrm{L}$

$\mathrm{MnSO}_{4} .7 \mathrm{H}_{2} \mathrm{O}$

$0.34 \mathrm{~g} / \mathrm{L}$

$\mathrm{CuSO}_{4} .5 \mathrm{H}_{2} \mathrm{O}$

$0.08 \mathrm{~g} / \mathrm{L}$

$\mathrm{CoCl}_{2} \cdot 6 \mathrm{H}_{2} \mathrm{O}$

$0.05 \mathrm{~g} / \mathrm{L}$

$\mathrm{Na}_{2} \mathrm{MoO}_{4} \cdot 2 \mathrm{H}_{2} \mathrm{O}$

$0.02 \mathrm{~g} / \mathrm{L}$

$\mathrm{Na}_{2}$ EDTA

$0.64 \mathrm{~g} / \mathrm{L}$

$1 \times$ phosphate buffer was made with distilled water and autoclaved at $121^{\circ} \mathrm{C} .200 \times \mathrm{MMN}$ salt solution was filter sterilized with $0.45 \mu \mathrm{m}$ sterile filter. $1 \mathrm{mM}$ concentration of $\mathrm{NH}_{4} \mathrm{Cl}$ was used as nitrogen source. $1 \mathrm{mM}$ final concentration of glucose or 2,4-D was used as sole carbon source. 
Appendix B: Calibration curve to spectrophotometrically monitor 2,4-D concentration

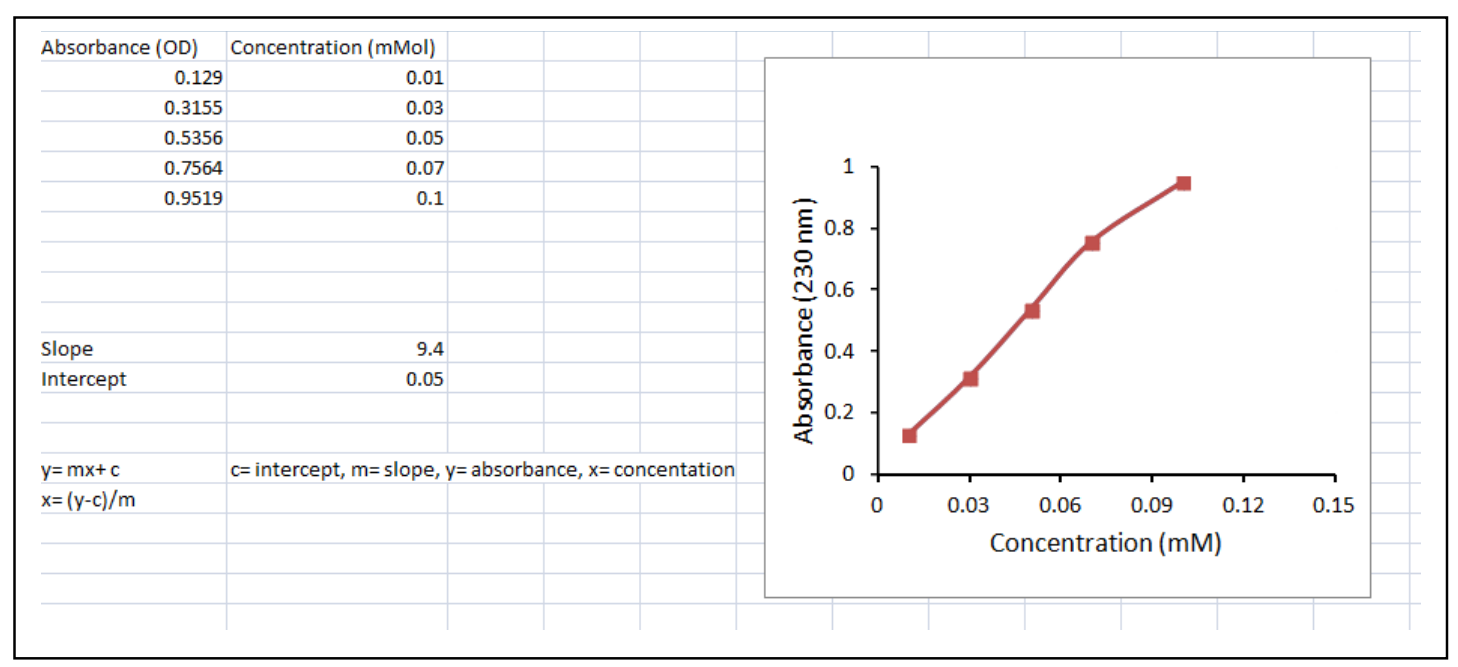




\section{CHAPTER 6: REFERENCES}

Ambujom S (2001) Studies on composition and stability of a large membered bacterial consortium degrading phenol. Microbiol Res. 156(4):293-301

Aspray TJ, Hansen SK, Burns RG (2005) A soil-based microbial biofilm exposed to 2,4-D bacterial community development and establishment of conjugative plasmid pJP4. FEMS Microbiol Ecol. 54(2):317-327

Ballerstedt H, Volkers RJM, Mars AE, Hallsworth JE, Martin dos Santos VA, Puchalka J, van Duuren J, Eggink G, Timmis KN, de Bont JAM, Wery J (2007) Genomotyping of Pseudomonas putida KT2440-based high density DNA microarrays: implications for transcriptomics studies. Appl Microbiol Biotechnol. 75(5):1133-1142

Barkay T, Liebert C, Gillman M (1993) Conjugal gene transfer to aquatic bacteria detected by the generation of a new phenotype. Appl Environ Microbiol. 59(3):807-814

Bathe S, Hausner M (2010) Plasmid-mediated bioaugmentation of wastewater microbial communities in a laboratory-Scale bioreactor. Methods Mol Biol. 599:185-200

Bathe S, Lebuhn M, Hausner M (2004a) High phylogenetic diversity of transconjugants carrying plasmid pJP4 in an activated sludge-derived microbial community. FEMS Microbiol Lett. 235(2):215-219

Bathe S, Mohan TVK, Wuertz S, Hausner M (2004b) Bioaugmentation of a sequencing batch biofilm reactor by horizontal gene transfer. Water Sci Technol. 49(11-12):337-344

Bathe S, Schwarzenbeck N, Hausner M (2005) Plasmid-mediated bioaugmentation of activated sludge bacteria in a sequencing batch moving bed reactor using pNB2. Lett Appl Microbiol. 41(3):242-247

Bathe S, Schwarzenbeck N, Hausner M (2009) Bioaugmentation of activated sludge 3chloroaniline removal with a mixed population carrying a degradative plasmid. Bioresour Technol. 100(12):2902-2909 
Beil S, Timmis KN, Pieper DH (1999) Genetic and biochemical analyses of the tec operon suggest a route for evolution of chlorobenzene degradation genes. J Bacteriol. 181(1):341-346

Bettman H, Rehm HJ (1984) Degradation of phenol by polymer entrapped microorganisms. App1 Microbiol Biotechnol. 20(5):285-290

Bjorkman J, Andersson DI (2000) The cost of antibiotic resistance from a bacterial perspective. Drug Resist Updat. 3(4):237-245.

Boon N, Goris J, Vos PD, Verstraete W, Top EM (2001) Genetic diversity among 3chloroaniline and aniline-degrading strains of the comamonadaceae. Appl Environ Microbiol. 67 (3): $1107-1113$

Bouwer EJ (1989) Transformation of Xenobiotics in Biofilms. In: Characklis WG and Wilderer PA (eds.) Structure and Function of Biofilms, pp. 251--267. New York: Wiley

Braddock JF, Ruth ML, Catterall PH (1997) Enhancement and inhibitionof microbial activity in hydrocarbon-contaminated arcticsoils: Implications for nutrient-amended bioremediation. Environ Sci Technol. 31(1):2078-2084

Brun R, Reichert P, Kunsch HR (2001) Practical identifiability analysis of large environmental simulation models. Water Resour Res. 37(4):1015-1030

Budavari S (1996) The Merck index: An Encyclopedia of Chemicals, Drugs and Biologicals. Whitehouse Station NJ: Merck

Burlage RS, Bemis LA, Layton AC, Sayler GS, Larimer F (1990) Comparative genetic organization of incompatibility group P degradative plasmids. J Bacteriol. 172(12): 6818-6825

Cerca N, Jefferson KK, Oliveira R, Pier GB, Azeredo J (2006) Comparative antibody-mediated phagocytosis of Staphylococcus epidermidis cells grown in a biofilm or in the planktonic state. Infect Immun. 74(8):4849-4855 
Chong NM, Chang HW (2009) Plasmid as a measure of microbial degradation capacity for 2,4-dichlorophenoxyacetic acid. Bioresour Technol. 100(3):1174-1179

Christensen BB, Sternberg C, Andersen JB, Eberl L, Moller S, Givskov M, Molin S (1998) Establishment of new genetic traits in a microbial biofilm community. Appl Environ Microbiol. 64 (6): $2247-2255$

Christensen BB, Sternberg C, Molin S (1996) Bacterial plasmid conjugation on semi-solid surfaces monitored with the green fluorescent protein (GFP) from Aequorea victoria as a marker. Gene 173(1 Spec No):59-65

Chudakov DM, Matz MV, Lukyanov S, Lukyanov KA (2010) Fluorescent proteins and their applications in imaging living cells and tissues. Physiol Rev. 90(3):1103-1163

Clément P, Pieper DH, González B (2001) Molecular characterization of a deletion/ duplication rearrangement in tfd genes from Ralstonia eutropha JMP134 (pJP4) that improves growth on 3chlorobenzoic acid but abolishes growth on 2,4-dichlorophenoxyacetic acid. Microbiology. 147(Pt 8): $2141-2148$

Corchero JL, Villaverde A (1998) Plasmid maintenance in Escherichia coli recombinant cultures is dramatically, steadily, and specifically influenced by features of the encoded proteins. Biotechnol Bioeng. 58(6):625-632

Crusz SA, Popat R, Rybtke MT, Camara M, Givskov M, Tolker-Neilsen T, Diggle SP, Williams P (2012) Bursting the bubble on bacterial biofilms: a flow cell methodology. Biofouling. 28(8): $835-842$

Daugherty DD, Karel SF (1994) Degradation of 2,4-Dichlorophenoxyacetic acid by Pseudomonas cepacia DB01(pRO101) in dual substrate chemostrate. Appl Environ Microbiol. 60(9):3261-3267

Davidson J (1999) Genetic exchange between bacteria in environment. Plasmid 42(2):73-91 
Dejonghe W, Goris J, Fantroussil SE, Hofte M, Vos PD, Verstraete W, Top EM. (2000) Effect of dissemination of 2,4-dichlorophenoxyacetic acid (2,4-D) degradation plasmids on 2,4-D degradation and on bacterial community structure in two different soil horizons. Appl Environ Microbiol. 66(8): 3297-3304

Dejonghe W, Boon N, Seghers D, Top E.M, Verstracete W (2001) Bioaugmentation of soils by increasing microbial richness: missing links. Environ Microbiol. 3(10):649-657

de la Cruz I, Davies I (2000) Horizontal gene transfer and the origin of species: lessons from bacteria. Trends Microbiol. 8(3):128-133

De Rore H, Top E, Houwen F, Mergeay M, Verstraete W (1994b) Evolution of heavy metal resistant transconjugants in a soil environment with concomitant selective pressure. FEMS Microbiol Ecol. 14(3):263-274

Don RH, Pemberton JM (1981) Properties of six pesticide degradation plasmids isolated from Alcaligenes paradoxus and Alcaligenes eutrophus. J Bacteriol. 145(2):681-686

Don RH, Pemberton JM (1985) Genetic and physical map of the 2-4dichlorophenoxyacetic acid degradative plasmid pJP4. J Bacteriol. 161(1):466-468

Donlan RM, Costerton JW (2002) Biofilms: survival mechanisms of clinically relevant microorganisms. Clin Microbiol Rev. 15(2):167-93

Edwards SJ, Kjellerup BV (2013) Applications of biofilms in bioremediation and biotransformation of persistent organic pollutants, pharmaceuticals/personal care products and heavy metal. Appl Microbial Biotechnol. 97(23):9909-9921

Filonov AE, Akhmetov LI, Puntus IF, Esikova TZ, Gafarov AB, Kosheleva IA, Boronin AM (2010) Horizontal transfer of catabolic plasmids and naphthalene biodegradation in open soil. Microbiology. 79(2):184-190 
Firth N, Ippen-Ihler K, Skurray R (1996) Structure and function of the F factor and mechanism of conjugation. In F. Neidhardt et al. (eds), Escherichia coli and Salmonella: Cellular and Molecular Biology, second edition, p. 2377-2401. ASM Press, Washington, D.C

Freikowski D, Winter J, Gallert C (2010) Hydrogen formation by an arsenate-reducing Pseudomonas putida, isolated from arsenic-contaminated groundwater in West Bengal, India. Appl Microbiol Biotechnol. 88(6):1363-1371

Frost LA, Koraimann G (2010) Regulation of bacterial conjugation: balancing opportunity with adversity. Future Microbiol. 5(7):1057-1071

Frost LS (1992) Bacterial conjugation: everybody's doin' it. Can J Microbiol. 38(11):1091-1096

Fujii T, Takeo M, Maeda Y (1997) Plasmid encoded genes specifying aniline oxidation from Acinetobacter YAA. Microbiology. 143(Pt 1):93-99

Fukumori F, Hausinger RP (1993) Purification and characterization of 2,4 dichlorophenoxyacetate /alpha-ketogluterate. J Biol Chem. 268(32):24311-24317

Garabrant DH, Philbert MA (2002) Review of 2,4-dichlorophenoxy acetic acid (2,4-D) epidemiology and toxicology. Crit Rev Toxicol. 32(4):233-257

Ghigo JM (2001) Natural conjugative plasmids induce bacterial biofilm development. Nature. 412(6845):442-445

Gong H, Kovar JL, Baker B, Zhang A, Cheung L, Draney DR, Corrêa IR, Xu MQ, Olive DM (2012) Near-infrared fluorescence imaging of mammalian cells and xeno graft tumors with SNAPtag. PLoS One. 7(3):e34003

Grohmann E, Muth G, Espinosa M (2003) Conjugative plasmid transfer in gram-positive bacteria. Mol Biol Rev. 67(2):277-301

Hamdi H, Benzarti S, Manusadzianas L, Aoyama I, Jedidi N (2007) Bioaugmentation and biostimulation effects on PAH dissipation and soil ecotoxicity under controlled conditions. Soil Biol Biochem. 39(8):1926-1935 
Harrison JJ, Ceri H, Turner RJ (2007) Multi metal resistance and tolerance in microbial biofilms. Nat Rev Microbiol. 5(12):928-938

Hausner M, Wuertz S (1999) High rates of conjugation in bacterial biofilms as determined by quantitative in situ analysis. Appl Environ Microbiol. 65(8): 3710-3713

Hausner M, Starek M, Bathe S (2011) Bioremediation: Plasmid-Mediated Bioaugmentation of Microbial Communities - Experience from Laboratory-Scale Bioreactors. In: Peter Wilderer (ed.) Treatise on Water Science, vol. 3, pp. 369-376 Oxford: Academic Press

Hoffman RM (2014) Imaging metastatic cell trafficking at the cellular level in vivo with fluorescent proteins. Methods Mol Biol. 1070:171-179 doi: 10.1007/978-1-4614-8244-4_12

Howard PHE (1991) "2,4-D" Handbook of Environmental Fate and Exposure Data for Organic Chemicals. pp.145-156 Lewis Publishers:(Chelsea MI)

Huang CT, Peretti SW, Bryers J D (1993) Plasmid retention and gene expression in suspended and biofilm cultures of recombinant E. coliDH5 (pMJR1750). Biotechnol Bioeng. 41: 211-220 Industry Task Force II (1999) On 2,4-D Research Date. web site: http://www.24d.org Johnsen AR, Kroer N (2007) Effects of stress and other environmental factors on horizontal plasmid transfer assessed by direct quantification of discrete transfer events. FEMS Microbiol Ecol. 59(3):718-728

Jung D, Min K, Jung J, Jang W, Kwon Y (2013) Chemical biology-based approaches on fluorescent labelling of proteins in live cells. Mol BioSyst. 9(5):862-872

Ikuma K, Gunsch CK (2012) Functionality of the TOL plasmid under varying environmental conditions following conjugal transfer. Appl Microbiol Biotechnol. 97(1):395-408

Ikuma K, Gunsch CK (2010) Effect of carbon source addition on toluene biodegradation by an $E$. coli DH5a transconjugant harboring the TOL plasmid. Biotechnol Bioeng. 107(2):269-277 
Kinkle BK, Sadowsky MJ, Schmidt EL, Koskinen WC (1993) Plasmids pJP4 and r68.45 can be transferred between populations of Bradyrhizoda in non sterile soil. Appl Environ Microbiol. 59(6):1762-1766

Krol JE, Nguyen HD, Rogers LM, Beyenal H, Krone SM, Top EM (2011) Increased transfer of a multidrug resistance plasmid in Escherichia coli biofilms at the air-liquid interface. Appl Environ Microbiol. 77(15):5079-5088

Krol JE, Wojtowicz AJ, Rogers LM, Heuer H, Smalla K, Krone SM, Top EM (2013) Invasion of Escherichia coli biofilms by antibiotic resistance plasmids. Plasmid 70(1):110-119

Kurland CG, Canback B, Berg OG (2003) Horizontal gene transfer: a critical view. Proc Natl Acad Sci U S A. 100(7): 9658-9662

Kues U, Stahl U (1989) Replication of plasmids in gram negative bacteria. Microbiol Rev. 53(4): $491-516$

Leisinger T (1983) Microorganism and xenobiotic compounds. Experientia. 39 (11): 1183-1191

Laemmli CM, Leveau JHJ, Zehnder AJB, van der Meer JR (2000) Characterization of a second tfd gene cluster for chlorophenol and chlorocatechol metabolism on plasmid pJP4 in Ralstonia eutropha JMP134 (pJP4). J Bacteriol. 182(15): 4165-4172.

Leveau JH, van der Meer JR (1997) Genetic characterization of the insertion sequence ISJP4 on plasmid pJP4from Ralstonia eutropha JMP134. Gene 202(1-2): 103-114.

Licht TR, Christensen BB, Krogfelt KA, Molin S (1999) Plasmid transfer in the animal intestine and other dynamic bacterial populations: the role of community structure and environment. Micrbiol. 145 (Pt 9):2615-2622

Lilley AK, Bailey MJ (1997) The acquisition of indigenous plasmids by a genetically marked pseudomonad population colonizing the sugar beet phytosphere is related to local environmental conditions. Appl Environ Microbiol. 63(4):1577-1583.

Lili LN, Britton NF, Feil EJ (2007) The persistence of parasitic plasmids. Genetics. 177: 399-405 
Lipthay JR, Aamand J, Barkay T (2001) Expression of $t f d A$ genes in aquatic microbial communities during acclimation to 2, 4-dichlorophenoxyacetic acid. FEMS Microbiol Ecol. 40(3): 205-214

Lisenbee CS, Karnik SK, Trelease RN (2003) Over expression and mislocalization of a tailanchored GFP redefines the identity of paroxysmal ER. Traffic 4(7):491-501

Liu S, Suflita JM (1993) Ecology and evolution of microbial populations for bioremediation. Trends Biotechnol. 11(8): 344-352

Lorenz MG, Wackernagel W (1994) Bacterial gene transfer by natural genetic transformation in the environment. Microbiol Rev. 58(30):563-602

Ma H, Bryers JD (2012) Non-invasive determination of conjugate transfer of plasmids bearing antibiotic-resistance genes in biofilm-bound bacteria: effects of substrate loading and antibiotic selection. Appl Microbial Biotechnol. 97(1):317-328

Ma H, Katzenmeyer KN, Bryers JD (2013) Non-invasive in situ monitoring and quantification of TOL plasmid segregational loss within Pseudomonas putida biofilms. Biotechnol Bioeng. 110(11):2949-2958

Macrina FL, Archer G L (1993) Conjugation and broad host range plasmids in streptococci and staphylococci. pp.319-339. In D. B. Clewell (ed.), Bacterial conjugation. Plenum Press, New York, N.Y

Madsen JS, Burmolle M, Hansen LH, Sorensen SJ (2012) The interconnection between biofilm formation and horizontal gene transfer. FEMS Immunol Med Microbial. 65(2):183-195

Madsen JS, Burmolle M, Sorensen SJ (2013) A spatiotemporal view of plasmid loss in biofilms and planktonic cultures. Biotechnol Bioeng. 110(12):3071-3074

Matz MV, Fradkov AF, Labas YA, Savitsky AP, Zaraisky AG, Markelov ML, Lukyanov SA (1999) Fluorescent proteins from non bioluminescent Anthozoa species. Nat Biotechnol. 17(12): 969-973 
Merkey B, Seoane J, Yankelevich T, Dechesne A, Sternberg C, Smets BF (2011) An individual based approach to explain plasmid invasion in bacterial populations. FEMS Microbiol Ecol. 75(1):17-27

Miyawaki A, Nagai T, Mizuno H (2003) Mechanisms of protein fluorophore and engineering. Curr Opin Chem Biol. 7(5): 557-562

Mollin S, Tolker-Nielsen (2003) Involvement of bacterial migration in the development of complex multicellular structures in Pseudomonas aeruginosa biofilms. 50(1):61-68

Moreau MJ, Morin I, Schaeffer PM (2010) Quantitative determination of protein stability and ligand binding using a green fluorescent protein reporter system. Mol. BioSyst. 6(7):1285-1292

Morrison WD, Miller RV, Saylerg S (1978) Frequency of F116-mediated transduction of Pseudomonas aeruginosa a freshwater environment. Appl . Environ. Microbiol. 36(5):724-730

Mrozik A, Piotrowska-Seget Z (2009) Bioaugmentation as a strategy for cleaning up of soils contaminated with aromatic compounds. Microbiol Res. 165(5):363-375

Mulligan ME, McClure WR (1986) Analysis of the occurrence of promoter-sites in DNA. Nucleic Acids Res. 14(1):109-126

Munro IC, Carlo GL, Orr JC, Sund K, Wilson RM, Kennepohl E, Lynch B, Jablinske M, Lee N (1992) A comprehensive, integrated review and evaluation of the scientific evidence relating to the safety of the herbicide 2,4-D. J Am Coll Toxicol. 11(5):559-664

Muto A, Osawa S (1987) The guanine and cytosine content of genomic content DNA and bacterial evolution. Proc Natl Acad Sci U S A. 84(1):166-169

Nancharaiah YV, Wattaiu P, Wuertz S, Bathe S, Mohan SV, Wilderer PA, Hausner M (2003) Dual labelling of Pseudomonas putida with fluorescent proteins for in situ monitoring of conjugal transfer of the TOL plasmid. Appl Environ Microbiol. 69(8):4846-4852

Nancharaiah YV, Venugopalan VP, Wuertz S, Wilderer PA, Hausner M (2005) Compatibility of the green fluorescent protein and a general nucleic acid stain for quantitative description of a Pseudomonas putida biofilm. J Microbiol Methods. 60(2):179-187 
Nancharaiah YV, Joshi HM, Hausner M, Venugopalan VP (2008) Bioaugmentation of aerobic microbial granules with Pseudomonas pudita carrying TOL plasmid. Chemosphere. 71(1): 30 - 35

Neilson AH (1996) An environmental prospective on the biodegradation of organochlorine xenobiotics. Int Biogeter Biodegr. 37(1-2):3-12

Neilson JW, Josephson KL, Pillai SD, Pepper IL (1992) Polymerase chain reaction and gene probe detection of the 2,4-dichlorophenoxyacetic acid degradation plasmid, pJP4. Appl Environ Microbiol. 58(4): 1271-1275

Neilson JW, Josephson KL, Pepper IL, Arnold RB, Giovanni GDD, Sinclair NA (1994) Frequency of horizontal gene transfer of a large catabolic plasmid, pJP4 in soil. Appl Environ Microbiol. 60(11): 4053-4058

Newby DT, Gentry TJ, Pepper IL (2000) Comparison of 2,4-dichlorophenoxyacetic acid degradation and plasmid transfer in soil resulting from bioaugmentation with two different pJP4 donors. Appl Environ Biotechnol. 66(8): 3399-3407

Newby DT, Pepper IL (2002) Dispersal of plasmid pJP4 in unsaturated and saturated 2,4dichlorophenoxyacetic acid contaminated soil. FEMS Microbiol Ecol. 39 (2): 157-164

Norman A, Hansen LH, Sorensen SJ (2009) Conjugative plasmids: vessels of the communal gene pool. Philos Trans R Soc Lond B Biol Sci. 364(1527):2275-2289

Nojiri H, Shintani M, Omori T (2004) Divergence of mobile genetic elements involved in the distribution of xenobiotic-catabolic capacity. Applied Microbiol Biotechnol. 64(2):154 -174

O’Connell HA, Niu C, Gilbert ES (2006) Enhanced high copy number plasmid maintenance and heterologous protein production in an Escherichia coli biofilm. Biotechnol Bioeng. 97(3):439-446 Pamp SJ, Gjermansen M, Johansen HK, Tolker-Nielsen T (2008) Tolerance to the antimicrobial peptide colistin in Pseudomonas aeruginosa biofilms is linked to metabolically active cells, and depends on the pmr and mexABoprM genes. Mol Microbiol. 68(1):223-240 
Pemberton JM, Fisher PR (1977) 2,4-D plasmids and persistence. Nature. 268(5622): 732-733

Pemberton JM, Schmidt R (2001) Catabolic Plasmid. Encyclopedia of Life Sciences, John Wiley \& Sons Ltd p: 1-9

Pérez-Pantoja D, Guzmán L, Manzano M, Pieper DH, González B (2000) Role of tfdCIDIEIFI and tfdDIICIIEIIFII gene modules in catabolism of 3-chlorobenzoate by Ralstonia eutropha JMP134 (pJP4). App1 Environ Microbiol. 66(4):1602-1608

Pérez-Pantoja D, Ledger T, Pieper DH, González B (2003) Efficient turnover of chlorocatechols is essential for growth of Ralstonia eutropha JMP134 (pJP4) in 3-chlorobenzoic acid. J Bacteriol. 185(5):1534-1542

Peterson EM, Harris JM (2010) Quantitative detection of single molecules in fluorescence microscopy images. Anal Chem. 82(1):189-196

Plumeier I, Pérez-Pantoja D, Heim S, González B, Pieper DH (2002) The importance of different $t f d$ genes during the degradation of chloroaromatics by Ralstonia eutropha JMP134. J Bacteriol. 184(15): 4054-4064

Ponciano JM, De Gelder L, Top EM, Joyce P (2007) The population biology of bacterial plasmids: a hidden Markov model approach. Genetics. 176(2):957-968

Postelnik F (2012) Examining plasmid transfer of pJP4 in a mixed community biofilm formed in a microcosm simulating a porous aquifer. M.Sc. Thesis, Ryerson University; Toronto, Canada Quan X, Tang H, Xiong W, Yang Z (2010) Bioaugmentation of aerobic sludge granules with a plasmid donor strain for enhanced degradation of 2,4-dichlorophenoxyacetic acid. J Hazard Mater. 179(1-3):1136-1142

Quan X, Tang H, Ma J (2011) Effects of gene augmentation on the removal of 2,4dichlorophenoxyacetic acid in biofilm reactor under different scales and substrate conditions. J Hazard Mater. 185(2-3):689-695 
Qureshi N, Annous BA, Ezeji TC, Karcher P, Maddox IS (2005) Biofilm reactors for industrial bioconversion processes: employing potential of enhanced reaction rates. Microb Cell Fact. p:4-24

Ramage G, Martinez JP, Lopez-Ribot JL (2006) Candida biofilms on implanted biomaterials: a clinically significant problem. FEMS Yeast Res. 6(7):979-986

Reisner A, Holler BM, Molin S, Zechner EL (2006) Synergistic effects in mixed E. coli biofilms: conjugative plasmid transfer drives biofilm expansion. J Bacteriol. 188(10):3582-3588

Reisner A, Wolinski H, Zechner EL (2012) In situ monitoring of IncF plasmid transfer on semisolid agar surfaces reveals a limited invasion of plasmids in recipient colonies. Plasmid. 67(2):155161

Reitzel LA, Tuxen N, Ledin A, Bjerg PL (2004) Can degradation productsbe used as documentation for natural attenuation of phenoxyacids in groundwater? Environ Sci Technol. $38(2): 457-467$

Rensing C, Newby DT, Pepper IL (2002) The role of selective pressure and selfish DNA in horizontal gene transfer and soil microbial community adaptation. Soil Biol Biochem. 34(3):285-96 Ricci JCD, Hernandez ME (2000) Plasmid effects on Escherichia coli metabolism. Crit Rev Biotechnol. 20(2):79-108

Rozkov A, Avignone-Rossa CA, Ertl PF, Jones P, O’Kennedy RD, Smith JJ, Dale JW, Bushell ME (2004) Characterization of the metabolic burden on Escherichia coli DH1 cells imposed by the presence of a plasmid containing a gene therapy sequence. Biotechnol Bioeng. 88(7):909-15

Russel JB, Cook GM (1995) Energetics of bacterial growth: balance of anabolic and catabolic reactions. Microbiol Rev. 59(1): 48-62

Sayler GS, Hooper SW, Layton AC, King JMH (1990) Catabolic plasmids of environmental and ecological significance. Microb Ecol. 19(1):1 -20

Schühle K, Jahn M, Ghisla S, Fuchs G (2001) Two similar gene clusters coding for enzymes of a new type of aerobic 2-aminobenzoate (anthranilate) metabolism in thebacterium Azoarcus evansii. J Bacteriol. 183(18):5268-5278 
Seitz P, Blokesch M (2013) Cues and regulatory pathways involved in natural competence and transformation in pathogenic and environmental gram negative bacteria. FEMS Microbiol Rev. $37(3): 336-363$

Seoane J, Sin G, Lardon L, Gernaey KV, Smets BF (2010) A new extant respirometric assay to estimate intrinsic growth parameters applied to study plasmid metabolic burden. Biotechnol Bioeng. 105(1):141-149

Shamsad F (2012) Transfer of the catabolic plasmid pJP4 in bacterial biofilms in lab-scale continuous flow through cells. M.Sc. Thesis, Ryerson University; Toronto, Canada

Sharp RR, Bryers JD, Jones WG (1998) Activated and stability of a recombinant plasmid-borne TCE degradative pathway in biofilm cultures. Biotech Biogeng. 59(3):318-327

Siddique T, Okeke BC, Arshad M, Frankenberger WT (2002) Temperature and pH effects on biodegradation of hexachlorocycohexane isomers in water and a soil slurry. J Agric Food Chem. 50(18):5070-5076

Simonsen L (1990) Dynamics of plasmid transfer on surfaces. J Gen Microbiol. 136(6):1001-1007

Singleton I (1994) Microbial metabolism of xenobiotics: fundamental and applied research. J Chem Technol Biot. 59(1):9-23

Slater FR, Bailey MJ, Tett AJ, Turner SL (2008) Progress towards understanding the fate of plasmids in bacterial communities. FEMS Microbial Ecol. 66(1):3-13

Smillie C, Garcillin-Barcia MP, Francia MV, Rocha EPC, de la Cruz F (2010) Mobility of plasmids. Microbiol Mol Biol Rev. 74(3):434-452

Sorensen SJ, Bailey M, Hansen LH, Kroer N, Wuertz S (2005) Studying plasmid horizontal transfer in situ: a critical review. Nat Rev Microbiol. 3(9):700-710

Spliid NH, Køppen B (1998) Occurrence of pesticides in Danish shallow ground water. Chemosphere. 37(7):1307-1316 
Stadler C, Rexhepaj E, Singan VR, Murphy RF, Pepperkok R, Uhlén M, Simpson JC, Lundberg E (2013) Immunofluorescence and fluorescent-protein tagging show high correlation for protein localization in mammalian cells. Nat Methods.10(4):315-323

Stanisich V, Bennett P (1976) The properties of hybrids formed between the P-group plasmid RP1 and various plasmids from Pseudomonas aeruginosa. Mol Gen Genet. 149(2):217-223

Stephenson JR, Warnes A (1996) Release of genetically modified microorganisms into the environment. J. Chem. Tech. Biotechnol. 65(1):5-14

Stoodley LH, Costerton JW, Stoodly P (2004) Bacterial biofilms: from the natural environment to infectious diseases. Nat Rev Microbiol. 2(2): 95-108

Stoodley P, Sauer K, Davies DG, Costerton JW (2002) Biofilms as complex differentiated communities. Annu Rev of Microbiol. 56:187-209

Sturman PJ, Stewart PS, Cunningham AB, Bouwer EJ Wolframe JH (1995) Engineering scaleup of in situ bioremediation processes: a review. J Contam Hydrol. 19(3):171-203

Top EM, Holben WE, Forney LJ (1995) Characterization of diverse 2,4-dichlorophenoacetic acid degradative plasmids isolated from soil by complementation. Appl Environ Microbiol. 61(5): $1691-1698$

Top EM, Springael D, Boon N (2002) Catabolic mobile genetic elements and there potential use in bioaugmentation of polluted soils and waters. FEMS Microbiol Ecol. 42(2):199-208

Top EM, Moenne-Loccoz, Pembroke T, Thomas CM (2000) Phenotypic Traits Conferred By Plasmids. In: The Horizontal Gene Pool Bacterial Plasmids and Gene Spread (Thomas C.M., Ed), pp.249-85. Harvard Academic Publishers

Top EM, Springael D (2003) The role of mobile genetic elements in bacterial adaptation to xenobiotic organic compounds. Curr Opin Biotechnol. 14(3):262-269 
Thomas CM (1989) Promiscuous Plasmids of Gram-negative Bacteria. Academic Press: London

Trefault N, De la lglessia R, Molina AM, Manzano M, Ledger T, Perez-Pantoja D, Sanchez MA, Stuardo M, Gonzalez B (2004) Genetic organization of the catabolic plasmid pJP4 from Ralstonia eutropha JMP134 (pJP4) reveals mechanisms of adaptation of chloroaromatic pollutants and evolution of specialized chloroaromatic degradation pathways. Environ Microbiol. 6(7):655-668

Trevors JT, Barkay T, Bourquin AW (1986) Gene transfer among bacteria in soil and aquatic environments: a review. Can J Microbiol. 33(3):191-198

Tschape H (1994) The speed of plasmids as a function of bacterial adaptability. FEMS Microbio Ecol. 15(1-2):23-32

Tsutsui H, Anami Y, Matsuda M, Inoue D, Sei K, Soda S, Ike M (2013) Plasmid-mediated bioaugmentation of sequencing batch reactors for enhancement of 2,4-dichlorophenoxyacetic acid removal in wastewater using plasmid pJP4. Biodegradation 24(3):343-352

Tsutsui H, Anami Y, Matsuda M, Inoue D, Sei K, Soda S, Ike M (2010) Transfer of plasmid pJP4 from Escherichia coli and Pseudomonas putida to bacteria in activated sludge developed under different retention times. J Biosci Bioeng. 110(6): 684 -689

Tsuda M, Tan HM, Nishi A, Furukawa (1999) Mobile catabolic genes in bacteria. J Biosci Bioeng. 87(4): $401-410$

Tuschl H, Schwab C (2003) Cytotoxic effect of the herbicide 2,4dichlorophenoxyacetic acid in HepG2 cells, Food Chem Toxicol. 41(3): 385-393

van Elsas JD, Fry JC, Hirsch P, Molin S (2000) Ecology of Plasmid Transfer and Spread in the Horizontal Gene Pool. Bacterial Plasmids and Gene Spread (Thomas, C.M., Ed.) p:175-206 van Elsas JD, Baiely MJ (2002) The ecology of transfer of mobile genetic elements FEMS Microbio Ecol. 42(2):187-197 
van Limbergen H, Top EM, Verstraete W (1998) Bioaugmentation in activated sludge: current features and future prospective. Appl Microbiol Biotechnol. 50(1):16-23

Vedler E, Koiv V, Heinaru A (2000) Analysis of the 2,4-dichlorophenoxyacetic acid degradative plasmid pEST4011 of Achromobacter xylosoxidans subsp. denitrificans strain EST4002. Gene 255: $281-288$

Venugopalan VP, Kuehn M, Hausner M, Springael D, Wilderer PA, Wuertz S (2005) Architecture of a nascent Sphingomonas sp. biofilm under hydrodynamic conditions. Appl Environ Microbiol. 71(5): 2677-2686

Vogel TM (1996) Bioaugmentation as a soil bioremediation approach. Curr Opin Biotechnol. 7(3):

$311-316$.

Watnick P, Kolter R (2000) Biofilm, city of microbes. J Bacteriol. 182(10): 2675-2679

Werner D, Garratt JA, Pigott G (2012) Sorption of 2,4-D and other phenoxy herbicides to soils, organic matter and minerals. J Soils Sediments. 13(1):129-139

Whitchurch CB, Tolker-Neilson T, Ragas PC, Kattick JS (2002) Extracellular DNA required for bacterial biofilm formation. Science. 295(5559):1487-1498

Widdel F (2007) Theory and Measurement of Bacterial Growth. website http://www.mpibremen.de/Binaries/Binary13037/Wachstumsversuch.pdf

Willetts N, Wilkins B (1984) Processing of plasmid DNA during bacterial conjugation. Microbiol Rev. 48(1): 24-41

Willey JM, Sherwood LM, Woolverton CJ (2011) Prescoott's Microbiology. Eighth edition, p. 378-385, McGraw-Hill Companies Inc., Toronto

Wolfaardt GM, Lawrence JR, Headley JV, Roberts RD Caldwell DE (1994) Microbial exopolymers provide a mechanism for bioaccumulation of contaminants. Microb Ecol. 27(3):279291 
Wuertz S, Hendrickx L, Kuehn M, Rodenacker K, Hausner M (2001) In situ quantification of gene transfer in biofilms. Methods Enzymol. 336:129-143

Wyndham RC, Cashore AE, Nakatsu CH, Peel MC (1994) Catabolic transposons. Biodegradation. $5(3-4): 323-342$ 